$(200)$

WRi

$120.94-4212$

Water-Resources Investigations Report 94-4212

\title{
HYDROGEOLOGY, GROUND-WATER QUALITY, AND SOURCE OF GROUND WATER CAUSING WATER-QUALITY CHANGES IN THE DAVIS WELL
} FIELD AT MEMPHIS, TENNESSEE

U.S. GEOLOGICAL SURVEY MAY $16 \quad 1995$

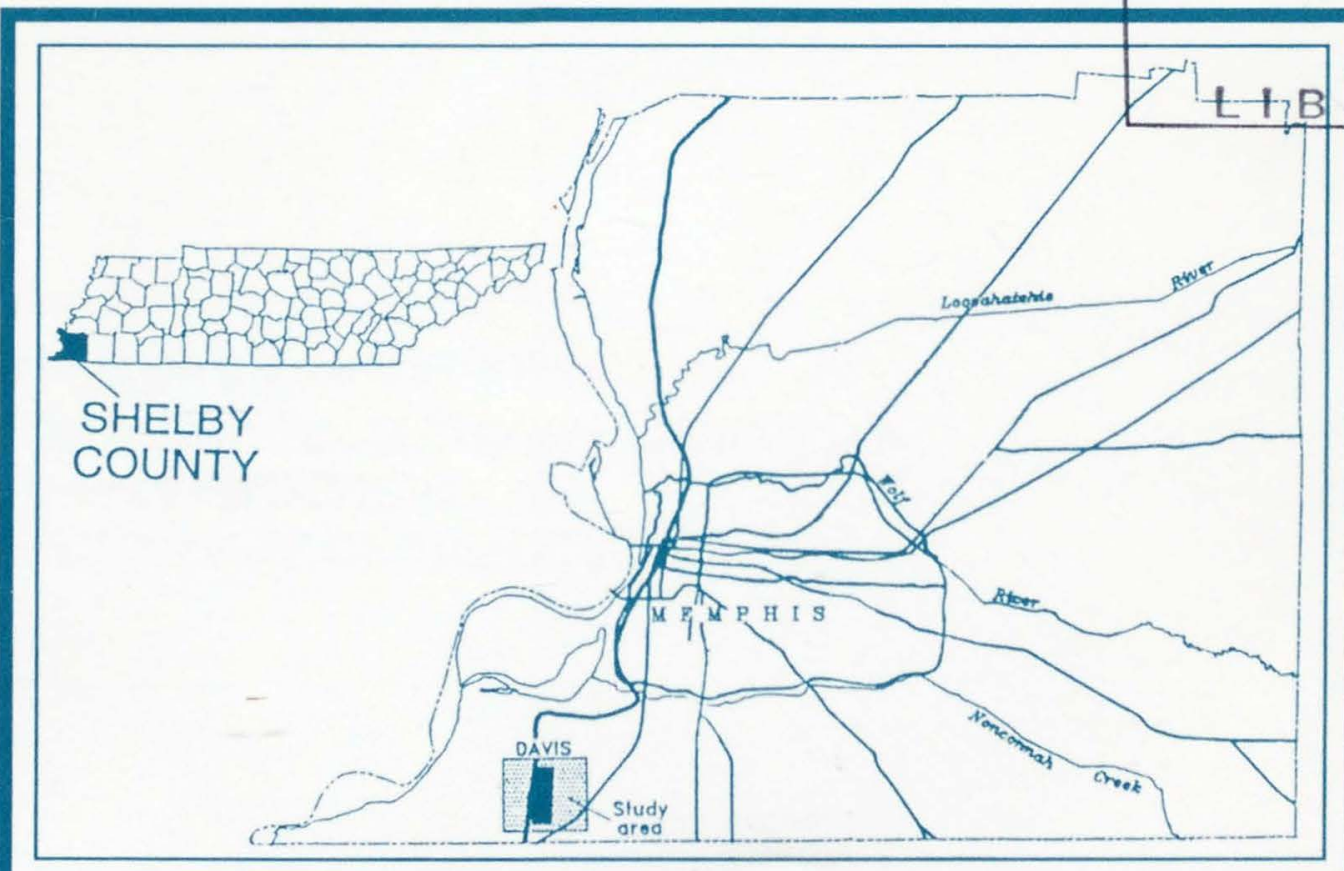

Prepared by the

U.S. GEOLOGICAL SURVEY

in cooperation with the CITY OF MEMPHIS, MEMPHIS LIGHT, GAS

AND WATER DIVISION and THE UNIVERSITY OF MEMPHIS

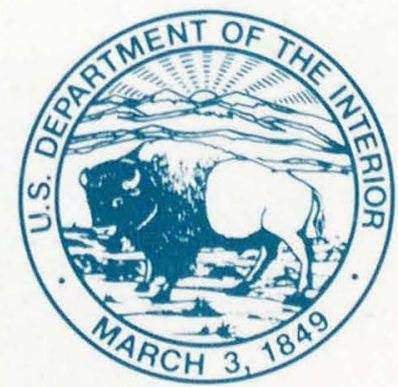


Cover illustration. Memphis, Tennessee, area and location of the Davis well field study area. (See figure 1, page 4.) 


\section{HYDROGEOLOGY, GROUND-WATER QUALITY, AND SOURCE OF GROUND WATER CAUSING WATER-QUALITY CHANGES IN THE DAVIS WELL FIELD AT MEMPHIS, TENNESSEE}

By William S. Parks, June E. Mirecki, and James A. Kingsbury

U.S. GEOLOGICAL SURVEY

Water-Resources Investigations Report 94-4212

Prepared in cooperation with the CITY OF MEMPHIS, MEMPHIS LIGHT, GAS

AND WATER DIVISION and THE UNIVERSITY OF MEMPHIS

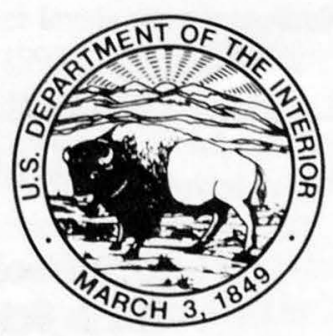

Memphis, Tennessee 


\section{U.S. DEPARTMENT OF THE INTERIOR \\ BRUCE BABBITT, Secretary \\ U.S. GEOLOGICAL SURVEY \\ Gordon P. Eaton, Director}

Any use of trade, product, or firm name in this report is for identification purposes only and does not constitute endorsement by the U.S. Geological Survey.

For additional information write to:

District Chief

U.S. Geological Survey

810 Broadway, Suite 500

Nashville, Tennessee 37203
Copies of this report can be purchased from:

U.S. Geological Survey

Earth Science Information Center

Open-File Reports Section

Box 25286, MS 517

Denver Federal Center

Denver, CO 80225-0425 


\section{CONTENTS}

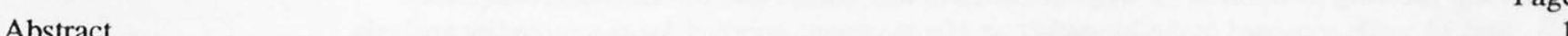

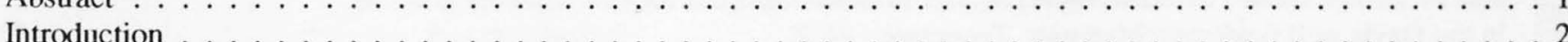

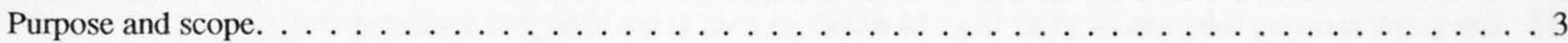

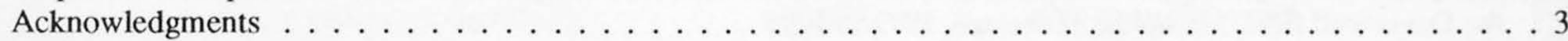

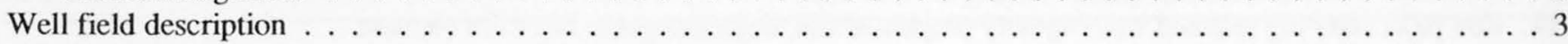

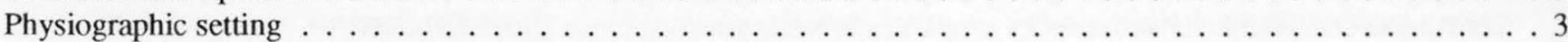

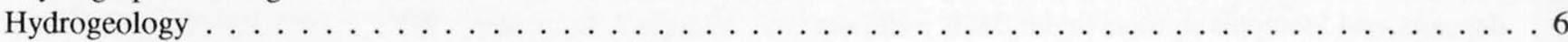

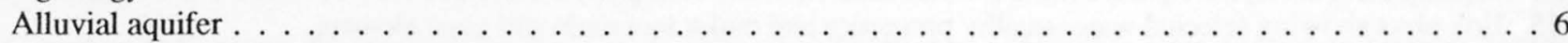

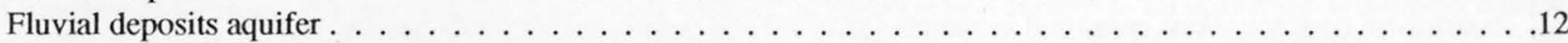

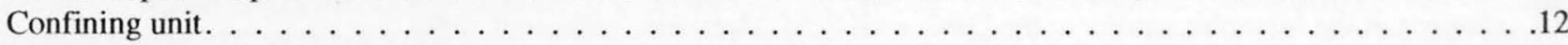

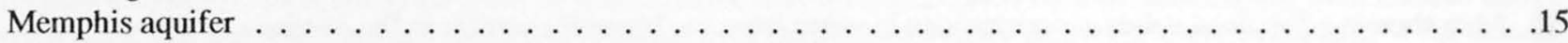

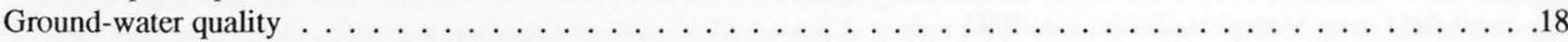

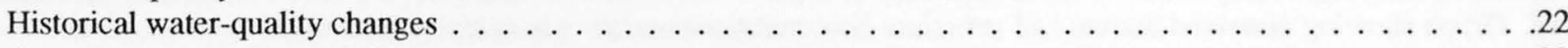

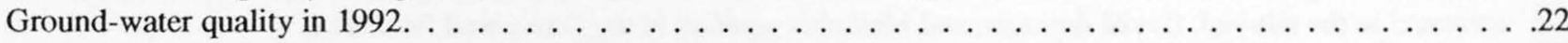

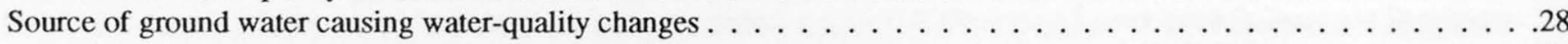

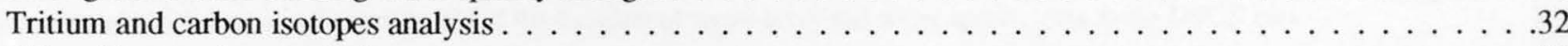

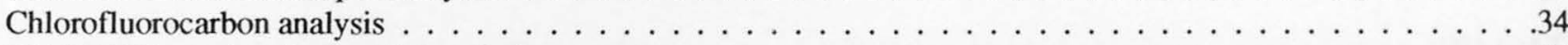

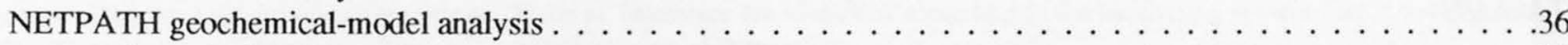

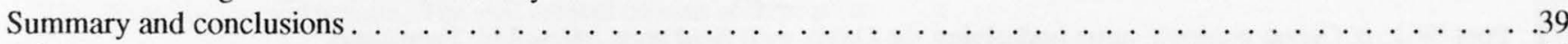

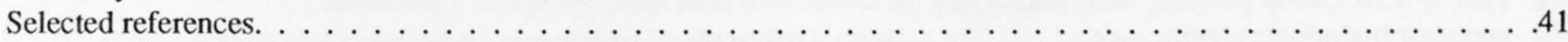

Appendix 1: Construction diagrams, gamma-ray logs, and lithology from test holes for 12 wells

installed in the alluvium and fluvial deposits in the Davis well field area, Memphis, Tennessee . . . . . . . . . . .43

Appendix 2: Selected water-quality properties and constituent concentrations analyzed by

Memphis Light, Gas and Water Division in samples from production wells screened in the

Memphis aquifer at the Davis well field, Memphis, Tennessee

\section{FIGURES}

1. Map showing major physiographic subdivisions in the Memphis area and location of principal Memphis Light, Gas and Water Division well fields and the study area . . . . . . . . . . . 4

2. Map showing location of the study area, the 14 production wells, pumping station, and water-supply treatment plant within the Davis well field, Memphis, Tennessee . . . . . . . . . . . . 5

3. Hydrogeologic sections A - A' and B - B' through the Davis well field area, Memphis,

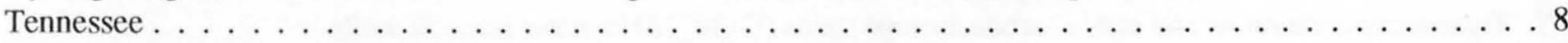

4. Map showing location of wells in which water levels were measured in the Davis well field area, Memphis, Tennessee, September 1993

5. Hydrographs showing water levels recorded in well A2 screened in the alluvial aquifer and stage of the Mississippi River at Memphis, Tennessee, October 1992 to October 1993.

6. Map showing altitude of potentiometric surface in the alluvial and fluvial deposits aquifers in the Davis well field area, Memphis, Tennessee, September 1993.

7. Hydrographs showing water levels recorded in wells Sh:J-172, F419, and F414 screened in the fluvial deposits aquifer, Memphis, Tennessee, October 1992 to October 1993

8. Map showing altitude of erosional surface at the top of the confining unit or Memphis aquifer beneath the alluvial and fluvial deposits aquifers in the Davis well field area, Memphis, Tennessee .

9. Hydrographs showing water levels recorded in wells F414 and F419 screened in the fluvial deposits aquifer, Memphis, Tennessee, July to September 1993, and weekly periods when nearby production wells M414 and M419 were pumped. 
10. Hydrographs showing water levels recorded in wells Sh:J-1 and Sh:J-140 screened in the Memphis aquifer, Memphis, Tennessee, October 1992 to October $1993 \ldots \ldots$. . . . . . . . . . . . 19

11. Map showing altitude of potentiometric surface of the Memphis aquifer, in the Davis well field area, Memphis, Tennessee, September 1993 . . . . . . . . . . . . . . . . . . . . . . . 20

12. Map showing location of 12 wells screened in the alluvial and fluvial deposits aquifers and 14 wells screened in the Memphis aquifer that were sampled for water-quality analysis in the Davis well field area, Memphis, Tennessee . . . . . . . . . . . . . . . . . . . . 21

13. Bar graph showing hardness of water from 14 wells screened in the Memphis aquifer at the Davis well field, Memphis, Tennessee, 1972 to $1991 \ldots \ldots \ldots \ldots$. . . . . . . . . . . . . 23

14. Box plots showing selected water-quality properties and major inorganic and trace element constituent concentrations measured in samples from wells screened in the alluvial, fluvial deposits, and Memphis aquifers in the Davis well field area, Memphis, Tennessee, 1992 . . . . . . . . . . . . . 27

15. Box plots showing selected water-quality properties and major inorganic and trace element constituent concentrations measured in samples affected and unaffected by water-quality changes in the Memphis aquifer in the Davis well field, Memphis, Tennessee, 1992

16. Map showing dissolved solids concentrations in water from the Memphis aquifer in the Davis

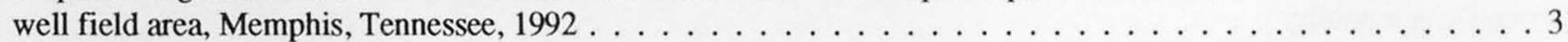

17. Graph showing dissolved barium and strontium concentrations analyzed in samples from wells screened in the alluvial, fluvial deposits, and Memphis aquifers in the Davis well field area, Memphis, Tennessee, $1992 \ldots \ldots \ldots \ldots \ldots \ldots \ldots \ldots \ldots \ldots \ldots$

\section{TABLES}

1. Post-Wilcox Group geologic units underlying the Davis well field area, Memphis, Tennessee,

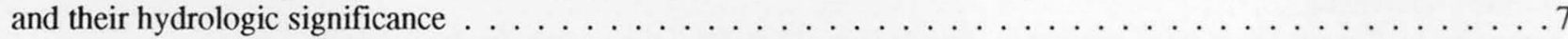

2. Water levels measured in 33 wells screened in the alluvial, fluvial deposits, and Memphis aquifers in the Davis well field area, Memphis, Tennessee . . . . . . . . . . . . . . . . . 9

3. Water-quality properties and selected major inorganic and trace element constituent concentrations analyzed by the U.S. Geological Survey in samples from well M404 screened in the Memphis aquifer at the Davis well field, Memphis, Tennessee, 1980 to 1991.

4. Water-quality properties and major inorganic constituent concentrations in samples from 26 wells screened in the alluvial, fluvial deposits, and Memphis aquifers in the Davis well field area, Memphis, Tennessee, 1992.

5. Trace inorganic constituent concentrations in water from 26 wells screened in the alluvial, fluvial deposits, and Memphis aquifers in the Davis well field area, Memphis, Tennessee, 1992 . . . . . . . . . 26

6. Selected water-quality properties and major inorganic and trace element constituent concentrations used to determine unaffected and affected wells screened in the Memphis aquifer in the Davis well field, Memphis, Tennessee, 1992. . . . . . . . . . . . .

7. Tritium concentrations and stable carbon-isotope ratios (C13/C12) in water from 22 wells screened in the alluvial, fluvial deposits, and Memphis aquifers in the Davis well field area, Memphis, Tennessee, 1992-93 . . . . . . . . . . . . . . . . . . . . . . . . 30

8. Chlorofluorocarbon concentrations in water from six wells screened in the alluvial, fluvial deposits, and Memphis aquifers in the Davis well field area, Memphis, Tennessee, 1993 . . . . . . . . . . . . 34

9. Selected major inorganic and trace element constituent concentrations used for NETPATH geochemical analysis at the Davis well field, Memphis, Tennessee . . . . . . . . . . . . . . . . 37

10. NETPATH geochemical model constraints and phases used to simulate mixing of alluvial aquifer water (well A3) with unaffected Memphis aquifer water (well M404) to obtain affected Memphis aquifer water (wells M419 and M421), using dissolved chloride as a

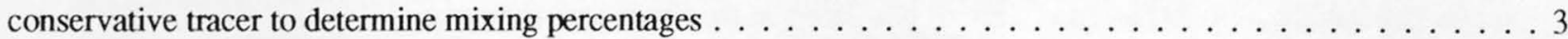

11. NETPATH geochemical model constraints and phases used to simulate mixing of alluvial aquifer water (well A3) with unaffected Memphis aquifer water (well M404) to obtain affected Memphis aquifer water (wells M419 and M421), using selected major inorganic and trace element constituents to determine mixing percentages $\ldots \ldots \ldots \ldots \ldots \ldots \ldots \ldots \ldots$ 


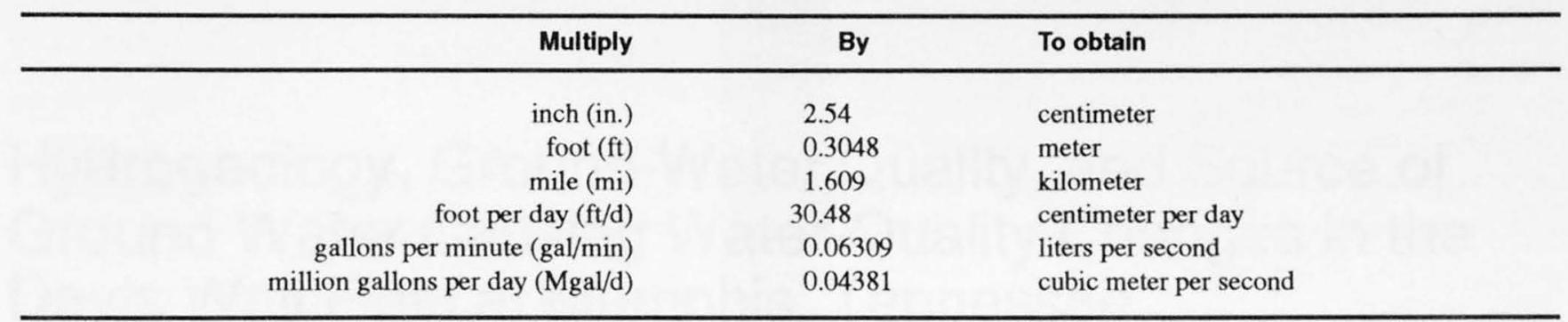

Sea level: In this report "sea level" refers to the National Geodetic Vertical Datum of 1929--a geodetic datum derived from a general adjustment of the first-order level nets of the United States and Canada, formerly called Sea Level Datum of 1929.

Well-Numbering Systems: For brevity in this report, wells are assigned project or map numbers to aid in discussions involving comparisons of data as related to well locations and aquifers in which the wells are screened. Five wells installed in the Mississippi Alluvial Plain are assigned numbers $1-5$ preceded by the letter "A" to indicate the alluvial aquifer. Seven wells (and one existing well) installed near Memphis Light, Gas and Water Division (MLGW) production wells are assigned well-lot numbers preceded by the letter "F" to indicate the fluvial deposits aquifer. Fourteen production wells in the Davis well field were assigned MLGW well numbers (the same as the welllot number) preceded by the letter " $\mathrm{M}$ " to indicate the Memphis aquifer.

In tables 2 through 6 in this report, both the project or map numbers and the U.S. Geological Survey (USGS), Tennessee District, well numbers are given for cross reference to aid in the location of water-level and water-quality data in the USGS files.

Tennessee District well-numbering system: Wells in Tennessee are identified according to the numbering system that is used by the USGS, Water Resources Division. The well number consists of three parts:

(1) an abbreviation of the name of the county in which the well is located;

(2) a letter designating the $71 / 2$-minute topographic quadrangle on which the well is plotted; quadrangles are lettered from left to right across the county beginning in the southwest corner of the county; and

(3) a number generally indicating the numerical order in which the well was inventoried.

For example, Sh:H-17 indicates that the well is located in Shelby County on the "H" quadrangle and is identified as well 17 in the numerical sequence. 


\title{
Hydrogeology, Ground-Water Quality, and Source of Ground Water Causing Water-Quality Changes in the Davis Well Field at Memphis, Tennessee
}

\author{
By William S. Parks, June E. Mirecki, and James A. Kingsbury
}

\section{ABSTRACT}

An investigation was conducted by the U.S. Geological Survey from 1992 to 1994 to collect and interpret hydrogeologic and water-quality data to determine the source of ground water causing water-quality changes in water from wells screened in the Memphis aquifer in the Davis well field at Memphis, Tennessee. Water-quality changes in aquifers used for water supply are of concern because these changes can indicate a potential for contamination of the aquifers by downward leakage from near-surface sources.

The water-quality changes at the Davis well field were detected by Memphis Light, Gas and Water Division, which has periodically sampled and analyzed water from many of the 14 production wells since the well field began operation in 1971. Memphis Light, Gas and Water Division analyzed the water samples primarily for hardness, alkalinity, chloride, sulfate, and iron. Results of these analyses and results of more recent (1992) analyses of water samples by the U.S. Geological Survey indicate that the quality of water from eight of the production wells has changed since the well field began operation. For example, from 1972 to 1991 , hardness of water from one well has increased from 90 to 292 milligrams per liter (224 percent).

The confining unit, which separates the fluvial deposits aquifer from the Memphis aquifer in the area of the well field, is relatively thick and contains many clay layers. However, a test hole drilled for one of five shallow wells installed in the alluvial aquifer in the Mississippi Alluvial Plain just west of the well field indicated that the confining unit separating the alluvial aquifer from the Memphis aquifer locally is absent. Differences in hydraulic head between the alluvial and fluvial deposits aquifers and the Memphis aquifer favor downward leakage of ground water. Thus, the absence of the confining unit beneath the Mississippi Alluvial Plain just west of the well field provides a direct pathway for water in the alluvial aquifer to enter the Memphis aquifer.

Comparison of selected water-quality properties and major inorganic and trace element constituent concentrations in samples from the alluvial, fluvial deposits, and Memphis aquifers indicates that the source of ground water causing waterquality changes at the Davis well field is the alluvial aquifer west of the well field. The presence of tritium and chlorofluorocarbons in water from wells screened in the Memphis aquifer in the western part of the well field indicates that relatively young (post-1940) water from the alluvial aquifer has entered the Memphis aquifer.

NETPATH geochemical model code was used to mix waters from the alluvial aquifer with water from the Memphis aquifer using chloride as a conservative tracer. The resulting models indicated that a mixture containing 3 percent alluvial aquifer water mixed with 97 percent unaffected Memphis aquifer water would produce the chloride concentration measured in water from the Memphis aquifer well most affected by water-quality changes.

NETPATH also was used to calculate mixing percentages of alluvial and Memphis aquifer 
waters based on changes in the concentrations of selected dissolved major inorganic and trace element constituents that define the dominant reactions that occur during mixing. These models indicated that a mixture containing 18 percent alluvial aquifer water and 82 percent unaffected Memphis aquifer water would produce the major constituent and trace element concentrations measured in water from the Memphis aquifer well most affected by water-quality changes. However, these model simulations predicted higher dissolved methane concentrations than were measured in water samples from the Memphis aquifer wells.

\section{INTRODUCTION}

The quality of ground water pumped at the Memphis Light, Gas and Water Division (MLGW) Davis well field at Memphis, Tennessee, has changed since the well field first began production in 1971. Analyses of water samples collected from wells in the well field in 1972, 1973, and 1982 by MLGW indicated an increase in values for hardness and alkalinity and in concentrations of chloride, sulfate, and iron in samples from well M419 during this 11-year period. Hardness increased 159 percent; alkalinity, 129 percent; chloride, 33 percent; sulfate, 300 percent; and iron, 255 percent. Initially, water-quality changes in samples from this well seemed anomalous when compared to analytical results of samples from other wells in the well field. An early explanation postulated for the water-quality change in well M419 was leakage of ground water from the shallower fluvial deposits aquifer to the deeper (confined) Memphis aquifer down the annular space outside the well casing resulting from faulty well construction.

MLGW subsequently sampled most of the 14 production wells in the Davis well field in 1983, 1987, and 1988. These analyses indicated a similar trend of water-quality change between 1972 and 1988, not only in water from well M419, but also in water from wells M401, M414, M415, and M421. For example, analyses of water samples from these five wells indicated that hardness had increased 198 percent in samples from well M419, 74 percent in well M401, 82 percent in well M414, 91 percent in well M415, and 77 percent in well M421. Increases in hardness, as well as some other properties and constituent concentrations in sam- ples from the five wells, indicated that downward movement of ground water from the fluvial deposits aquifer to the deeper Memphis aquifer was not occurring as a result of faulty construction at a single well, but probably as leakage through the confining unit.

From 1988 to 1989 , a graduate student in the Department of Geological Sciences at Memphis State University [The University of Memphis (U of $M$ ) as of July 1, 1994] interpreted existing data as part of an investigation of water-quality changes in the Davis well field (Richardson, 1989). The U.S. Geological Survey (USGS) provided the student with information about the hydrogeology and copies of geophysical logs made in test holes drilled for the well field. MLGW provided the student with historical water-quality data from the 14 production wells.

Based on a series of contour maps showing the distributions of hardness in ground water at the well field in 1972 and 1988, total dissolved solids concentrations in 1987, and barium in 1988, and the presence of several tens of feet of clay in the confining unit overlying the Memphis aquifer in the well field, Richardson (1989) concluded that observed water-quality changes in the Memphis aquifer were the result of downward leakage from the alluvial aquifer beneath the Mississippi Alluvial Plain west of the well field. Richardson postulated that a "window" (an area where the confining unit separating the shallow aquifers from the Memphis aquifer is thin or absent) might exist in this area and that downward leakage might be occurring through this "window." Graham and Parks (1986) had interpreted an area of high potential for downward leakage from the alluvial aquifer to the Memphis aquifer in a north-south belt west of the Davis well field near the Mississippi River.

Water-quality changes in aquifers used for public water supply are of concern because these changes can indicate a potential for contamination to the aquifers by downward leakage from near-surface sources. In response to this concern, the USGS began a 2-year (1992 to 1994) investigation of the hydrogeology and water quality in the Davis well field area in cooperation with MLGW and $\mathrm{U}$ of $\mathrm{M}$. This investigation was conducted as two separate and independent efforts: (1) the USGS investigated the hydrogeology, ground-water quality, and source of the ground water causing waterquality changes in the Davis well field and (2) U of M modeled the ground-water-flow system in the Davis well field area using the USGS computer model MODFLOW (McDonald and Harbaugh, 1988) with the 
particle-tracking component MODPATH (Pollock, 1989).

\section{Purpose and Scope}

This report presents the results of a USGS investigation of the hydrogeology, water-quality, and source of ground water causing water-quality changes in the Davis well field. The report also presents construction diagrams and gamma-ray logs for 12 wells installed in the alluvium and fluvial deposits in the Davis well field area and lithologic data for the test holes drilled for these wells (Appendix 1).

Major tasks conducted during the USGS investigation included (1) studying the hydrogeology of the Davis well field area; (2) collecting water-quality data from wells screened in the alluvial, fluvial deposits, and Memphis aquifers; (3) collecting data on concentrations of tritium, stable isotopes of carbon, and chlorofluorocarbons in ground water; and (4) generating geochemical models of ground-water mixing using the model code NETPATH. These data were interpreted to determine the source of ground water causing waterquality changes in water from wells screened in the Memphis aquifer.

The study area consisted of about 10 square miles in southwestem Shelby County, including the Davis well field of Memphis Light, Gas and Water Division and adjacent areas (fig. 1). The investigation was limited to a study of the alluvial and fluvial deposits aquifers and the upper and middle parts of the Memphis aquifer.

\section{Acknowledgments}

The authors gratefully acknowledge the assistance provided by employees of the City of Memphis, well drillers, and others who provided data and access to wells. Mr. James H. Webb, MLGW, provided historical water-quality data for 14 production wells in the Davis well field. Mr. Fred P. Von Hofe, MLGW, provided driller's logs and well-construction diagrams for these production wells. Mr. William J. Cole, MLGW, arranged for air-line or taped water-level measurements in 13 production wells and scheduled pumping of production wells on lots with shallow wells equipped with water-level recorders. Mr. Rodney E. Eder and Mr. J. Paul Patterson, City of Memphis, Department of Public Works, provided access for water-level mea- surements in several shallow observation wells near the well field. Mr. John Gordon of Hall, Blake and Associates, Inc., provided borehole diagrams for geotechnical borings drilled in conjunction with installation of the 12 shallow wells for this project.

\section{WELL FIELD DESCRIPTION}

The Davis well field is located in an undeveloped area of Memphis in southwestern Shelby County, Tennessee (fig. 1). The well field consists of 14 production wells (fig. 2) that were installed in 1970 and 1971; pumping began in August 1971. Production wells are located on MLGW lots spaced about 1,000 feet apart to lessen areal water-level drawdown as a result of pumping. The wells range from 412 to 606 feet deep and are screened in the upper to middle parts of the Memphis aquifer--the principal aquifer that supplies water for domestic, agricultural, commercial, industrial, and municipal use in the Memphis area. Screens in all wells are 80 feet long. The tops of the screens range from 332 to 526 feet below land surface. Well yields range from about 1,000 to 1,500 gallons per minute.

Near the center of the Davis well field are a pumping station and water-supply treatment plant (fig. 2). The pumping station and treatment plant have a design capacity of about 15 million gallons per day. Pumpage at the well field from 1972 to 1992 has averaged about 12 million gallons per day.

Ground water pumped from the 14 wells is treated by aeration and filtration. The water is passed through coke trays to remove carbon dioxide and hydrogen sulfide. Iron and manganese are oxidized during the aeration process and are removed by passing the water through rapid-sand filters. Chlorine is added to inhibit bacterial contamination; and hydrofluorosilicic acid is added to reduce tooth decay in children (James $\mathrm{H}$. Webb, Memphis Light, Gas and Water Division, oral commun., 1993).

\section{PHYSIOGRAPHIC SETTING}

The Davis well field is located in the Gulf Coastal Plain physiographic province just east of the Mississippi Alluvial Plain (Fenneman, 1938). The boundary between the Gulf Coastal Plain and the Mississippi Alluvial Plain is at the base of the Mississippi River bluffs (fig. 1). Altitudes in the Gulf Coastal Plain in the Davis well field area range from about 310 feet above 


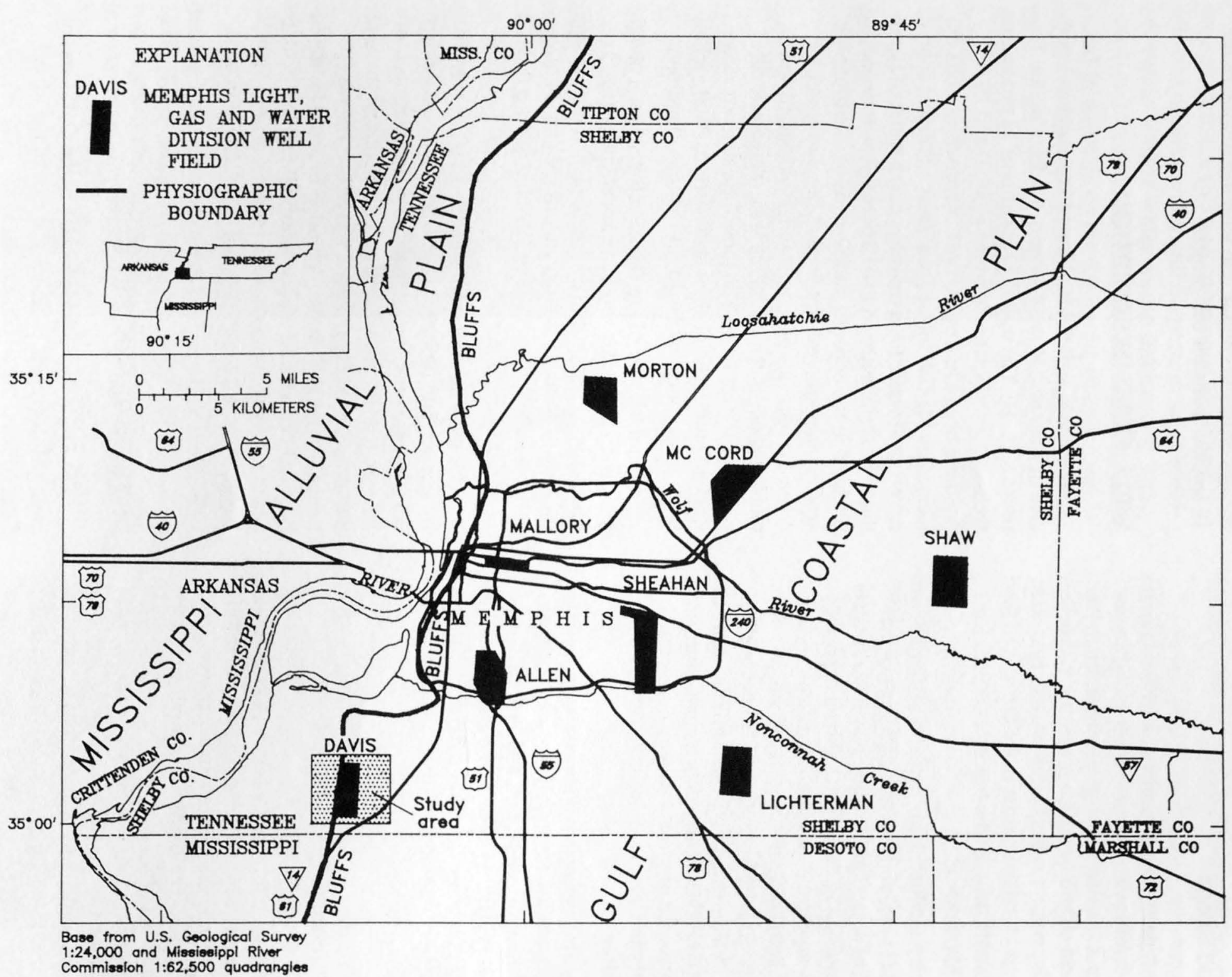

Figure 1. Major physiographic subdivisions in the Memphis area and location of principal Memphis Light, Gas and Water Division well fields and the study area. 


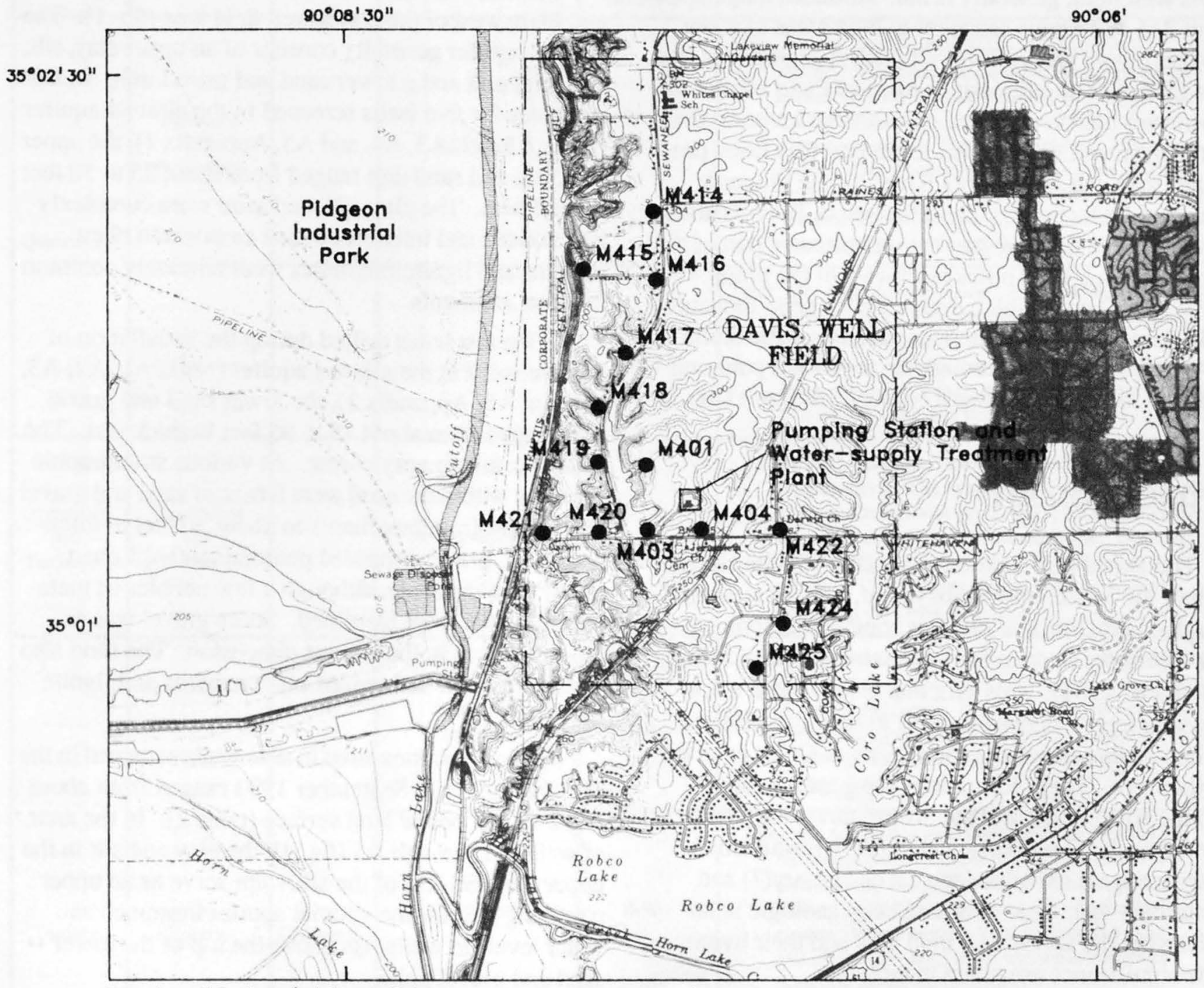

Base from U.S. Geological Survey Flotcher

Loke, 1968, and Southweet Memphis, 1965,

1:24,000 Photoreviaion of 1973

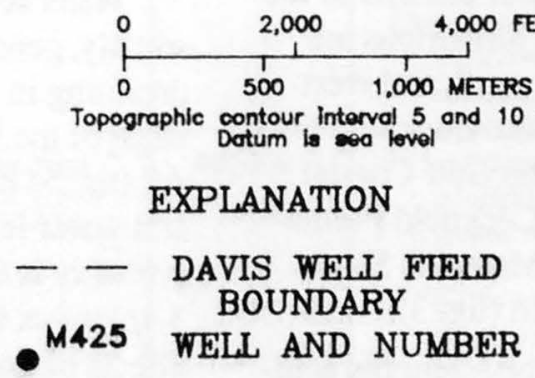

Figure 2. Location of the study area, the 14 production wells, pumping station, and water-supply treatment plant within the Davis well field, Memphis, Tennessee. 
sea level at the top of the bluffs to about 210 feet near their base; thus, the bluffs have a maximum relief of about 100 feet. The topography of the upland areas east of the bluffs is moderately steep to gently rolling, but the alluvial plains of streams that cross these areas are nearly flat.

The Mississippi Alluvial Plain, just west of the Davis well field, generally is flat. Altitudes range from about 215 feet above sea level in high areas to about 200 feet in low areas. Thus, total relief generally is less than 15 feet. The Mississippi Alluvial Plain west of the Davis well field is enclosed by a 30 -foot levee on the north, west, and south. This levee provides flood protection from the Mississippi River for the Pidgeon Industrial Park (fig. 2). The Mississippi River is about $1 / 2$ to $3 / 4$ mile northwest of the westernmost part of the levee, or about $31 / 2$ miles northwest of the bluffs. Hom Lake Cutoff, which drains the Pidgeon Industrial Park, flows north to south near the base of the bluffs and enters Horn Lake through the levee at a pumping station near the southeastern comer of the park (fig. 2).

\section{HYDROGEOLOGY}

The Davis well field area is located on the eastern limb of the Mississippi embayment, a broad structural trough or syncline that plunges southward along an axis that approximates the Mississippi River (Cushing and others, 1964). This syncline is filled with a few thousand feet of unconsolidated to semiconsolidated sediments that constitute formations of Cretaceous and Tertiary age. These formations dip gently westward into the embayment and southward down the axis. Overlying the Cretaceous and Tertiary formations in many areas are surficial deposits of Tertiary(?) and Quaternary age. Post-Wilcox Group geologic units underlying the Davis well field area and their hydrologic significance are given in table 1 .

Because the Davis well field is near the axis of the Mississippi embayment, the Tertiary formations are essentially flat, dipping gently to the south and west (fig. 3). The fluvial deposits overlie the Cockfield Formation beneath the upland areas of the Gulf Coastal Plain, and the alluvium overlies the Cockfield Formation, Cook Mountain Formation, or Memphis Sand beneath the Mississippi Alluvial Plain (fig. 3).

The Memphis Sand constitutes the Memphis aquifer, the fluvial deposits constitute the fluvial deposits aquifer, and the alluvium constitutes the alluvial aqui- fer. The Cook Mountain and Cockfield Formations serve as a confining unit separating the fluvial deposits and alluvial aquifers from the deeper Memphis aquifer.

\section{Alluvial Aquifer}

The alluvial aquifer underlies the Mississippi Alluvial Plain west of the Davis well field area (fig. 1). The alluvial aquifer generally consists of an upper clay, silt, and sand unit and a lower sand and gravel unit. In the test holes for five wells screened in the alluvial aquifer (wells A1, A2, A3, A4, and A5, Appendix 1), the upper clay, silt, and sand unit ranged from about 35 to 50 feet in thickness. The clay, silt, and sand were complexly interbedded and interlensed, and carbonized plant remains and lignite fragments were relatively common in these sediments.

In the test holes drilled during the installation of the five wells in the alluvial aquifer (wells A1, A2, A3, A4, and A5, Appendix 1), the lower sand and gravel unit ranged from about 15 to 95 feet in thickness. The sand was fine to very coarse. At various stratigraphic horizons within the sand were lenses of sand and gravel that ranged from less than 1 to about 30 feet in thickness. The gravel consisted predominantly of chert, quartz, and quartzite, although a few pebbles of metamorphic rock were identified. Some gravel was as large as 1 inch in the longest dimension. The sand also contained some carbonized plant remains and lignite fragments.

Water levels measured in nine wells screened in the alluvial aquifer in September 1993 ranged from about 14 to 19 feet below land surface (table 2). In the area of wells A1 through A5 (fig. 4), the clay and silt in the upper 20 to 50 feet of the alluvium serve as an upper confining unit for the alluvial aquifer inasmuch as water levels in wells rise above the top of the lower sand and gravel unit.

Water levels in the alluvial aquifer fluctuate seasonally, generally rising in the winter and spring and declining in the summer and fail (fig. 5). A plot of the stage of the Mississippi River and water levels in well A2 (fig. 5) indicates no correlation between river stage and water-level fluctuations. This lack of correlation probably is the result of well A2 being about 3 1/2 miles from the Mississippi River, or the local effects of downward leakage from the alluvial aquifer to the Memphis aquifer as a result of pumping at the Davis well field. 
Table 1. Post-Wilcox Group geologic units underlying the Davis well field area, Memphis, Tennessee, and their hydrologic significance

[Compiled from Parks (1973), Parks (1978), Kingsbury and Parks (1993)]

\begin{tabular}{|c|c|c|c|c|c|}
\hline System & Series & Group & Stratigraphic unit & $\begin{array}{l}\text { Thickness } \\
\text { (in feet) }\end{array}$ & Lithology and hydrologic significance \\
\hline \multirow[t]{2}{*}{ Quaternary } & $\begin{array}{l}\text { Holocene } \\
\text { and } \\
\text { Pleistocene }\end{array}$ & & Alluvium & $0-150$ & $\begin{array}{l}\text { Quartz sand, gravel, silt, and clay. Underlies the } \\
\text { Mississippi Alluvial Plain and the alluvial plains of } \\
\text { streams draining the Gulf Coastal Plain. Upper part } \\
\text { consists of fine sand, silt and clay; lower part consists } \\
\text { of sand and gravel. Thickest beneath the Mississippi } \\
\text { Alluvial Plain where it is as much as about } 150 \text { feet } \\
\text { thick; generally less than about } 50 \text { feet thick elsewhere. } \\
\text { Beneath the Mississippi Alluvial Plain, alluvium } \\
\text { constitutes the Mississippi River Valley alluvial aquifer. }\end{array}$ \\
\hline & Pleistocene & & Loess & $0-60$ & $\begin{array}{l}\text { Silt, silty clay, and minor sand. Principal unit at the surface } \\
\text { in upland areas of the Gulf Coastal Plain, concealing } \\
\text { older Quaternary and Tertiary formations at most places. } \\
\text { Thickest on the bluffs that border the Mississippi Alluvial } \\
\text { Plain. Generally retards downward movement of water } \\
\text { that provides recharge to the fluvial deposits aquifer. }\end{array}$ \\
\hline $\begin{array}{l}\text { Quatemary } \\
\quad \text { and } \\
\text { Tertiary(?) }\end{array}$ & $\begin{array}{l}\text { Pleistocene } \\
\text { and } \\
\text { Pliocene (?) }\end{array}$ & & Fluvial deposits & $0-65$ & $\begin{array}{l}\text { Quartz sand, gravel, and minor clay and sandstone. } \\
\text { Underlie the loess in upland areas. Generally consist } \\
\text { of sand with lenses of gravel and some clay. Locally } \\
\text { cemented to form ferruginous sandstone. Thickness } \\
\text { varies greatly because of erosional surfaces at top } \\
\text { and base. Constitute the fluvial deposits aquifer in } \\
\text { the area of the Davis well field. }\end{array}$ \\
\hline \multirow{3}{*}{ Tertiary } & \multirow{3}{*}{ Eocene } & \multirow{3}{*}{ Claibome } & $\begin{array}{l}\text { Cockfield } \\
\text { Formation }\end{array}$ & $0-100$ & $\begin{array}{l}\text { Quartz sand, silt, clay, and lignite. Complexly interbedded } \\
\text { and interlensed; lithologies vary greatly over short } \\
\text { distances and depths. Only lower part of formation } \\
\text { preserved; upper surface is severely eroded. Serves as } \\
\text { part of the upper confining unit overlying the } \\
\text { Memphis aquifer. }\end{array}$ \\
\hline & & & $\begin{array}{l}\text { Cook Mountain } \\
\text { Formation }\end{array}$ & $0-90$ & $\begin{array}{l}\text { Clay, silt, and sand. Generally consists of clay and silt, } \\
\text { but locally contains lenses of very fine sand in lower } \\
\text { part. Locally absent beneath the Mississippi Alluvial } \\
\text { Plain where the formation has been removed by } \\
\text { erosion. Where present, is the thickest and most } \\
\text { widespread clay layer in the upper confining unit } \\
\text { overlying the Memphis aquifer. }\end{array}$ \\
\hline & & & Memphis Sand & $880-900$ & $\begin{array}{l}\text { Quartz sand, silt, clay, and minor lignite. Consists of a } \\
\text { thick body of sand with clay or silt lenses at various } \\
\text { stratigraphic horizons. Sand is fine to very coarse. } \\
\text { Upper part contains lenses of very fine sand, silt, } \\
\text { and clay. Constitutes the Memphis aquifer--the } \\
\text { principal aquifer in the Memphis area. Supplies most } \\
\text { ground water pumped at Memphis Light, Gas and } \\
\text { Water Division well fields, including that pumped from } \\
\text { the } 14 \text { wells at the Davis well field. Underlain by the } \\
\text { Flour Island Formation of the Wilcox Group, which } \\
\text { serves as a lower confining unit. }\end{array}$ \\
\hline
\end{tabular}



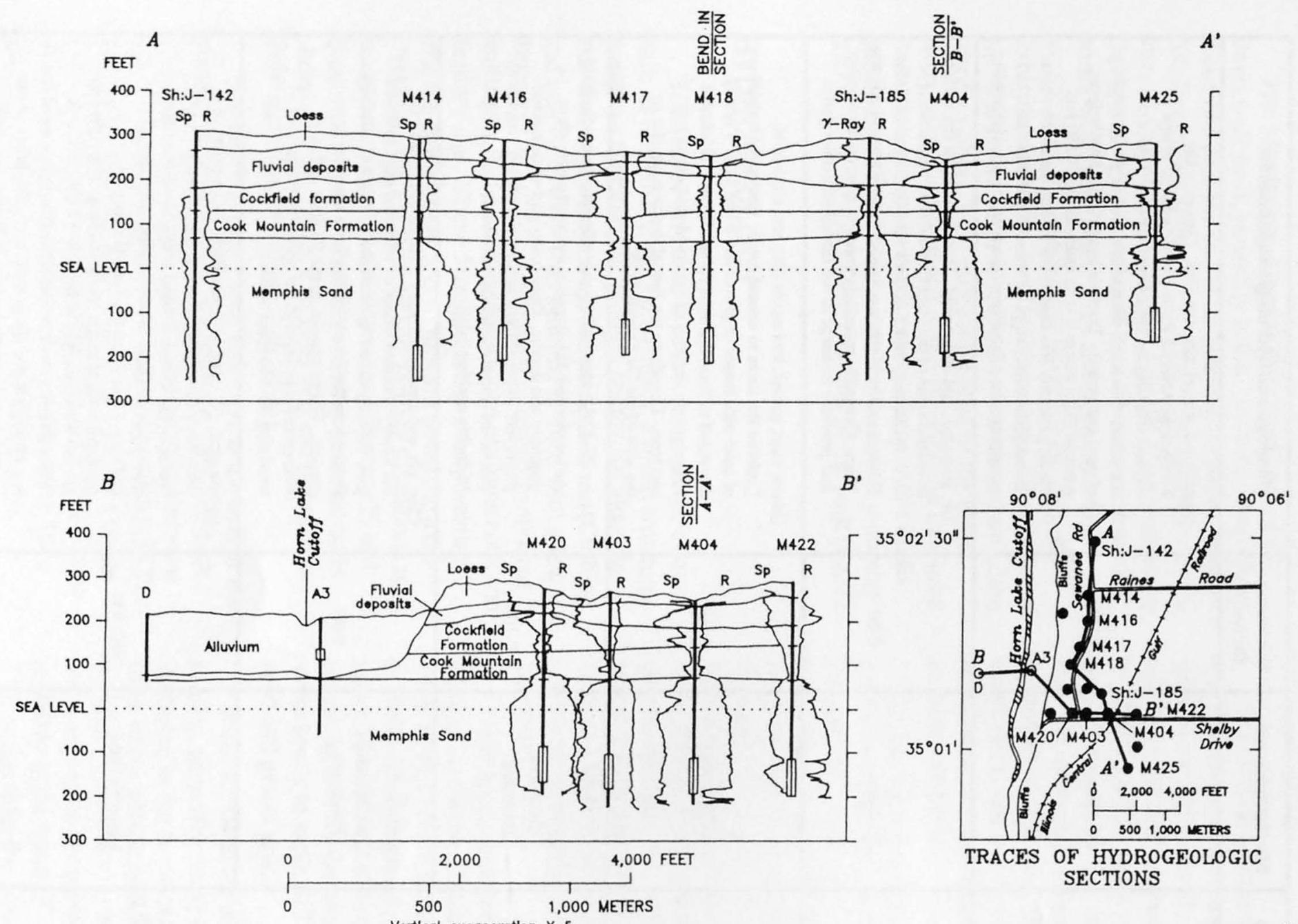

GEOPHYSICAL LOGS

CONTACT--Based on lithologic Sh:J-185 USGS LOCAL WELL NUMBER information and geophysicallog correlation
FOR TENNESSEE
D TEST HOLE WITH LITHOLOGIC LOG

M425 PROJECT AND MAP NUMBER FOR THIS REPORT
(1) SCREENED INTERVAL OF WELL

Figure 3. Hydrogeologic sections A-A' and B-B' through the Davis well field area, Memphis, Tennessee.

Sp SPONTANEOUS POTENTIAL ON ELECTRIC LOG

$R$ RESISTANCE ON ELECTRIC LOG

r-Ray GAMNA-RAY LOG--Radioactivity increases $\rightarrow$ 
Table 2. Water levels measured in 33 wells screened in the alluvial, fluvial deposits, and Memphis aquifers in the Davis well field area, Memphis, Tennessee

[ ${ }^{\circ}$, degrees, ', minutes, ", seconds; water levels in hundredths of a foot are taped measurements; those in feet are air-line measurements]

\begin{tabular}{|c|c|c|c|c|c|c|c|c|}
\hline \multicolumn{2}{|c|}{ Well numbers } & & & \multirow{2}{*}{$\begin{array}{l}\text { Altitude of } \\
\text { land surface, } \\
\text { In feet } \\
\text { above sea } \\
\text { level }\end{array}$} & \multirow{2}{*}{$\begin{array}{l}\text { Screened } \\
\text { Interval, } \\
\text { in feet } \\
\text { below land } \\
\text { surface }\end{array}$} & \multicolumn{2}{|c|}{$\begin{array}{c}\text { Water-level } \\
\text { below land surface } \\
\end{array}$} & \multirow{2}{*}{$\begin{array}{c}\text { Altitude of } \\
\text { water level, } \\
\text { in feet } \\
\text { above sea } \\
\text { level }\end{array}$} \\
\hline $\begin{array}{l}\text { and } \\
\text { map }\end{array}$ & $\begin{array}{c}\text { for } \\
\text { Tennessee }\end{array}$ & Latitude & Longitude & & & $\begin{array}{l}\text { Depth, } \\
\text { in feet }\end{array}$ & $\begin{array}{c}\text { Date of } \\
\text { measurement }\end{array}$ & \\
\hline
\end{tabular}

$\begin{array}{llllllll}\text { A1 } & \text { Sh:H-17 } & 35^{\circ} 00^{\prime} 54^{\prime \prime} & 9^{\circ} 08^{\prime} 04^{\prime \prime} & 211 & 38-48 & 18.05 & 9-15-93 \\ \text { A2 } & \text { Sh:H-18 } & 35^{\circ} 01^{\prime} 14^{\prime \prime} & 90^{\circ} 08^{\prime} 00^{\prime \prime} & 209 & 64-84 & 17.42 & 9-15-93 \\ \text { A3 } & \text { Sh:H-19 } & 35^{\circ} 01^{\prime} 34^{\prime \prime} & 90^{\circ} 08^{\prime} 00^{\prime \prime} & 210 & 70-90 & 19.32 & 193 \\ \text { A4 } & \text { Sh:H-20 } & 35^{\circ} 01^{\prime} 54^{\prime \prime} & 90^{\circ} 07^{\prime} 58^{\prime \prime} & 211 & 75-95 & 18.95 & 9-15-93 \\ \text { A5 } & \text { Sh:H-21 } & 35^{\circ} 02^{\prime} 13^{\prime \prime} & 90^{\circ} 07^{\prime} 57^{\prime \prime} & 206 & 56-76 & 13.57 & 19-93 \\ \text { None } & \text { Sh:H-25 } & 35^{\circ} 01^{\prime} 13^{\prime \prime} & 90^{\circ} 08^{\prime} 41^{\prime \prime} & 214 & 25-35 & 15.72 & 9-15-93 \\ \text { None } & \text { Sh:H-26 } & 35^{\circ} 01^{\prime} 50^{\prime \prime} & 9^{\circ} 08^{\prime} 54^{\prime \prime} & 209 & 28-38 & 15.85 & 9-17-93 \\ \text { None } & \text { Sh:H-27 } & 35^{\circ} 02^{\prime} 01^{\prime \prime} & 90^{\circ} 90^{\prime} 04^{\prime \prime} & 211 & 26-36 & 16.18 & 9-17-93 \\ \text { None } & \text { Sh:H-28 } & 35^{\circ} 02^{\prime} 07^{\prime \prime} & 9^{\circ} 09^{\prime} 08^{\prime \prime} & 212 & 27-37 & 19.20 & 9-17-93 \\ \end{array}$

\begin{tabular}{|c|c|c|c|c|c|c|c|c|}
\hline F401 & Sh:J-189 & $35^{\circ} 01^{\prime} 25^{\prime \prime}$ & $90^{\circ} 07^{\prime} 29^{\prime \prime}$ & 290 & $72-82$ & 46.93 & $9-15-93$ & 243 \\
\hline F403 & Sh:J-188 & $35^{\circ} 05^{\prime} 15^{\prime \prime}$ & $90^{\circ} 07^{\prime} 29^{\prime \prime}$ & 257 & $58-68$ & 17.16 & $9-15-93$ & 240 \\
\hline F414 & Sh:J-191 & $35^{\circ} 02^{\prime} 07^{\prime \prime}$ & $90^{\circ} 07^{\prime} 27^{\prime \prime}$ & 295 & $74-84$ & 72.40 & $9-15-93$ & 223 \\
\hline F415 & Sh:H-23 & $35^{\circ} 01^{\prime} 57^{\prime \prime}$ & $90^{\circ} 07^{\prime} 42^{\prime \prime}$ & 305 & $79-89$ & 78.44 & $9-15-93$ & 227 \\
\hline F416 & Sh:J-190 & $35^{\circ} 01^{\prime} 56^{\prime \prime}$ & $90^{\circ} 07^{\prime 2} 26^{\prime \prime}$ & 295 & $75-85$ & 65.12 & $9-15-93$ & 230 \\
\hline F419 & Sh:H-22 & $35^{\circ} 01^{\prime} 26^{\prime \prime}$ & $90^{\circ} 07^{\prime} 39^{\prime \prime}$ & 251 & $45-55$ & 14.37 & $9-15-93$ & 237 \\
\hline F421 & Sh:H-24 & $35^{\circ} 01^{\prime} 15^{\prime \prime}$ & $90^{\circ} 07^{\prime} 50^{\prime \prime}$ & 254 & $35-45$ & 24.25 & $9-15-93$ & 230 \\
\hline F422 & Sh:J-193 & $35^{\circ} 01^{\prime} 14^{\prime \prime}$ & $90^{\circ} 07^{\prime} 03 "$ & 283 & $81-91$ & 39.32 & $9-15-93$ & 244 \\
\hline \multirow[t]{2}{*}{ None } & Sh:J-172 & $35^{\circ} 01^{\prime} 24^{\prime \prime}$ & $90^{\circ} 07^{\prime} 22^{\prime \prime}$ & 292 & $100-110$ & 48.82 & $9-15-93$ & 243 \\
\hline & \multicolumn{8}{|c|}{ Memphis aquifer } \\
\hline M401 & Sh:J-143 & $35^{\circ} 01^{\prime} 25^{\prime \prime}$ & $90^{\circ} 07^{\prime 2} 29^{\prime \prime}$ & 291 & $370-450$ & 115 & $9-14-93$ & 176 \\
\hline M403 & Sh:H-10 & $35^{\circ} 01^{\prime} 15^{\prime \prime}$ & $90^{\circ} 07^{\prime 2} 29^{\prime \prime}$ & 258 & $368-448$ & 84 & $9-15-93$ & 174 \\
\hline M414 & Sh:J-145 & $35^{\circ} 02^{\prime} 07^{\prime \prime}$ & $90^{\circ} 07^{\prime} 27^{\prime \prime}$ & 295 & $388-468$ & 114 & $9-17-93$ & 181 \\
\hline M415 & Sh:H-8 & $35^{\circ} 01^{\prime} 57^{\prime \prime}$ & $90^{\circ} 07^{\prime} 42^{\prime \prime}$ & 304 & $526-606$ & 126 & $9-15-93$ & 178 \\
\hline M416 & Sh:J-137 & $35^{\circ} 01^{\prime} 56^{\prime \prime}$ & $90^{\circ} 07^{\prime 26} "$ & 295 & $415-495$ & 117 & $9-17-93$ & 178 \\
\hline M417 & Sh:H-7 & $35^{\circ} 01^{\prime} 44^{\prime \prime}$ & $90^{\circ} 07^{\prime 3} 33^{\prime \prime}$ & 264 & $380-460$ & 90 & $9-14-93$ & 174 \\
\hline M418 & Sh:H-6 & $35^{\circ} 01 ' 35^{\prime \prime}$ & $90^{\circ} 07 ' 39^{\prime \prime}$ & 257 & $375-455$ & 89 & $9-15-93$ & 168 \\
\hline M419 & Sh:H-5 & $35^{\circ} 01^{\prime} 26^{\prime \prime}$ & $90^{\circ} 07^{\prime 3} 39^{\prime \prime}$ & 251 & $332-412$ & 75 & $9-14-93$ & 176 \\
\hline M420 & Sh:H-11 & $35^{\circ} 01^{\prime} 15^{\prime \prime}$ & $90^{\circ} 07^{\prime 3} 39^{\prime \prime}$ & 273 & $366-440$ & 88 & $9-14-93$ & 185 \\
\hline M421 & Sh:H-9 & $35^{\circ} 01^{\prime} 15^{\prime \prime}$ & $90^{\circ} 07 ' 50^{\prime \prime}$ & 243 & $360-440$ & 66 & $9-17-93$ & 177 \\
\hline M422 & Sh:J-141 & $35^{\circ} 01^{\prime} 14^{\prime \prime}$ & $90^{\circ} 07^{\prime} 03^{\prime \prime}$ & 286 & $400-480$ & 110 & $9-14-93$ & 176 \\
\hline M424 & Sh:J-139 & $35^{\circ} 01^{\prime} 00^{\prime \prime}$ & $90^{\circ} 07^{\prime} 03^{\prime \prime}$ & 290 & $380-460$ & 119 & $9-15-93$ & 171 \\
\hline M425 & Sh:J-144 & $35^{\circ} 00^{\prime} 52^{\prime \prime}$ & $90^{\circ} 07^{\prime} 08^{\prime \prime}$ & 284 & $370-450$ & 102 & $9-15-93$ & 182 \\
\hline None & Sh:J-1 & $35^{\circ} 00^{\prime} 02^{\prime \prime}$ & $90^{\circ} 05^{\prime} 44^{\prime \prime}$ & 240 & $327-334$ & 56.55 & $9-15-93$ & 183 \\
\hline None & Sh:J-140 & $35^{\circ} 01^{\prime 2} 24^{\prime \prime}$ & $90^{\circ} 07^{\prime 22}$ & 293 & $543-553$ & 116.98 & 9-15-93 & 176 \\
\hline
\end{tabular}




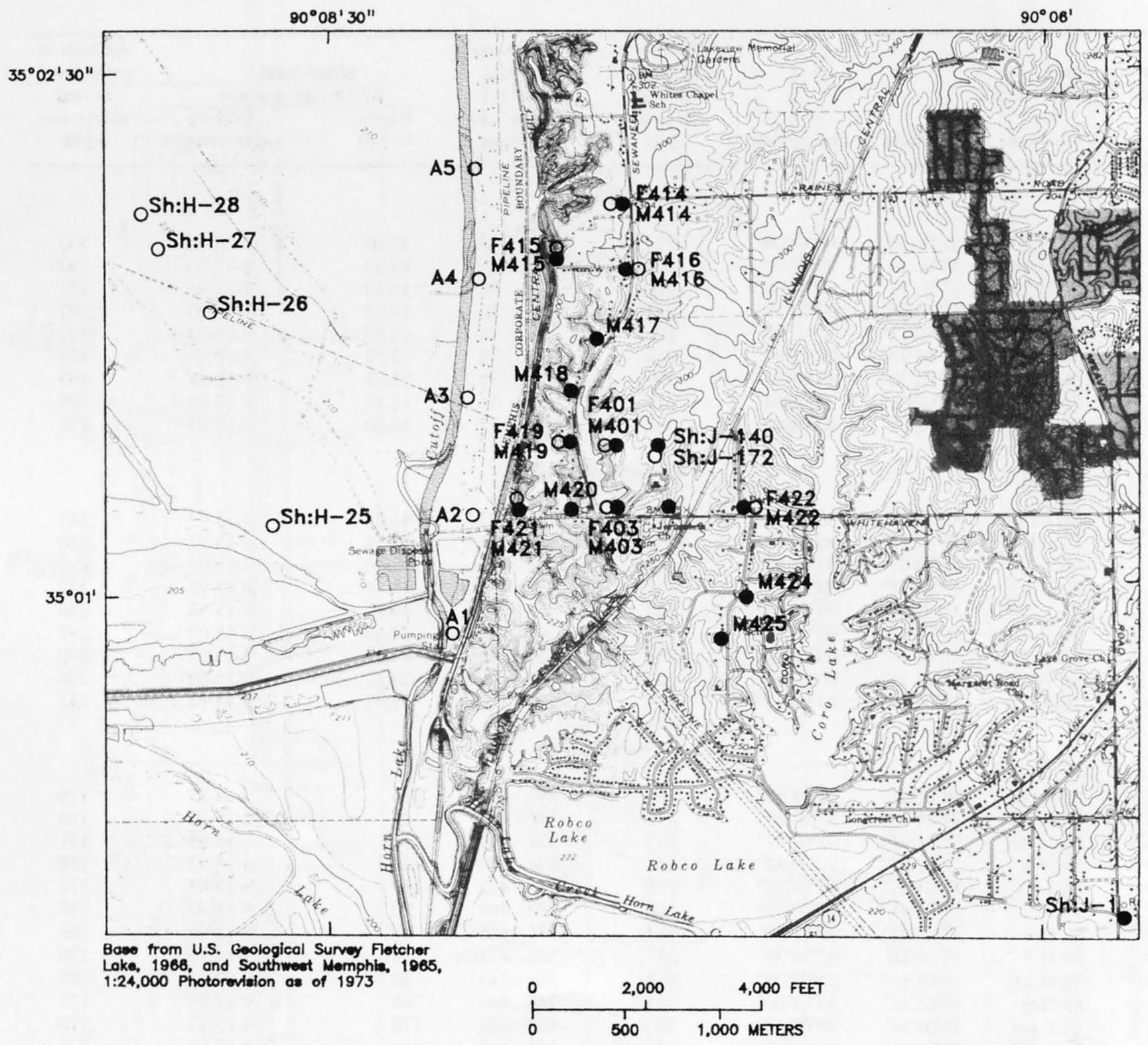

EXPLANATION
OA1 WELL SCREENED IN THE ALLUVIAL OR FLUVIAL DEPOSITS AQUIFER AND WELL NUMBER -M425 WELL SCREENED IN THE MEMPHIS
AQUIFER AND WELL NUMBER

Figure 4. Location of wells in which water levels were measured in the Davis well field area, Memphis, Tennessee, September 1993. 

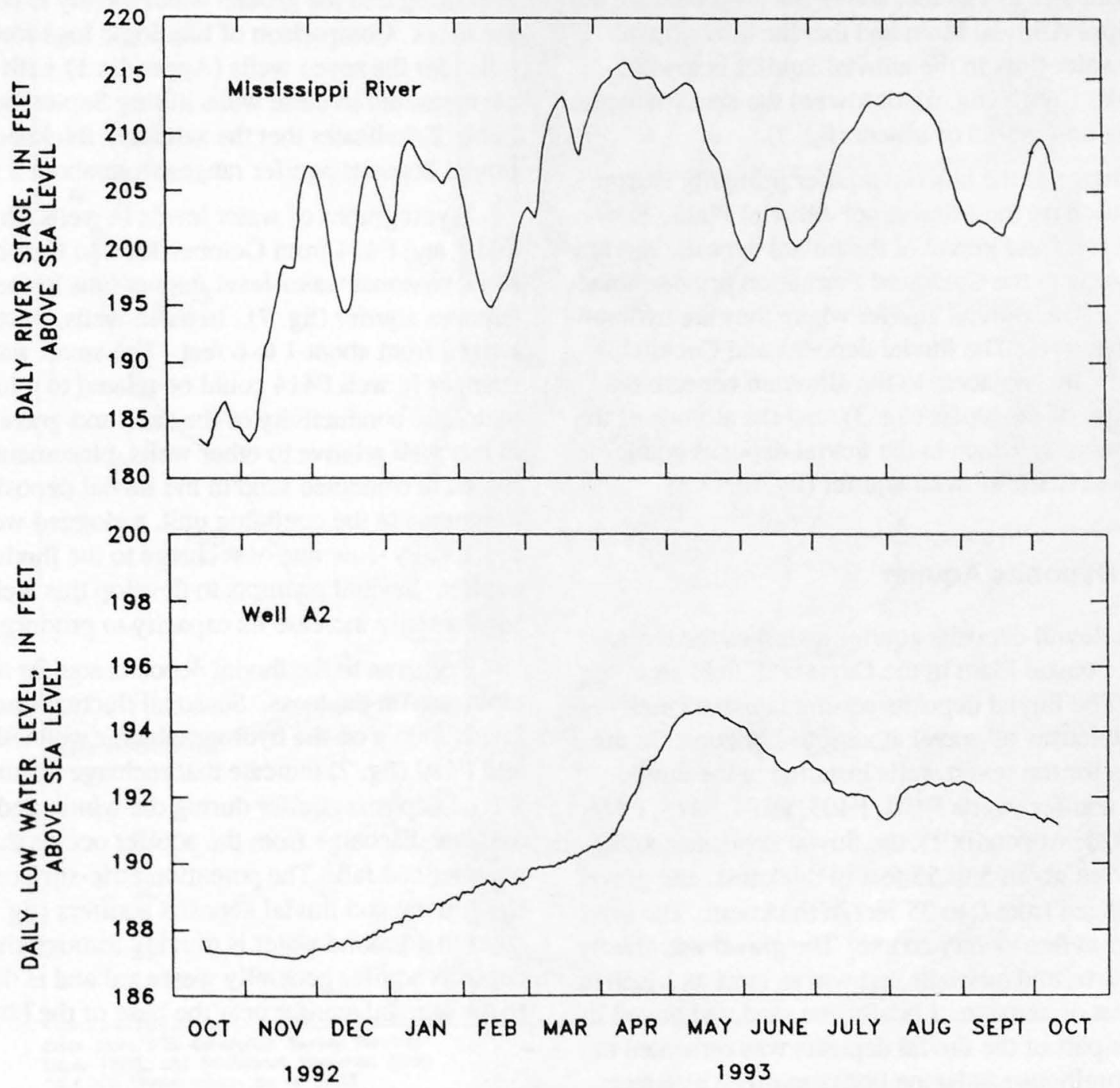

Figure 5. Water levels recorded in well A2 screened in the alluvial aquifer and stage of the Mississippi River at Memphis, Tennessee, October 1992 to October 1993. 
Water levels measured in nine wells screened in the alluvial aquifer and in nine wells screened in the fluvial deposits aquifer (table 2 ) were used to prepare a potentiometric-surface map in the area of the Davis well field (fig. 6). This map shows that the altitude of the potentiometric surface in the alluvial aquifer ranges from about 191 to 198 feet above sea level beneath the Mississippi Alluvial Plain and that the direction of ground-water flow in the alluvial aquifer is toward Horn Lake Cutoff (fig. 6), or toward the area where the confining unit is thin or absent (fig. 3).

Recharge to the alluvial aquifer primarily is from precipitation on the Mississippi Alluvial Plain. However, the sand and gravel of the fluvial deposits and lenticular sands in the Cockfield Formation provide some recharge to the alluvial aquifer where they are hydraulically connected. The fluvial deposits and Cockfield Formation are subjacent to the alluvium beneath the buried base of the bluffs (fig. 3), and the altitude of the potentiometric surface in the fluvial deposits aquifer is higher than in the alluvial aquifer (fig. 6).

\section{Fluvial Deposits Aquifer}

The fluvial deposits aquifer underlies the loess in the Gulf Coastal Plain in the Davis well field area (fig. 1). The fluvial deposits aquifer consists chiefly of sand with lenses of gravel at various horizons. In the test holes for the seven wells installed in the fluvial deposits aquifer (wells F401, F403, F414, F415, F416, F419, F421, Appendix 1), the fluvial deposits aquifer ranged from about 5 to 55 feet in thickness, and gravel lenses ranged from 0 to 35 feet in thickness. The sand ranged from fine to very coarse. The gravel was chiefly chert, quartz, and quartzite and was as large as 1 inch in the longest dimension. Locally, the sand and gravel in the lower part of the fluvial deposits was cemented to form ferruginous sandstone layers as much as 4 feet thick.

The fluvial deposits are overlain by loess, which ranged from about 25 to 60 feet in thickness in the test holes for the seven wells installed in the fluvial deposits aquifer for this investigation (wells F401, F403, F414, F415, F416, F419, F421, Appendix 1). The loess consisted of silt with some interbeds of clayey silt or silty clay. The loess tends to retard downward movement of recharge to the fluvial deposits aquifer and locally serves as an upper confining unit.

Water levels in nine wells screened in the fluvial deposits aquifer ranged from 14 to 78 feet below land surface in September 1993 (table 2). In most wells in the higher altitude areas, water levels were as much as 20 feet below the top of the fluvial deposits, indicating that the aquifer generally is unconfined. However, in a few wells in the lower altitude areas, water levels were as much as 12 feet above the top of the fluvial deposits, indicating that the ground water locally is confined by the loess. Comparison of lithologic logs for the test holes for the seven wells (Appendix 1) with water levels measured in these wells during September 1993 (table 2) indicates that the saturated thickness of the fluvial deposits aquifer ranges from about 5 to 55 feet.

Hydrographs of water levels in wells Sh:J-172, F419, and F414 from October 1992 to October 1993 show seasonal water-level fluctuations in the fluvial deposits aquifer (fig. 7). In these wells, fluctuations ranged from about 1 to 6 feet. The small water-level changes in well F414 could be related to a lower hydraulic conductivity of the sand and gravel screened in this well relative to other wells, placement of the screen in cemented sand in the fluvial deposits or fine sediments in the confining unit, a clogged well screen, or a locally slow rate of recharge to the fluvial deposits aquifer. Several attempts to develop this well did not substantially increase its capacity to produce water.

Recharge to the fluvial deposits aquifer is from precipitation on the loess. Seasonal fluctuations of water levels shown on the hydrographs for wells Sh:J-172 and F419 (fig. 7) indicate that recharge occurs in the fluvial deposits aquifer during the winter and spring and that discharge from the aquifer occurs during the summer and fall. The potentiometric-surface map of the alluvial and fluvial deposits aquifers (fig. 6) indicates that ground water is moving through the fluvial deposits aquifer generally westward and is discharged to the alluvial aquifer near the base of the bluffs.

\section{Confining Unit}

In the Davis well field area, the confining unit that separates the alluvial and fluvial deposits aquifers from the Memphis aquifer is part of the areally extensive Jackson Formation-upper Claiborne Group confining unit as recognized in the Memphis area (Parks, 1990). The Jackson Formation is present only in northwestern Shelby County (Parks and Carmichael, 1990a; Kingsbury and Parks, 1993), so the confining unit in the Davis well field area is made up only of the Cockfield and Cook Mountain Formations of the Claiborne Group (table 1). 


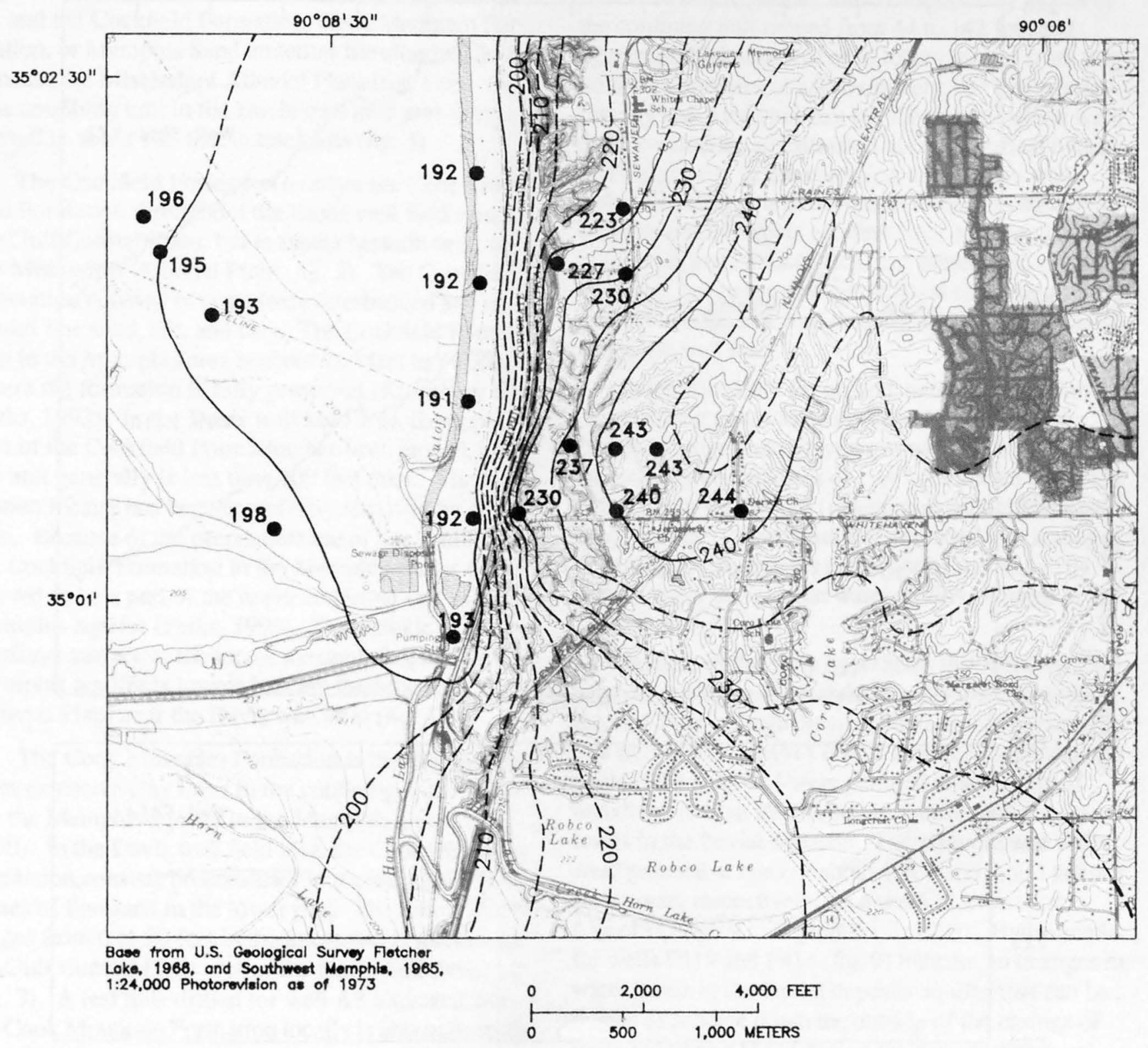

\section{EXPLANATION}

-210-- - WATER-TABLE CONTOUR--Shows altitude at which water would have stood in tightly cased wells. Dashed where approximately located. Contour interval 5 feet. Datum is sea level

193 WELL IN WHICH WATER LEVEL WAS MEASURED-Number is measured water-level altitude

Figure 6. Altitude of potentiometric surface in the alluvial and fluvial deposits aquifers in the Davis well field area, Memphis, Tennessee, September 1993. 


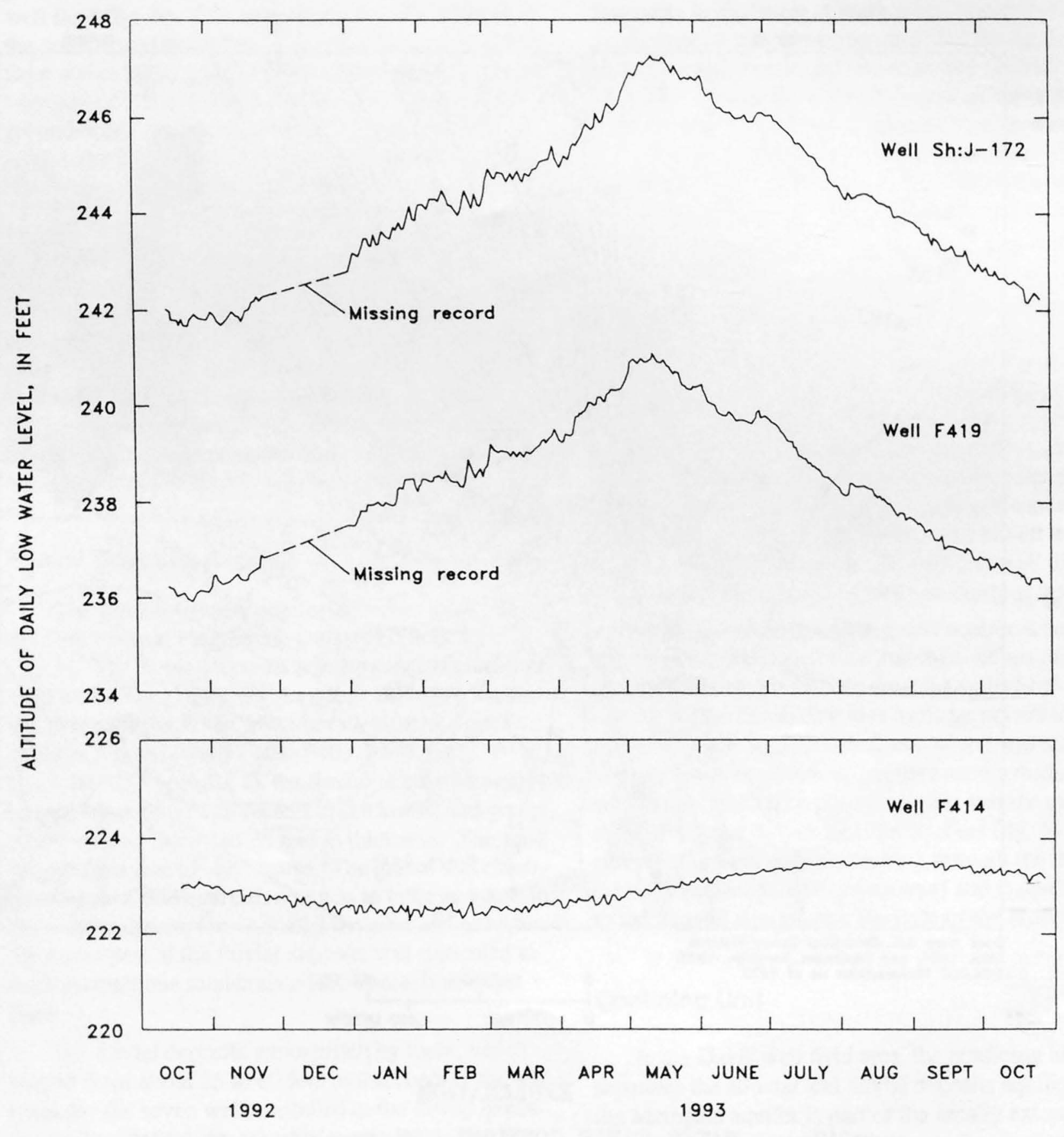

Figure 7. Water levels recorded in wells Sh:J-172, F419, and F414 screened in the fluvial deposits aquifer, Memphis, Tennessee, October 1992 to October 1993. 
The thickness of the confining unit is highly variable because of an erosional surface at its top (fig. 8). As a result of this erosional surface in the Davis well field area, the Cockfield Formation underlies the fluvial deposits aquifer in the Gulf Coastal Plain (figs. 1 and 3 ), and the Cockfield Formation, Cook Mountain Formation, or Memphis Sand underlies the alluvial aquifer beneath the Mississippi Alluvial Plain (fig. 1 and 3). The confining unit in the Davis well field area ranges from 0 to about 185 feet in thickness (fig. 3).

The Cockfield Formation overlies the Cook Mountain Formation throughout the Davis well field area of the Gulf Coastal Plain, but is absent beneath most of the Mississippi Alluvial Plain (fig. 3). The Cockfield Formation consists of complexly interbedded and interlensed fine sand, silt, and clay. The Cockfield Formation in the Memphis area is about 250 feet in thickness where the formation is fully preserved (Kingsbury and Parks, 1993). In the Davis well field area, the upper part of the Cockfield Formation has been eroded, and the unit generally is less than 100 feet thick. The formation locally has been completely removed by erosion. Because of the preponderance of fine sediments, the Cockfield Formation in the Memphis area is considered to be a part of the upper confining unit to the Memphis aquifer (Parks, 1990). The altitude of the erosional surface at the top of the confining unit or Memphis aquifer is lowest beneath the Mississippi Alluvial Plain near the Davis well field (fig. 8).

The Cook Mountain Formation is the thickest and most extensive clay layer in the confining unit overlying the Memphis aquifer in the Memphis area (Parks, 1990). In the Davis well field area, the Cook Mountain Formation consists predominantly of clay with minor lenses of fine sand in the lower part. The formation ranges from 0 to 90 feet in thickness and is thickest in the Gulf Coastal Plain area of the Davis well field (fig. 3). A test hole drilled for well A3 indicated that the Cook Mountain Formation locally is absent beneath the Mississippi Alluvial Plain (John Gordon, Hall, Blake and Associates, Inc., written commun., 1992) and that the alluvial aquifer directly overlies the Memphis aquifer in that area (fig. 3).

Clays and silts in the confining unit have low hydraulic conductivities. Because differences in hydraulic head between the alluvial and fluvial deposits aquifers and the Memphis aquifer in the Davis well field area favor downward leakage, small quantities of ground water undoubtedly move downward through the confining unit, but at slow rates.
For an evaluation of the potential for leakage of ground water from the fluvial deposits aquifer to the Memphis aquifer, Richardson (1989) determined from geophysical logs of 14 test holes drilled in the Davis well field that aggregate thicknesses of clay lenses in the confining unit ranged from 44 to 142 feet and aggregate thicknesses of sand lenses ranged from 0 to 96 feet. Estimates of approximately $10^{-3}$ feet per day for clay and 1 foot per day for silt and fine sands were used to calculate an estimated average vertical hydraulic conductivity of the confining unit at each well. Using these data, head differences between the fluvial deposits and Memphis aquifers from a map published in Graham and Parks (1986), and thicknesses of the confining bed penetrated by each test hole, a maximum vertical leakage rate was calculated for each test hole site in the well field.

Penetration time for ground water to move through the confining unit was determined by Richardson (1989) to range from 95 years at well M404 (where total aggregate thickness of clay layers were least) to 390 years at well M416 (where aggregate thicknesses were greatest). Therefore, he concluded that leakage from the fluvial deposits could not be the source of ground water causing the water-quality changes at the Davis well field.

Because of the early hypothesis that water-quality changes over time in production well M419 may have resulted from leakage down the outside of the casing of this well and well M414 on the same lots with shallow wells F419 and F414 were pumped to determine if withdrawals from the Memphis aquifer affected water levels in the fluvial deposits. These production wells were pumped at rates of about 1,000 and 1,500 gallons per minute, respectively, for a week at a time for 6 weeks (July 19 to September 3, 1993). Hydrographs for wells F419 and F414 (fig. 9) indicate no changes in water levels in the fluvial deposits aquifer that can be related to leakage down the outside of the casings of wells M419 and M414 during the periods that these production wells were pumped.

\section{Memphis Aquifer}

The Memphis aquifer underlies the northem part of the Mississippi embayment and provides ground water for most domestic, agricultural, commercial, industrial, and municipal supplies in the western part of western Tennessee (Parks and Carmichael, 1990b). Withdrawals from the Memphis aquifer in the Memphis area 


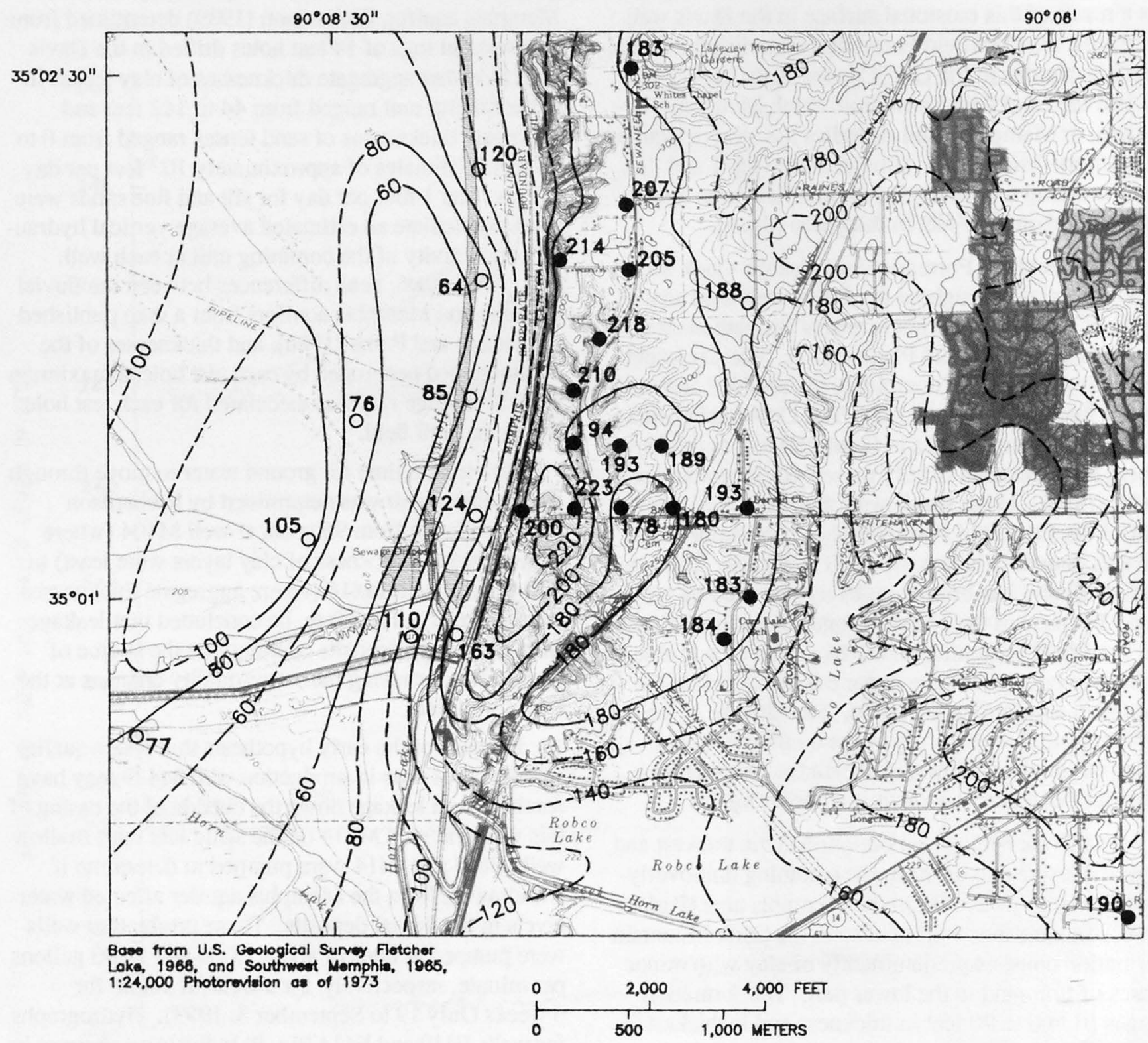

EXPIANATION

-120-- - SUBSURFACE CONTOUR--Shows altitude of the top of the confining unit or Memphis aquifer. Dashed where approximately located. Contour interval 20 feet. Datum is sea level. Contours east of Davis rell field from Parks, 1973

190. TEST HOLE WTHH GEOPHYSICAL LOG USED AS CONTROL--Number is altitude of top of confining unit

77O TEST HOLE WITH IITHOLOGIC LOG USED AS CONTROL--Number is altitude of top of confining unit

Figure 8. Altitude of the erosional surface at the top of the confining unit or Memphis aquifer beneath the alluvial and fluvial deposits aquifers in the Davis well field area, Memphis, Tennessee. 

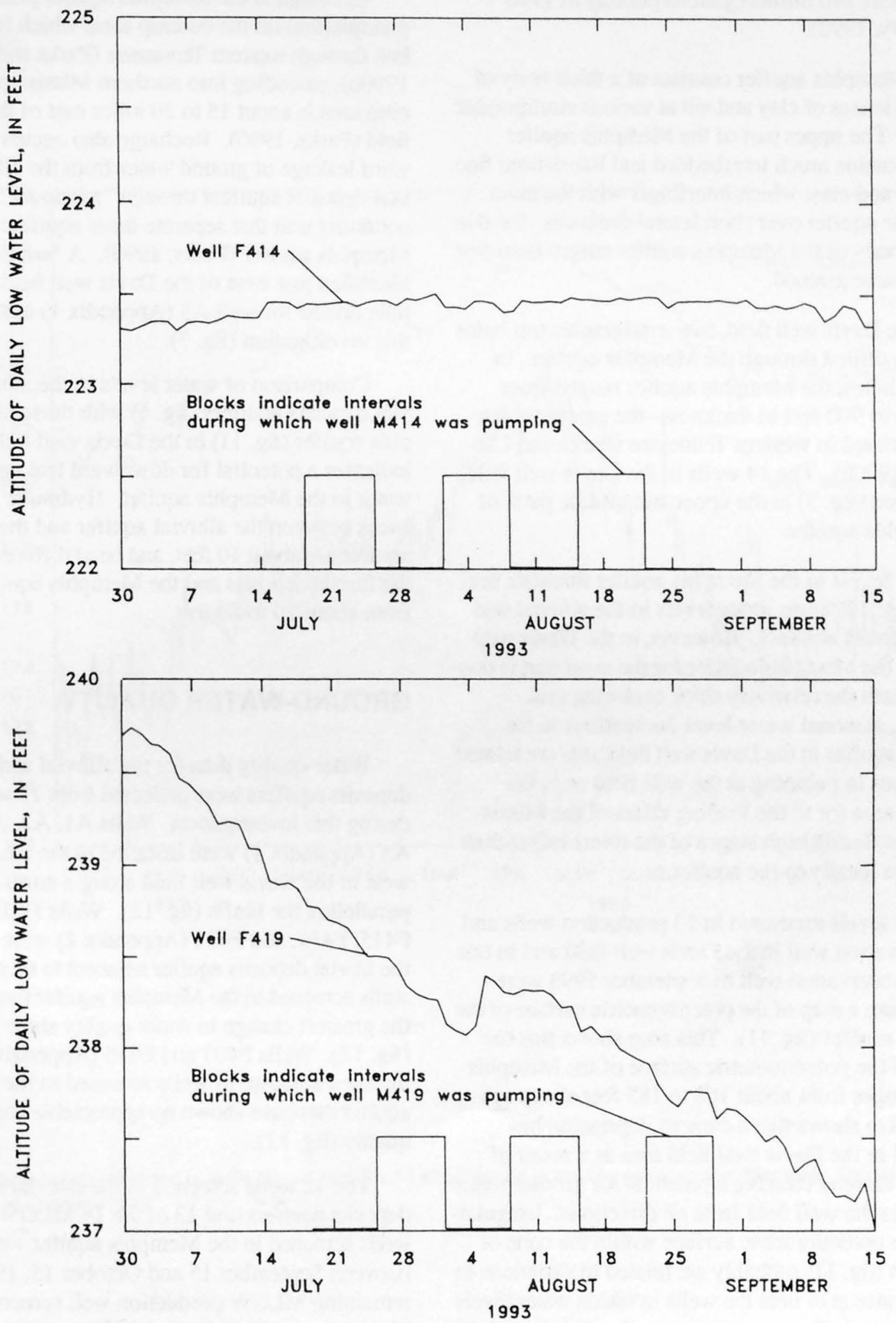

Figure 9. Water levels recorded in wells F414 and F419 screened in the fluvial deposits aquifer, Memphis, Tennessee, July to September 1993, and weekly periods when nearby production wells M414 and M419 were pumped. 
totaled about 196 million gallons per day in 1990 (Kingsbury, 1992).

The Memphis aquifer consists of a thick body of sand with lenses of clay and silt at various stratigraphic horizons. The upper part of the Memphis aquifer locally contains much interbedded and interlensed fine sand, silt, and clay, which interfinger with the main body of the aquifer over short lateral distances. Sand in the main body of the Memphis aquifer ranges from fine to very coarse grained.

At the Davis well field, two stratigraphic test holes have been drilled through the Memphis aquifer. In these test holes, the Memphis aquifer ranged from about 880 to 900 feet in thickness--the greatest thickness penetrated in western Tennessee (Parks and Carmichael, 1990b). The 14 wells in the Davis well field are screened (fig. 3 ) in the upper and middle parts of the Memphis aquifer.

Water levels in the Memphis aquifer fluctuate seasonally (fig. 10) as do water levels in the alluvial and fluvial deposits aquifers. However, in the Davis well field area, the Memphis aquifer for the most part is confined beneath the relatively thick confining unit. Therefore, seasonal water-level fluctuations in the Memphis aquifer in the Davis well field area are related to variations in pumping at the well field or in the Memphis area (or to the loading effect of the Mississippi River during high stages of the river) rather than to recharge locally to the aquifer.

Water levels measured in 13 production wells and one observation well in the Davis well field and in one outlying observation well in September 1993 were used to make a map of the potentiometric surface of the Memphis aquifer (fig. 11). This map shows that the altitude of the potentiometric surface of the Memphis aquifer ranges from about 168 to 185 feet above sea level. It also shows that a cone of depression has developed in the Davis well field area as a result of pumping, thereby creating a potential for ground water to flow into the well field from all directions. Irregularities in the potentiometric surface within the cone of depression (fig. 11) probably are related to variations in pumping rates at or near the wells in which water levels were measured. Pumps on some wells were turned off the afternoon prior to the day of measurement while other wells were pumped to maintain production at the well field. All wells were measured within a 2-day period.
Recharge to the Memphis aquifer primarily is from precipitation on the outcrop area, which forms a broad belt through western Tennessee (Parks and Carmichael, 1990b), extending into northem Mississippi. This outcrop area is about 15 to 20 miles east of the Davis well field (Parks, 1990). Recharge also occurs by downward leakage of ground water from the alluvial and fluvial deposits aquifers through "windows" in the confining unit that separate these aquifers from the Memphis aquifer (Parks, 1990). A "window" was identified just west of the Davis well field in the test hole drilled for well A3 (Appendix 1) installed during this investigation (fig. 3).

Comparison of water levels in the alluvial and fluvial deposits aquifers (fig. 6) with those in the Memphis aquifer (fig. 11) in the Davis well field area indicates a potential for downward leakage of ground water to the Memphis aquifer. Hydraulic head differences between the alluvial aquifer and the Memphis aquifer are about 10 feet, and head differences between the fluvial deposits and the Memphis aquifer range from about 20 to 80 feet.

\section{GROUND-WATER QUALITY}

Water-quality data for the alluvial and fluvial deposits aquifers were collected from 12 wells installed during this investigation. Wells $\mathrm{A} 1, \mathrm{~A} 2, \mathrm{~A} 3, \mathrm{~A} 4$, and A5 (Appendix 1) were installed in the alluvial aquifer west of the Davis well field along a north-south line paralleling the bluffs (fig. 12). Wells F401, F414, F415, F419, and F421 (Appendix 1) were installed in the fluvial deposits aquifer adjacent to those production wells screened in the Memphis aquifer that have shown the greatest change in water quality since 1972

(fig. 12). Wells F403 and F416 (Appendix 1) were installed adjacent to wells screened in the Memphis aquifer that have shown no appreciable change in water quality (fig. 12).

The 12 wells screened in the alluvial and fluvial deposits aquifers and 13 of the 14 MLGW production wells screened in the Memphis aquifer were sampled between September 15 and October 15, 1992. The remaining MLGW production well screened in the Memphis aquifer (M417), which was out-of-service during the initial sampling period, was sampled on December 2, 1992. These water samples were analyzed for water-quality properties and major inorganic and trace element constituents at the USGS National 


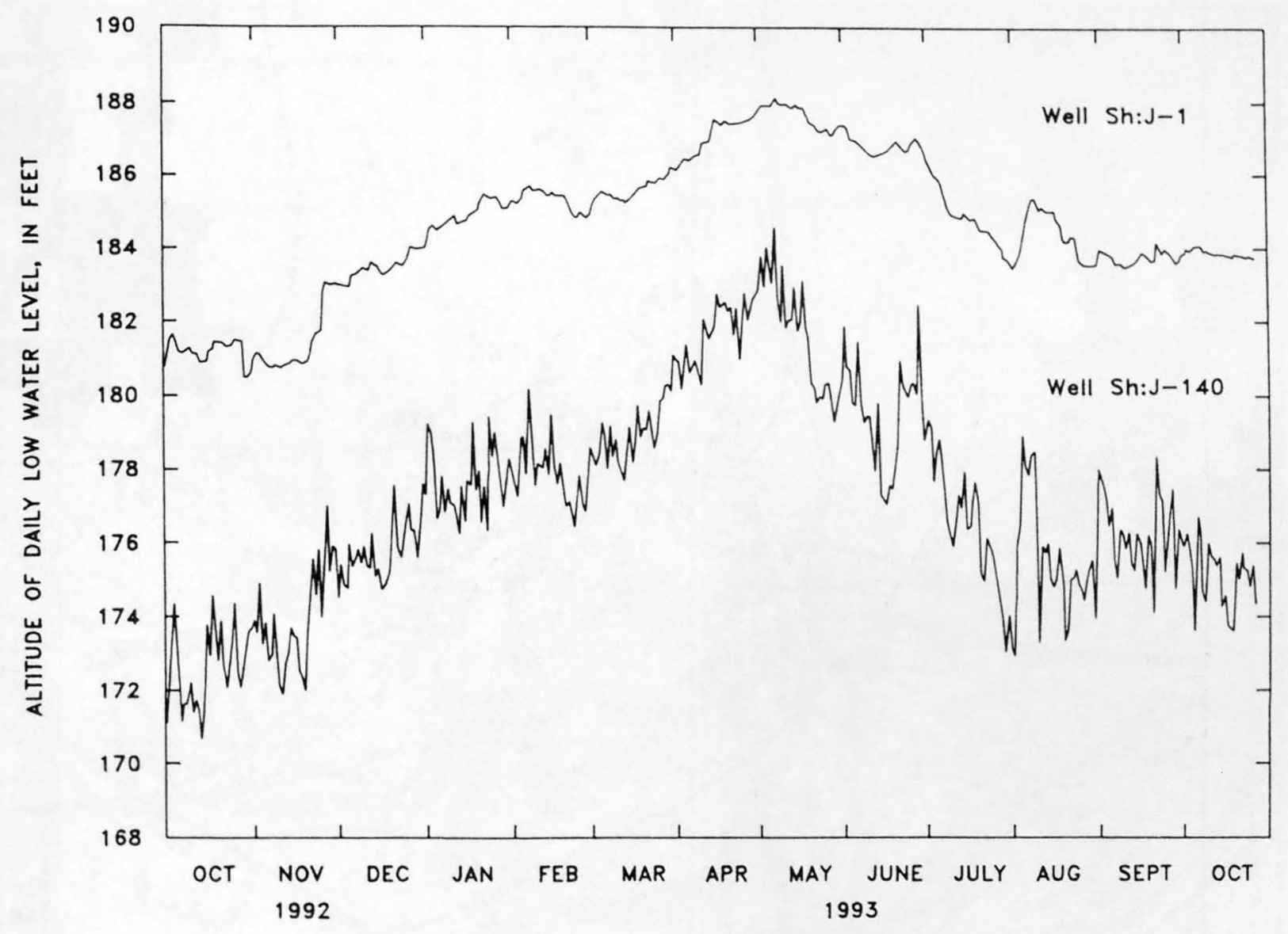

Figure 10. Water levels recorded in wells Sh:J-1 and Sh:J-140 screened in the Memphis aquifer, Memphis, Tennessee, October 1992 to October 1993. 


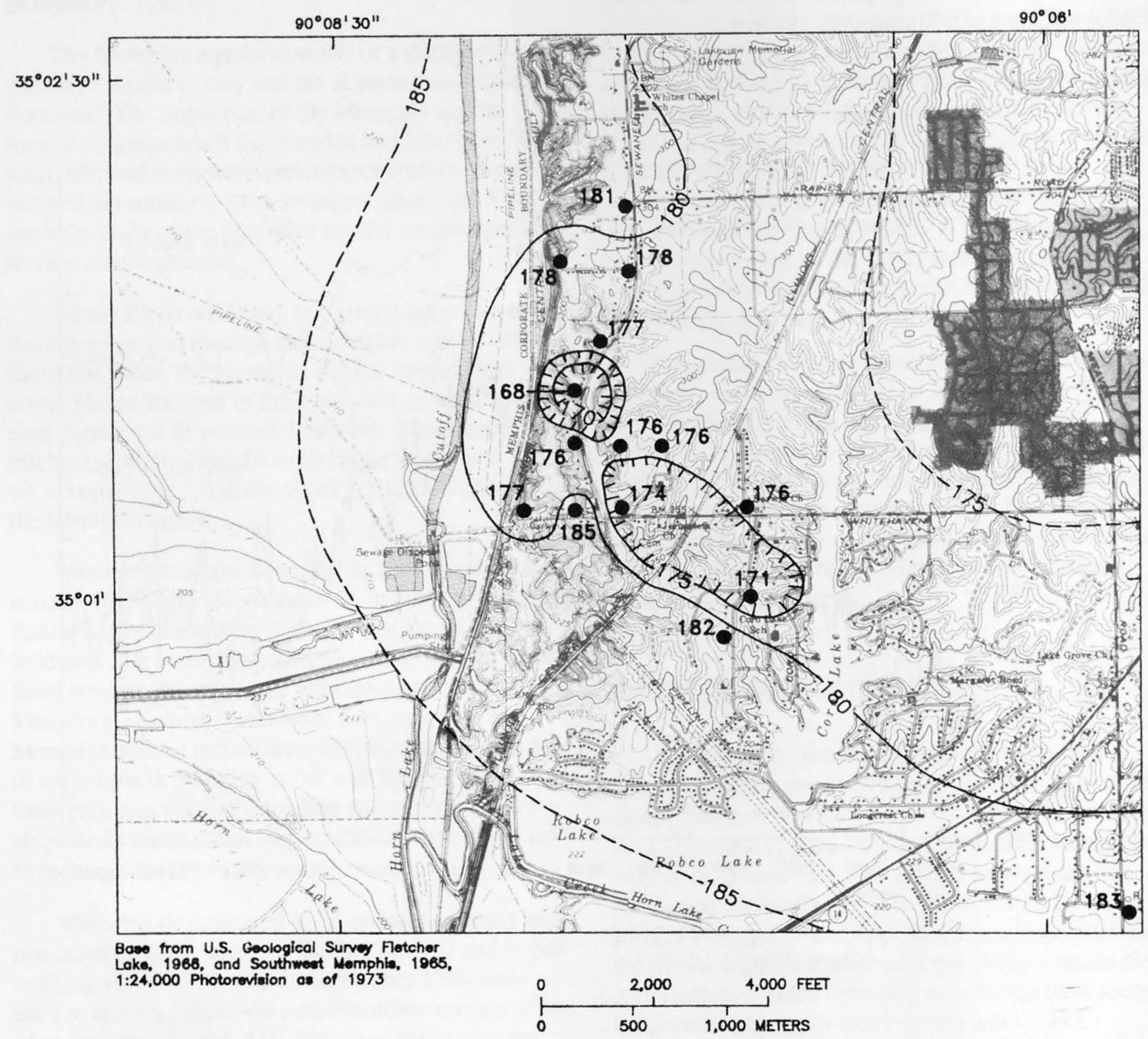

\section{EXPLANATION}

-185-- - POTENTTOMETRIC CONTOUR--Shows altitude at which water would have stood in tightly cased wells. Dashed where approximately located. Hachures indicate depression. Contour interval 5 feet. Datum is sea level is water-level altitude

Figure 11. Altitude of potentiometric surface of the Memphis aquifer, in the Davis well field area, Memphis, Tennessee, September 1993. 


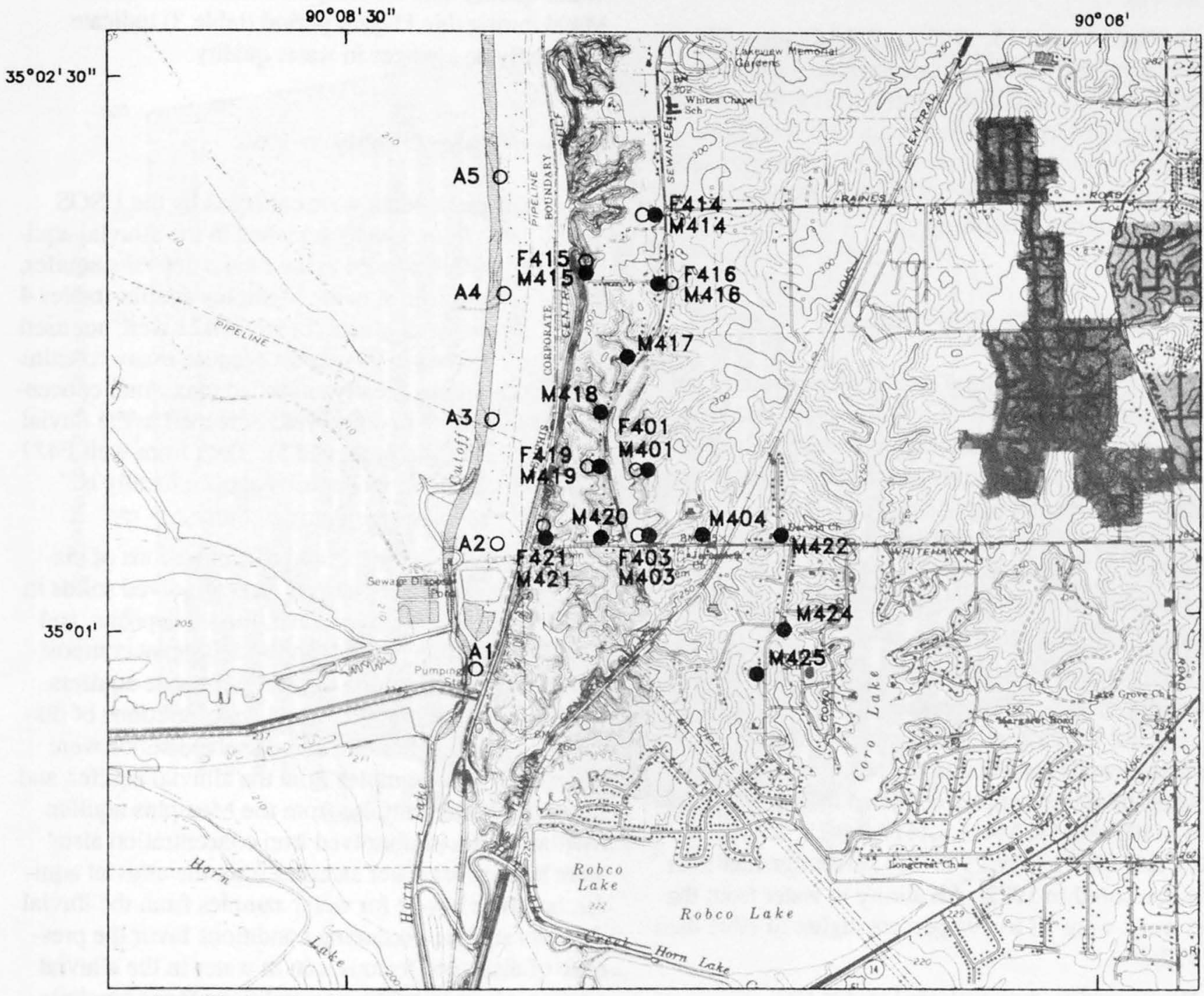

Base from U.S. Geological Survey Flotcher

Loke, 1968, and Southweet Memphis, 1985,

$1: 24,000$ Photorevision as of 1973

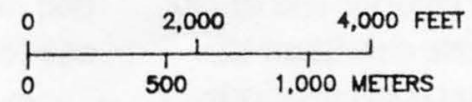

EXPLANATION

\section{OA1 WELL SCREENED IN THE ALLUVIAL OR FLUVIAL DEPOSITS AQUIFER AND NUMBER \\ - M425 WELL SCREENED IN THE MEMPHIS AQUIFER AND NUMBER}

Figure 12. Location of 12 wells screened in the alluvial aquifer and fluvial deposits aquifers and 14 wells screened in the Memphis aquifer that were sampled for water-quality analysis in the Davis well field area, Memphis, Tennessee. 
Water Quality Laboratory (NWQL). In addition, water samples from the 5 wells screened in the alluvial aquifer, the 7 wells in the fluvial deposits aquifer, and 10 of the 14 wells in the Memphis aquifer were analyzed for tritium concentrations and stable carbon-isotope ratios (C13/C12).

On April 14 and 15, 1993, well A3 (screened in the alluvial aquifer), well F419 (screened in the fluvial deposits aquifer), and wells M404, M414, M416, and M419 (screened in the Memphis aquifer) were sampled to determine chlorofluorocarbon (CFC) concentrations. The samples were analyzed at a USGS National Research Program laboratory.

\section{Historical Water-Quality Changes}

Hardness and alkalinity and concentrations of sulfate, chloride, and dissolved iron were measured by MLGW in water samples collected periodically from the 14 production wells screened in the Memphis aquifer at the Davis well field from 1972 to 1991

(Appendix 2). These data, although incomplete for the years 1974 to 1981 and 1984 to 1986 , provide a 20year perspective of water-quality changes in the Memphis aquifer at the well field.

Water-quality data provided by MLGW (Appendix 2) indicate increasing trends of hardness (fig. 13) and alkalinity in water samples from 8 of 14 production wells screened in the Memphis aquifer. Hardness of water samples collected in 1991 from wells M401, M414, M415, M417, M418, M419, M420, and M421 were 29 to 224 percent greater than those measured in 1972. Alkalinity in water from the same wells were 33 to 194 percent higher in 1991 than in 1972.

Water-quality data collected by MLGW (Appendix 2) for concentrations of chloride and sulfate vary considerably and do not indicate consistent temporal trends. Large increases in iron concentrations were measured in water from several wells, particularly well M419. However, increasing trends in iron concentration are not well defined.

The USGS sampled well M404 in the Davis well field annually from 1980 to 1991 in conjunction with a USGS-MLGW data-collection program to monitor water quality in the Memphis aquifer at MLGW and selected industrial well fields in the Memphis area. These samples were analyzed for water-quality properties and major inorganic and trace element constituents (table 3). Well M404 was included in the datacollection program to monitor the water quality at the Davis well field because it is upgradient in the general direction of ground-water flow into the well field from the regional recharge area of the Memphis aquifer. Water-quality data for samples collected from well M404 during this 11-year period (table 3) indicate essentially no changes in water quality.

\section{Ground-Water Quality in 1992}

Water-quality data were collected by the USGS during 1992 from 5 wells screened in the alluvial aquifer, seven wells screened in the fluvial deposits aquifer, and 14 wells screened in the Memphis aquifer (tables 4 and 5). Water-quality data for well F421 were not used in analysis of data in this report because many constituent concentrations greatly exceeded maximum concentrations measured in other wells screened in the fluvial deposits aquifer (tables 4 and 5). Data from well F421 indicate that the fluvial deposits aquifer locally is contaminated from an unknown source.

Box plots of hardness and concentrations of dissolved strontium, iron, barium, and dissolved solids in water samples from the alluvial, fluvial deposits, and Memphis aquifers (fig. 14) show significant compositional differences among waters from these aquifers. Median values for hardness and concentrations of dissolved strontium, barium, and dissolved solids were highest for water samples from the alluvial aquifer, and lowest for water samples from the Memphis aquifer. Median values of dissolved iron concentration also were highest for water samples from the alluvial aquifer, but were lowest for water samples from the fluvial deposits aquifer. Reducing conditions favor the presence of dissolved ferrous iron in water in the alluvial aquifer, whereas oxidizing conditions favor precipitation of ferric iron in water in the fluvial deposits aquifer.

The quality of water collected from some production wells screened in the Memphis aquifer at the Davis well field has been affected by leakage of more highly mineralized water into the well field from another aquifer. For the purposes of this report, water samples from the Memphis aquifer were interpreted as "unaffected" or "affected" by comparing 1980 to 1991 water-quality data for well M404 (table 3) with the 1992 data for the 13 other production wells in the Davis well field (tables 4 and 5). Water-quality data from M404 prior to 1992 (table 3) was assumed to represent unaffected 
HARDNESS

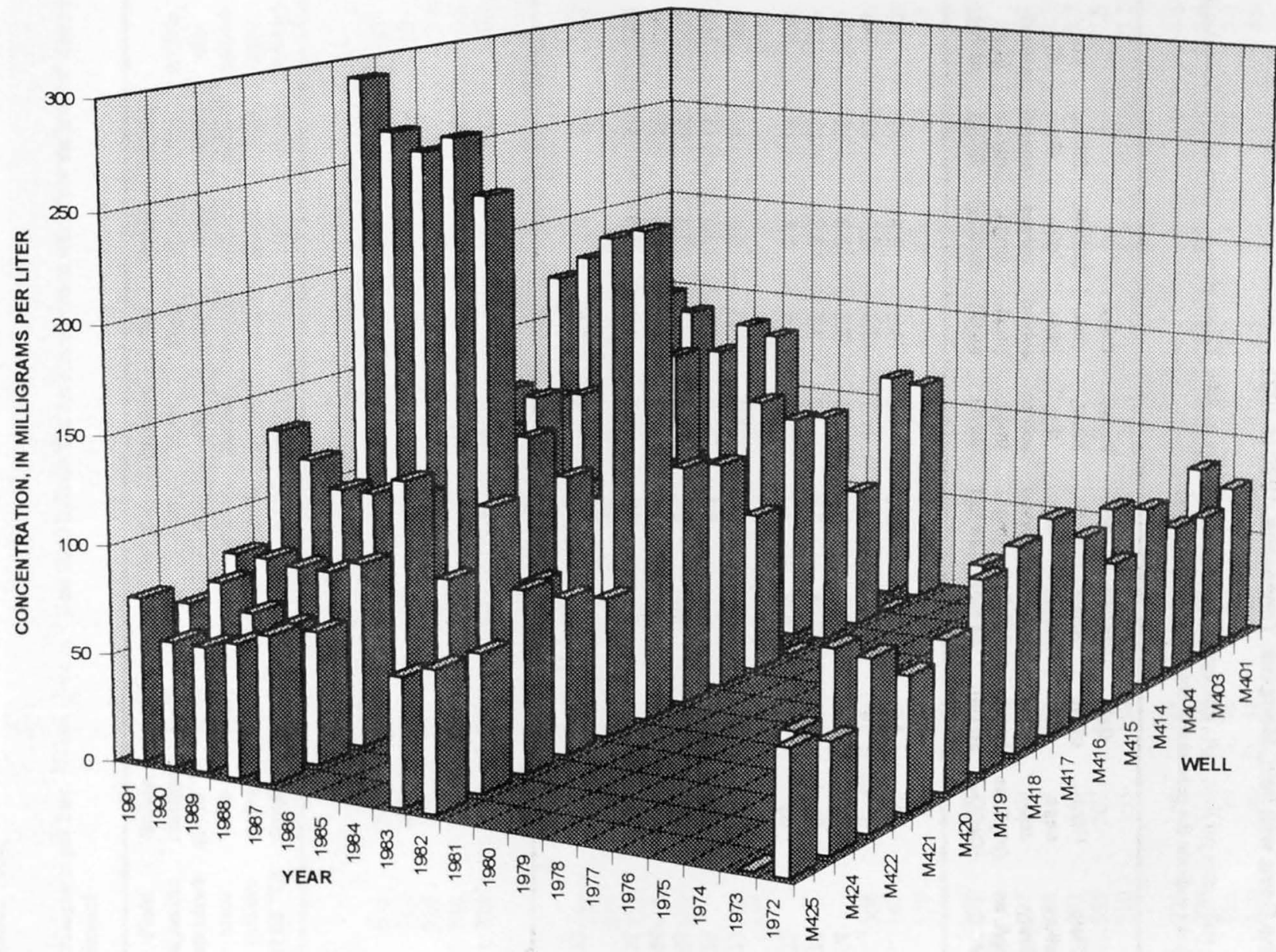

Figure 13. Hardness of water from 14 wells screened in the Memphis aquifer at the Davis well Field, Memphis, Tennessee, 1972 to 1991 
\& Table 3. Water-quality properties and selected major inorganic and trace element constituent concentrations analyzed by the U.S. Geological Survey in samples from well M404 screened in the Memphis aquifer at the Davis well field, Memphis, Tennessee, 1980 to 1991

$\left[{ }^{\circ} \mathrm{C}\right.$, degrees Celsius; $\mu \mathrm{S} / \mathrm{cm}$, microsiemens per centimeter, $\mathrm{mg} / \mathrm{L}$, milligrams per liter, $\mu \mathrm{g} / \mathrm{L}$, micrograms per liter, - , indicates no data. Values given as $<$ (less than) indicate that the concentration was below the level of detection for the analytical method used and do not indicate the presence or absence of a constituent]

\begin{tabular}{|c|c|c|c|c|c|c|c|c|c|c|c|c|c|c|c|c|}
\hline $\begin{array}{c}\text { Date } \\
\text { sampled }\end{array}$ & $\begin{array}{l}\text { Field } \\
\text { temper- } \\
\text { ature } \\
\text { water } \\
\left({ }^{\circ} \mathrm{C}\right)\end{array}$ & $\begin{array}{l}\text { Field } \\
\text { pH } \\
\text { (stand- } \\
\text { ard } \\
\text { units) }\end{array}$ & $\begin{array}{c}\text { Field } \\
\text { specific } \\
\text { conduct- } \\
\text { ance } \\
(\mu \mathrm{S} / \mathrm{cm} \\
\left.\text { at } 25^{\circ} \mathrm{C}\right)\end{array}$ & $\begin{array}{l}\text { Sollds, } \\
\text { residue } \\
\text { at } 180^{\circ} \mathrm{C} \\
\text { dis- } \\
\text { solved } \\
\text { (mgl) }\end{array}$ & $\begin{array}{l}\text { Field } \\
\text { alka- } \\
\text { linity } \\
(\mathrm{mg} / \mathrm{L} \text { as } \\
\left.\mathrm{CaCO}_{3}\right)\end{array}$ & $\begin{array}{l}\text { Hard- } \\
\text { ness, } \\
\text { total } \\
(\mathrm{mg} / \mathrm{L} \text { as } \\
\left(\mathrm{CaCO}_{3}\right)\end{array}$ & $\begin{array}{l}\text { Cal- } \\
\text { cium, } \\
\text { dis- } \\
\text { solved } \\
\text { (mgh } \\
\text { as Ca) }\end{array}$ & $\begin{array}{l}\text { Magne- } \\
\text { slum, } \\
\text { dis- } \\
\text { solved } \\
\text { (mg/L } \\
\text { as Mg) }\end{array}$ & $\begin{array}{l}\text { So- } \\
\text { dium, } \\
\text { dis- } \\
\text { solved } \\
\text { (mgh } \\
\text { as } \mathrm{Na} \text { ) }\end{array}$ & $\begin{array}{l}\text { Potas- } \\
\text { slum, } \\
\text { dis- } \\
\text { solved } \\
\text { (mgh } \\
\text { as K) }\end{array}$ & $\begin{array}{l}\text { Chlo- } \\
\text { ride, } \\
\text { dis- } \\
\text { solved } \\
\text { (mghl } \\
\text { as Cl) }\end{array}$ & $\begin{array}{l}\text { Sulfate, } \\
\text { dis- } \\
\text { solved } \\
\text { (mgll } \\
\text { as } \mathrm{SO}_{4} \text { ) }\end{array}$ & $\begin{array}{l}\text { Sillica, } \\
\text { dis- } \\
\text { solved } \\
\left(\mathrm{mg}^{2} \mathrm{~L} \text { as }\right. \\
\left.\mathrm{SiO}_{2}\right)\end{array}$ & $\begin{array}{l}\text { Iron, } \\
\text { dis- } \\
\text { solved } \\
(\mu \mathrm{g} / \mathrm{L} \\
\text { as } \mathrm{Fe} \text { ) }\end{array}$ & $\begin{array}{l}\text { Manga- } \\
\text { nese, } \\
\text { dis- } \\
\text { solved } \\
\text { ( } \mu \mathrm{g} / \mathrm{L} \\
\text { as Mn) }\end{array}$ & $\begin{array}{l}\text { Bar- } \\
\text { lum, } \\
\text { dis- } \\
\text { solved } \\
\text { ( } \mu \mathrm{g} / \mathrm{L} \\
\text { as Ba) }\end{array}$ \\
\hline $09-03-80$ & 18.0 & 6.4 & 155 & -- & -. & 65 & 14 & 7.2 & 8.0 & 0.8 & 3.3 & 2.4 & 17 & 350 & 10 & -. \\
\hline $09-23-81$ & 17.5 & 6.1 & 170 & 95 & -- & 63 & 14 & 6.7 & 7.8 & .7 & 3.4 & 2.3 & 13 & 340 & $<10$ & 100 \\
\hline $08-25-82$ & 18.0 & 6.3 & 153 & 90 & 74 & 63 & 14 & 6.7 & 7.4 & 6 & 3.2 & 3.0 & 15 & 360 & 5 & 48 \\
\hline $08-22-84$ & 18.0 & 6.3 & 142 & 85 & 70 & 56 & 12 & 6.3 & 7.8 & .7 & 3.5 & 3.3 & 13 & 180 & 4 & 77 \\
\hline $09-10-85$ & 18.0 & 6.3 & 150 & 86 & 72 & 60 & 13 & 6.6 & 7.7 & 9 & 3.6 & 3.1 & 14 & 300 & 3 & 52 \\
\hline $08-26-86$ & 18.0 & 6.3 & 145 & 87 & 72 & 59 & 13 & $6.5^{\prime}$ & 8.4 & 1.0 & 3.0 & 3.3 & 14 & 290 & 5 & 48 \\
\hline $08-24-87$ & 17.5 & 6.4 & 150 & 87 & 73 & 60 & 13 & 6.6 & 8.1 & .9 & 3.1 & 3.3 & 15 & 310 & 6 & 38 \\
\hline $08-08-88$ & 18.0 & 6.3 & 160 & 91 & 68 & 60 & 13 & 6.7 & 8.2 & .8 & 3.1 & 3.4 & 14 & 280 & 9 & 40 \\
\hline $08-22-89$ & 18.0 & 6.4 & 158 & 93 & 84 & 59 & 13 & 6.5 & 8.3 & .9 & 3.2 & 3.0 & 15 & 300 & 4 & 50 \\
\hline $08-13-90$ & 17.5 & 6.4 & 137 & 82 & 74 & 59 & 13 & 6.5 & 8.2 & .8 & 3.9 & 2.9 & 14 & 250 & 6 & 43 \\
\hline $08-08-91$ & 17.4 & 6.3 & 155 & 87 & 73 & 63 & 14 & 6.7 & 8.3 & 1.0 & 3.8 & 2.7 & 15 & 290 & 4 & 41 \\
\hline
\end{tabular}


Table 4. Water-quality properties and major inorganic constituent concentrations in samples from 26 wells screened in the alluvial, fluvial deposits, and Memphis aquifers in the Davis well field area, Memphis, Tennessee, 1992

$\left[{ }^{\circ} \mathrm{C}\right.$, degrees Celsius; $\mu \mathrm{S} / \mathrm{cm}$, microsiemens per centimeter, $\mathrm{mg} / \mathrm{L}$, milligrams per liter. Values given as < (less than) indicate that the concentration was below the level of detection for the analytical method used and do not indicate the presence or absence of a constituent]

\begin{tabular}{|c|c|c|c|c|c|c|c|c|c|c|c|c|c|c|c|c|}
\hline $\begin{array}{l}\text { Well } \\
\text { Project } \\
\text { and } \\
\text { map }\end{array}$ & $\begin{array}{l}\text { Umbers } \\
\text { USGS local } \\
\text { for } \\
\text { Tonnessee }\end{array}$ & $\begin{array}{c}\text { Date } \\
\text { sampled }\end{array}$ & $\begin{array}{l}\text { Fleld } \\
\text { temper- } \\
\text { ature } \\
\text { water } \\
\left({ }^{\circ} \mathrm{C}\right)\end{array}$ & $\begin{array}{l}\text { Fleid } \\
\text { pH } \\
\text { (stand- } \\
\text { ard } \\
\text { units) }\end{array}$ & $\begin{array}{c}\text { Fleid } \\
\text { specific } \\
\text { conduct- } \\
\text { ance } \\
(\mu \mathrm{S} / \mathrm{cm} \\
\text { at } 25^{\circ} \mathrm{C} \text { ) }\end{array}$ & $\begin{array}{l}\text { Sollds, } \\
\text { residue } \\
\text { at } 180^{\circ} \mathrm{C} \\
\text { dls- } \\
\text { solved } \\
\text { (mg/L) }\end{array}$ & $\begin{array}{l}\text { Fleid } \\
\text { alka- } \\
\text { linity } \\
\left(\mathrm{mgl}^{2} \mathrm{as}\right. \\
\left.\mathrm{CaCO}_{3}\right)\end{array}$ & $\begin{array}{l}\text { Hard- } \\
\text { ness, } \\
\text { total } \\
(\mathrm{mg} / \mathrm{L} \text { as } \\
\left.\mathrm{CaCO}_{3}\right)\end{array}$ & $\begin{array}{l}\text { Cal- } \\
\text { clum, } \\
\text { dls- } \\
\text { solved } \\
\text { (mgh } \\
\text { as Ca) }\end{array}$ & $\begin{array}{l}\text { Magne- } \\
\text { slum, } \\
\text { dis- } \\
\text { solved } \\
\text { (mgh } \\
\text { as Mg) }\end{array}$ & $\begin{array}{l}\text { So- } \\
\text { dium, } \\
\text { dis- } \\
\text { solved } \\
\text { (mgh } \\
\text { as } \mathrm{Na} \text { ) }\end{array}$ & $\begin{array}{l}\text { Potas- } \\
\text { sium, } \\
\text { dls- } \\
\text { solved } \\
\text { (mgh } \\
\text { as K) }\end{array}$ & $\begin{array}{l}\text { Chlo } \\
\text { ride, } \\
\text { dls- } \\
\text { solved } \\
\text { (mgh } \\
\text { as Cl) }\end{array}$ & $\begin{array}{l}\text { Sulfate, } \\
\text { dlis- } \\
\text { solved } \\
(\mathrm{mgh} \\
\left.\text { as } \mathrm{SO}_{4}\right)\end{array}$ & $\begin{array}{l}\text { Fluo- } \\
\text { ride, } \\
\text { dls- } \\
\text { solved } \\
\text { (mgh } \\
\text { as F) }\end{array}$ & $\begin{array}{l}\text { Sllica, } \\
\text { dis- } \\
\text { solved } \\
\text { (mgh } \\
\text { as } \mathrm{SiO}_{2} \text { ) }\end{array}$ \\
\hline \multicolumn{17}{|c|}{ Alluvial aquifer } \\
\hline A1 & Sh:H-17 & $09-17-92$ & 18.3 & 6.9 & 865 & 505 & 462 & 460 & 110 & 46 & 10 & 1.9 & 6.8 & 40 & 0.3 & 27 \\
\hline A2 & Sh:H-18 & $09-17-92$ & 16.8 & 7.0 & 760 & 407 & 440 & 370 & 91 & 34 & 19 & 2.8 & 9.6 & 19 & 0.2 & 20 \\
\hline A3 & Sh:H-19 & $09-16-92$ & 17.3 & 7.0 & 910 & 507 & 532 & 460 & 110 & 45 & 22 & 2.7 & 10 & 1.8 & 0.3 & 27 \\
\hline A4 & Sh:H-20 & $09-16-92$ & 17.1 & 7.1 & 784 & 440 & 444 & 380 & 89 & 38 & 16 & 3.3 & 4.2 & 0.3 & 0.3 & 27 \\
\hline A5 & Sh:H-21 & $09-15-92$ & 17.3 & 6.9 & 715 & 399 & 406 & 370 & 81 & 40 & 13 & 1.5 & 8.5 & 0.7 & 0.3 & 24 \\
\hline \multicolumn{17}{|c|}{ Fluvial deposits aquifer } \\
\hline F401 & Sh:J-189 & $09-28-92$ & 17.5 & 7.4 & 587 & 322 & 332 & 290 & 63 & 32 & 13 & 3.2 & 2.9 & 6.5 & 0.5 & 18 \\
\hline F403 & Sh:J-188 & $09-28-92$ & 17.8 & 7.5 & 815 & 451 & 432 & 400 & 83 & 46 & 25 & 0.3 & 12 & 13 & 0.3 & 18 \\
\hline F414 & Sh:J-191 & $09-24-92$ & 18.1 & 7.0 & 522 & 296 & 250 & 210 & 46 & 23 & 31 & 1.3 & 4.4 & 23 & 0.3 & 23 \\
\hline F415 & $\mathrm{Sh}: \mathrm{H}-23$ & $10-06-92$ & 27.9 & 7.0 & 627 & 347 & 306 & 280 & 61 & 32 & 16 & 0.8 & 8.4 & 9 & 0.3 & 24 \\
\hline F416 & Sh:J-190 & $09-22-92$ & 17.5 & 7.2 & 551 & 343 & 296 & 300 & 64 & 33 & 13 & 0.7 & 9.6 & 20 & 0.2 & 23 \\
\hline F419 & Sh:H-22 & $09-24-92$ & 16.1 & 7.1 & 638 & 342 & 344 & 330 & 71 & 36 & 9.5 & 0.7 & 4 & 6.3 & 0.1 & 17 \\
\hline F421 & Sh:H-24 & $10-15-92$ & 28.4 & 7.1 & 1,615 & 1,040 & 604 & 700 & 140 & 84 & 91 & 1.6 & 93 & 200 & 0.3 & 19 \\
\hline
\end{tabular}

\begin{tabular}{|c|c|c|c|c|c|c|c|c|c|c|c|c|c|c|c|c|}
\hline M401 & Sh:J-143 & $10-01-92$ & 17.1 & 6.6 & 308 & 169 & 158 & 140 & 31 & 16 & 8.7 & 1.0 & 3.8 & 6.0 & 0.2 & 17 \\
\hline M403 & Sh:H-10 & $09-30-92$ & 17.6 & 6.2 & 167 & 92 & 78 & 65 & 15 & 6.7 & 8.4 & 1.0 & 4.3 & 3.8 & 0.1 & 12 \\
\hline M404 & Sh:J-146 & $09-30-92$ & 17.3 & 6.7 & 159 & 92 & 79 & 63 & 14 & 6.8 & 8.0 & 0.9 & 4.0 & 2.8 & 0.1 & 14 \\
\hline M414 & Sh:J-145 & $10-02-92$ & 17.0 & 6.8 & 374 & 214 & 190 & 170 & 38 & 19 & 9 & 1.3 & 4.4 & 9.5 & 0.2 & 13 \\
\hline M415 & Sh:H-8 & $10-01-92$ & 17.7 & 6.6 & 291 & 157 & 147 & 130 & 30 & 13 & 9.5 & 1.3 & 3.3 & 2.7 & 0.1 & 10 \\
\hline M416 & Sh:J-137 & $10-08-92$ & 17.4 & 6.7 & 191 & 110 & 98 & 74 & 17 & 7.7 & 8.5 & 1.1 & 2.8 & 2.3 & 0.1 & 12 \\
\hline M417 & Sh:H-7 & $12-02-92$ & 16.5 & 6.8 & 388 & 205 & 208 & 190 & 42 & 20 & 10 & 1.6 & 3.3 & 2.1 & 0.2 & 13 \\
\hline M418 & Sh:H-6 & $10-01-92$ & 17.7 & 6.7 & 291 & 156 & 150 & 130 & 30 & 14 & 9.6 & 1.1 & 3.5 & 2.7 & 0.1 & 12 \\
\hline M419 & Sh:H-5 & $10-02-92$ & 17.0 & 6.9 & 555 & 307 & 300 & 270 & 58 & 30 & 11 & 1.2 & 4.2 & 7.3 & 0.3 & 15 \\
\hline M420 & Sh:H-11 & $10-07-92$ & 17.4 & 6.6 & 310 & 165 & 158 & 132 & 30 & 14 & 9.5 & 1.3 & 4.9 & 5.1 & 0.1 & 12 \\
\hline M421 & Sh:H-9 & $10-07-92$ & 17.6 & 6.8 & 291 & 152 & 145 & 120 & 28 & 12 & 10 & 1.4 & 4.0 & 4.5 & 0.1 & 11 \\
\hline M422 & Sh:J-141 & $09-30-92$ & 17.0 & 6.7 & 193 & 113 & 94 & 83 & 18 & 9.2 & 8.1 & 0.7 & 4.3 & 2.6 & 0.1 & 19 \\
\hline M424 & Sh:J-139 & $09-29-92$ & 16.8 & 6.3 & 158 & 96 & 74 & 61 & 14 & 6.2 & 8.4 & 1.1 & 3.2 & 2.8 & 0.1 & 13 \\
\hline M425 & Sh:J-144 & $09-29-92$ & 17.2 & 6.1 & 149 & 89 & 71 & 56 & 13 & 5.7 & 8.5 & 1.0 & 3.2 & 3.0 & 0.1 & 12 \\
\hline
\end{tabular}


Table 5. Trace inorganic constituent concentrations in water from 26 wells screened in the alluvial, fluvial deposits, and Memphis aquifers in the Davis well field area, Memphis, Tennessee, 1992

$[\mu \mathrm{g} / \mathrm{L}$, micrograms per liter. Values given as < (less than) indicate that the concentration was below the level of detection for the analytical method used and do not indicate the presence or absence of a constituent]

\begin{tabular}{|c|c|c|c|c|c|c|c|c|c|c|c|c|c|c|}
\hline Well numbers & $\begin{array}{l}\text { Uumbers } \\
\text { USGS local } \\
\text { for } \\
\text { Tennessee }\end{array}$ & $\begin{array}{c}\text { Date } \\
\text { sampled }\end{array}$ & $\begin{array}{c}\text { Bar- } \\
\text { lum, } \\
\text { dis- } \\
\text { solved } \\
\text { ( } \mu \mathrm{g} / \mathrm{L} \\
\text { as Ba) }\end{array}$ & $\begin{array}{l}\text { Cobalt, } \\
\text { dls- } \\
\text { solved } \\
(\mu g / L \\
\text { as Co) }\end{array}$ & $\begin{array}{l}\text { Iron, } \\
\text { dis- } \\
\text { solved } \\
(\mu g / L \\
\text { as } \mathrm{Fe} \text { ) }\end{array}$ & $\begin{array}{l}\text { Manga- } \\
\text { nese, } \\
\text { dis- } \\
\text { solved } \\
\text { ( } \mu \mathrm{g} / \mathrm{L} \\
\text { as } \mathrm{Mn} \text { ) }\end{array}$ & $\begin{array}{c}\text { Molyb- } \\
\text { denum, } \\
\text { dis- } \\
\text { solved } \\
\text { ( } \mu \mathrm{g} / \mathrm{L} \\
\text { as Mo) }\end{array}$ & $\begin{array}{l}\text { Nickel, } \\
\text { dis- } \\
\text { solved } \\
(\mu \mathrm{g} / \mathrm{L} \\
\text { as } \mathrm{NI})\end{array}$ & $\begin{array}{l}\text { Silver, } \\
\text { dls- } \\
\text { solved } \\
(\mu \mathrm{g} / \\
\text { as Ag) }\end{array}$ & $\begin{array}{l}\text { Stron- } \\
\text { tlum, } \\
\text { dls- } \\
\text { solved } \\
\text { ( } \mu \mathrm{g} / \mathrm{L} \\
\text { as } \mathrm{Sr} \text { ) }\end{array}$ & $\begin{array}{l}\text { Vana- } \\
\text { dium, } \\
\text { dis- } \\
\text { solved } \\
\text { ( } \mu g / L \\
\text { as V) }\end{array}$ & $\begin{array}{c}\text { Alu- } \\
\text { minum, } \\
\text { dis- } \\
\text { solved } \\
\text { ( } \mu \text { g/L } \\
\text { as Al) }\end{array}$ & $\begin{array}{l}\text { Lith- } \\
\text { lum, } \\
\text { dis- } \\
\text { solved } \\
\text { ( } \mu \mathrm{g} / \mathrm{L} \\
\text { as } \mathrm{LI} \text { ) }\end{array}$ & $\begin{array}{l}\text { Sele- } \\
\text { nium, } \\
\text { dis- } \\
\text { solved } \\
\text { ( } \mu \mathrm{g} / \mathrm{L} \\
\text { as Se) }\end{array}$ \\
\hline & & & \multicolumn{12}{|c|}{ Alluvial aquifer } \\
\hline $\begin{array}{l}\text { A1 } \\
\text { A2 } \\
\text { A3 } \\
\text { A4 } \\
\text { A5 }\end{array}$ & $\begin{array}{l}\text { Sh:H-17 } \\
\text { Sh:H-18 } \\
\text { Sh:H-19 } \\
\text { Sh:H-20 } \\
\text { Sh:H-21 }\end{array}$ & $\begin{array}{l}09-17-92 \\
09-17-92 \\
09-16-92 \\
09-16-92 \\
09-15-92\end{array}$ & $\begin{array}{l}230 \\
460 \\
340 \\
330 \\
330\end{array}$ & $\begin{array}{l}<3 \\
<3 \\
<3 \\
<3 \\
<3\end{array}$ & $\begin{array}{l}1,600 \\
3,800 \\
4,400 \\
8,000 \\
6,600\end{array}$ & $\begin{array}{l}360 \\
480 \\
290 \\
350 \\
420\end{array}$ & $\begin{array}{r}<10 \\
10 \\
<10 \\
<10 \\
<10\end{array}$ & $\begin{array}{r}2 \\
<1 \\
<1 \\
<1 \\
<1\end{array}$ & $\begin{array}{l}<1 \\
<1 \\
<1 \\
<1 \\
<1\end{array}$ & $\begin{array}{l}180 \\
490 \\
360 \\
490 \\
230\end{array}$ & $\begin{array}{l}<6 \\
<6 \\
<6 \\
<6 \\
<6\end{array}$ & $\begin{array}{l}<10 \\
<10 \\
<10 \\
<10 \\
<10\end{array}$ & $\begin{array}{r}13 \\
10 \\
10 \\
9 \\
4\end{array}$ & $\begin{array}{l}<1 \\
<1 \\
<1 \\
<1 \\
<1\end{array}$ \\
\hline & \multicolumn{14}{|c|}{ Fluvial deposits aquifer } \\
\hline $\begin{array}{l}\text { F401 } \\
\text { F403 } \\
\text { F414 } \\
\text { F415 } \\
\text { F416 } \\
\text { F419 }\end{array}$ & $\begin{array}{l}\text { Sh:J-189 } \\
\text { Sh:J-188 } \\
\text { Sh:J-191 } \\
\text { Sh:H-23 } \\
\text { Sh:J-190 } \\
\text { Sh:H-22 }\end{array}$ & $\begin{array}{l}09-28-92 \\
09-28-92 \\
09-24-92 \\
10-06-92 \\
09-22-92 \\
09-24-92\end{array}$ & $\begin{array}{r}31 \\
94 \\
58 \\
89 \\
95 \\
130\end{array}$ & $\begin{array}{l}<3 \\
<3 \\
<3 \\
<3 \\
<3 \\
<3\end{array}$ & $\begin{array}{r}4 \\
33 \\
<3 \\
9 \\
31 \\
33\end{array}$ & $\begin{array}{r}1 \\
2 \\
9 \\
8 \\
17 \\
120\end{array}$ & $\begin{array}{l}<10 \\
<10 \\
<10 \\
<10 \\
<10 \\
<10\end{array}$ & $\begin{array}{r}<1 \\
<1 \\
2 \\
3 \\
1 \\
1\end{array}$ & $\begin{array}{l}<1 \\
<1 \\
<1 \\
<1 \\
<1 \\
<1\end{array}$ & $\begin{array}{r}72 \\
140 \\
110 \\
160 \\
130 \\
170\end{array}$ & $\begin{array}{l}<6 \\
<6 \\
<6 \\
<6 \\
<6 \\
<6\end{array}$ & $\begin{array}{r}<10 \\
10 \\
10 \\
<10 \\
<10 \\
<10\end{array}$ & $\begin{array}{l}<4 \\
<4 \\
<4 \\
<4 \\
<4 \\
<4\end{array}$ & $\begin{array}{r}2 \\
5 \\
<1 \\
<1 \\
1 \\
<1\end{array}$ \\
\hline F421 & \multicolumn{14}{|c|}{ Memphis aquifer } \\
\hline $\begin{array}{l}\text { M401 } \\
\text { M403 } \\
\text { M404 } \\
\text { M414 } \\
\text { M415 }\end{array}$ & $\begin{array}{l}\text { Sh:J-143 } \\
\text { Sh:H-10 } \\
\text { Sh:J-146 } \\
\text { Sh:J-145 } \\
\text { Sh:H-8 }\end{array}$ & $\begin{array}{l}10-01-92 \\
09-30-92 \\
09-30-92 \\
10-02-92 \\
10-01-92\end{array}$ & $\begin{array}{r}74 \\
52 \\
42 \\
140 \\
110\end{array}$ & $\begin{array}{l}<3 \\
<3 \\
<3 \\
<3 \\
<3\end{array}$ & $\begin{array}{r}490 \\
370 \\
270 \\
1,200 \\
1,200\end{array}$ & $\begin{array}{r}7 \\
7 \\
5 \\
19 \\
19\end{array}$ & $\begin{array}{r}10 \\
10 \\
<10 \\
<10 \\
<10\end{array}$ & $\begin{array}{l}<1 \\
<1 \\
<1 \\
<1 \\
<1\end{array}$ & $\begin{array}{l}<1 \\
<1 \\
<1 \\
<1 \\
<1\end{array}$ & $\begin{array}{r}77 \\
51 \\
35 \\
130 \\
100\end{array}$ & $\begin{array}{l}<6 \\
<6 \\
<6 \\
<6 \\
<6\end{array}$ & $\begin{array}{l}<10 \\
<10 \\
<10 \\
<10 \\
<10\end{array}$ & $\begin{array}{l}<4 \\
<4 \\
<4 \\
<4 \\
<4\end{array}$ & $\begin{array}{l}<1 \\
<1 \\
<1 \\
<1 \\
<1\end{array}$ \\
\hline $\begin{array}{l}\text { M416 } \\
\text { M417 } \\
\text { M418 } \\
\text { M419 } \\
\text { M420 }\end{array}$ & $\begin{array}{l}\text { Sh:J-137 } \\
\text { Sh:H-7 } \\
\text { Sh:H-6 } \\
\text { Sh:H-5 } \\
\text { Sh:H-11 }\end{array}$ & $\begin{array}{l}10-08-92 \\
12-02-92 \\
10-01-92 \\
10-02-92 \\
10-07-92\end{array}$ & $\begin{array}{r}80 \\
200 \\
110 \\
130 \\
95\end{array}$ & $\begin{array}{l}<3 \\
<3 \\
<3 \\
<3 \\
<3\end{array}$ & $\begin{array}{r}800 \\
2,400 \\
1,100 \\
5,300 \\
720\end{array}$ & $\begin{array}{l}10 \\
38 \\
15 \\
33 \\
12\end{array}$ & $\begin{array}{l}<10 \\
<10 \\
<10 \\
<10 \\
<10\end{array}$ & $\begin{array}{c}<1 \\
<1 \\
<1 \\
<1 \\
1.9\end{array}$ & $\begin{array}{l}<1 \\
<1 \\
<1 \\
<1 \\
<1\end{array}$ & $\begin{array}{r}62 \\
190 \\
96 \\
150 \\
106\end{array}$ & $\begin{array}{l}<6 \\
<6 \\
<6 \\
<6 \\
<6\end{array}$ & $\begin{array}{r}10 \\
10 \\
<10 \\
<10 \\
<10\end{array}$ & $\begin{array}{l}<4 \\
<4 \\
<4 \\
<4 \\
<4\end{array}$ & $\begin{array}{l}<1 \\
<1 \\
<1 \\
<1 \\
<1\end{array}$ \\
\hline $\begin{array}{l}\text { M421 } \\
\text { M422 } \\
\text { M424 } \\
\text { M425 }\end{array}$ & $\begin{array}{l}\text { Sh:H-9 } \\
\text { Sh:J-141 } \\
\text { Sh:J-139 } \\
\text { Sh:J-144 }\end{array}$ & $\begin{array}{l}10-07-92 \\
09-30-92 \\
09-29-92 \\
09-29-92\end{array}$ & $\begin{array}{l}89 \\
39 \\
68 \\
62\end{array}$ & $\begin{array}{l}<3 \\
<3 \\
<3 \\
<3\end{array}$ & $\begin{array}{l}780 \\
120 \\
590 \\
600\end{array}$ & $\begin{array}{r}11 \\
2 \\
10 \\
9\end{array}$ & $\begin{array}{l}<10 \\
<10 \\
<10 \\
<10\end{array}$ & $\begin{array}{r}<1 \\
<1 \\
1 \\
<1\end{array}$ & $\begin{array}{l}<1 \\
<1 \\
<1 \\
<1\end{array}$ & $\begin{array}{l}80 \\
37 \\
64 \\
52\end{array}$ & $\begin{array}{l}<6 \\
<6 \\
<6 \\
<6\end{array}$ & $\begin{array}{l}<10 \\
<10 \\
<10 \\
<10\end{array}$ & $\begin{array}{l}<4 \\
<4 \\
<4 \\
<4\end{array}$ & $\begin{array}{l}<1 \\
<1 \\
<1 \\
<1\end{array}$ \\
\hline
\end{tabular}


HARDNESS
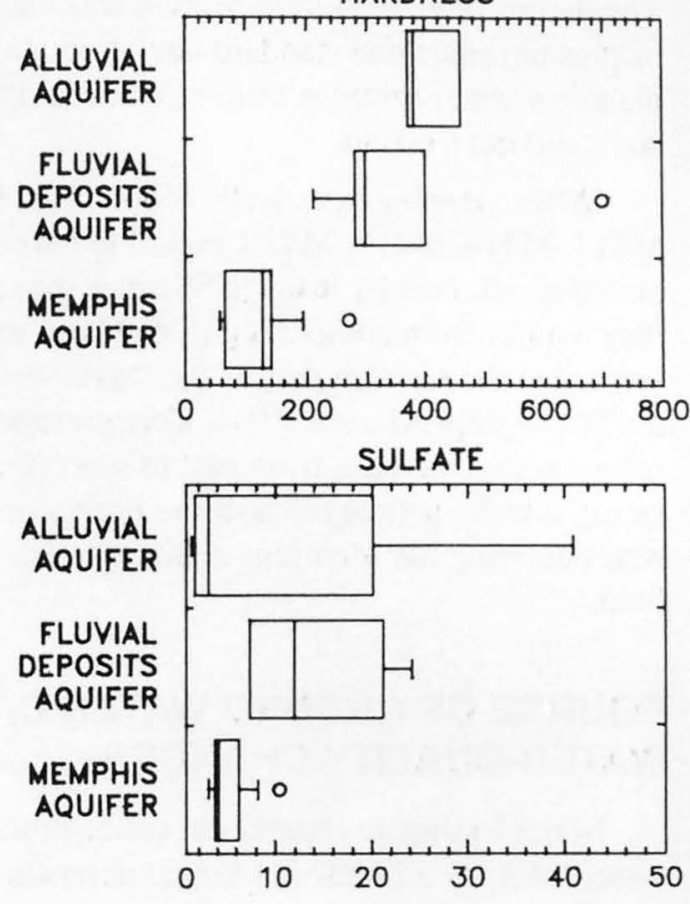

IRON

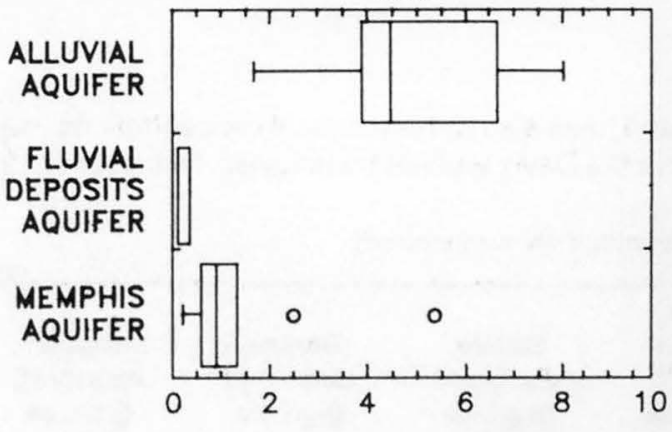

DISSOLVED SOLIDS

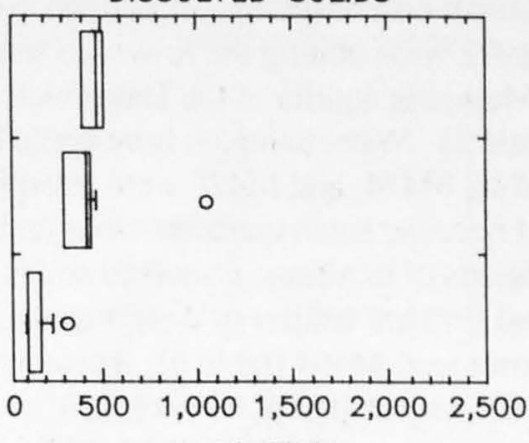

STRONTIUM

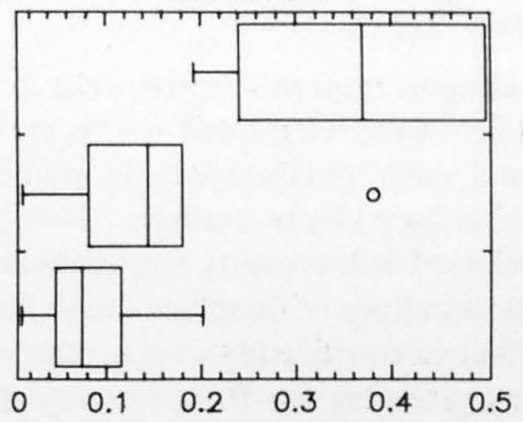

BARIUM

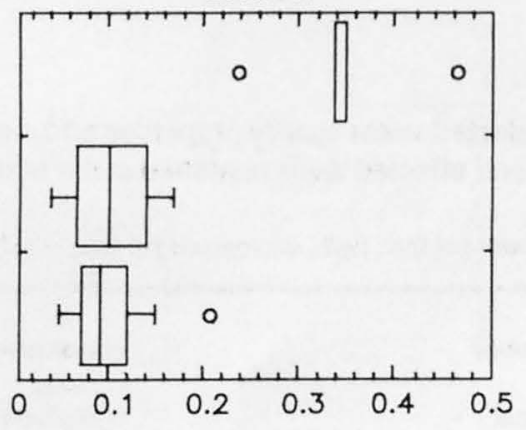

CONCENTRATION, IN MILLIGRAMS PER LITER

\section{EXPLANATION}

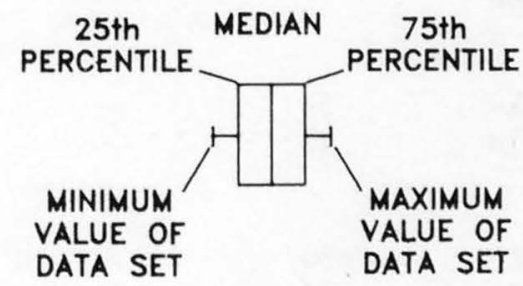

NUMBER OF DATA POINTS USED FOR EACH AQUIFER WERE: ALLUVIAL AQUIFER (5), FLUVIAL DEPOSITS AQUIFER (6), MEMPHIS AQUIF'ER (14)

- REPRESENTS STATISTICAL OUTLIER, NOT INCLUDED IN CALCULATION OF MEDIAN

Figure 14. Selected water-quality properties and major inorganic and trace element constituent concentrations measured in samples from wells screened in the alluvial, fluvial deposits, and Memphis aquifers in the Davis well field area, Memphis, Tennessee, 1992. 
ground water inasmuch as values for hardness and concentrations of dissolved solids, sulfate, barium, and iron did not increase in samples collected from 1980 to 1991 . In addition, water-quality properties and constituent concentrations in samples from well M404 in 1992 were among the lowest in samples from the Memphis aquifer at the Davis well field (tables 4 and 5). Water samples from wells M403, M416, M422, M424, and M425 were interpreted as unaffected because mean concentrations and standard deviations of hardness, dissolved solids, sulfate, barium, and iron are similar to those measured in samples from well M404 (table 6). These wells are located in the eastern part of the well field and are the farthest production wells east from the Mississippi Alluvial Plain (fig. 1).

Water samples from production wells in the Davis well field were interpreted as affected by leakage of ground water into the Memphis aquifer from another aquifer based on two criteria. First, median values of selected water-quality properties and constituent concentrations of dissolved major inorganic and trace element constituents were greater in affected water samples than those in samples from unaffected Memphis aquifer wells (fig. 15). Second, mean values of selected water-quality properties and constituent concentrations were significantly higher in affected Memphis aquifer samples than those in samples from unaffected Memphis aquifer wells (table 6). The definition of significance used was that the ranges of plus or minus one standard deviation about the means of water samples from affected and unaffected wells did not overlap.

Water samples from wells M401, M414, M415, M417, M418, M419, M420, and M421 were interpreted as affected by leakage of water into the Memphis aquifer from another aquifer. These wells are located in the western part of the Davis well field near the Mississippi Alluvial Plain. Concentrations of dissolved solids increase from east to west (fig. 16), indicating that the source of the more highly mineralized water entering the Memphis aquifer is west of the well field.

\section{SOURCE OF GROUND WATER CAUSING WATER-QUALITY CHANGES}

Major inorganic constituent concentrations in water from the alluvial and fluvial deposits aquifers did not provide unequivocal evidence as to which of

Table 6. Selected water-quality properties and major inorganic and trace element constituent concentrations used to determine unaffected and affected wells screened in the Memphis aquifer at the Davis well field, Memphis, Tennessee, 1992

[mg/L, milligrams per liter, $\mu \mathrm{g} / \mathrm{L}$, micrograms per liter, -- indicates that this constituent was not measured]

\begin{tabular}{|c|c|c|c|c|c|c|}
\hline $\begin{array}{c}\text { Well number } \\
\text { and } \\
\text { statistical } \\
\text { parameter }\end{array}$ & $\begin{array}{c}\text { Hardness, } \\
\text { total } \\
(\mathrm{mg} / \mathrm{L} \text { as } \\
\left.\mathrm{CaCO}_{3}\right)\end{array}$ & $\begin{array}{l}\text { Sollids, } \\
\text { residue } \\
\text { at } 180^{\circ} \mathrm{C} \\
\text { dissolved } \\
\text { (mg/L) }\end{array}$ & $\begin{array}{c}\text { Sulfate, } \\
\text { dissolved } \\
(\mathrm{mg} / \mathrm{L} \text { as } \\
\left.\mathrm{SO}_{4}\right)\end{array}$ & $\begin{array}{c}\text { Barlum, } \\
\text { dlssolved } \\
(\mu \mathrm{g} / \mathrm{L} \text { as } \\
\text { Ba) }\end{array}$ & $\begin{array}{c}\text { Strontium, } \\
\text { dlissolved } \\
(\mu \mathrm{g} / \mathrm{L} \text { as } \\
\mathrm{Sr})\end{array}$ & $\begin{array}{c}\text { Iron, } \\
\text { dissolved } \\
(\mu \mathrm{g} / \mathrm{L} \text { as } \\
\text { Fe) }\end{array}$ \\
\hline
\end{tabular}

Unaffected Memphis aquifer wells

M404

Mean

Standard deviation about mean

M403, M416, M422, M424, M425

Mean

Standard deviation about mean
61

2.4

67

9.8
88

4

99

10

2.9

0.5

3.0

0.4

54

20

50

12

Affected Memphis aquifer wells

M401, M414, M415, M417, M418,

M419, M420, M421

Mean

Standard deviation about mean

50

191

191
54

5.0
2.6

120

116

40

36

1,150 

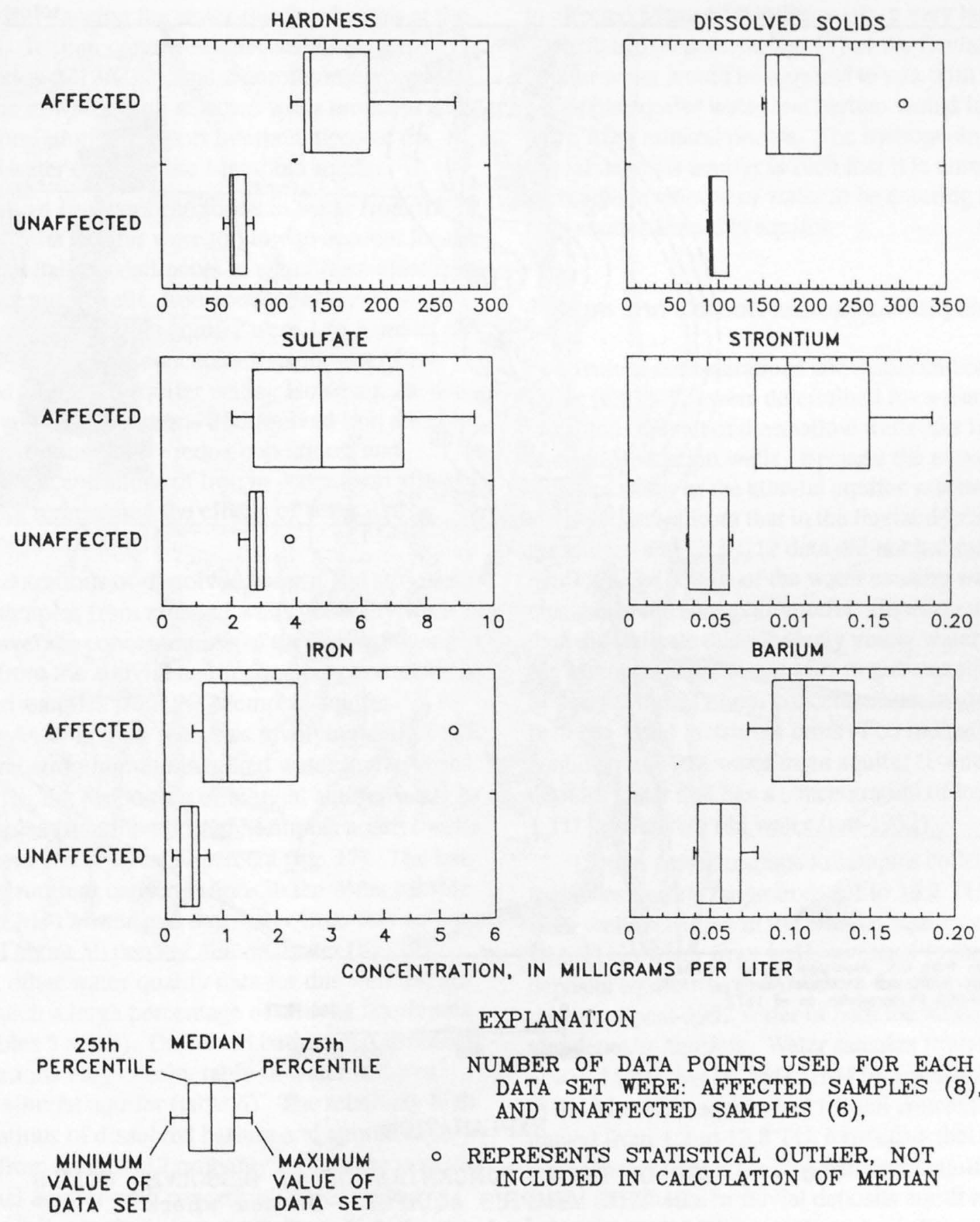

\section{EXPLANATION}

NUMBER OF DATA POINTS USED FOR EACH DATA SET WERE: AFFECTED SAMPLES (8), AND UNAFFECTED SAMPLES (6),

- REPRESENTS STATISTICAL OUTLIER, NOT INCLUDED IN CALCULATION OF MEDIAN

Figure 15. Selected water-quality properties and major inorganic and trace element constituent concentrations measured in samples affected and unaffected by water-quality changes in the Memphis aquifer at the Davis well field, Memphis, Tennessee, 1992. 


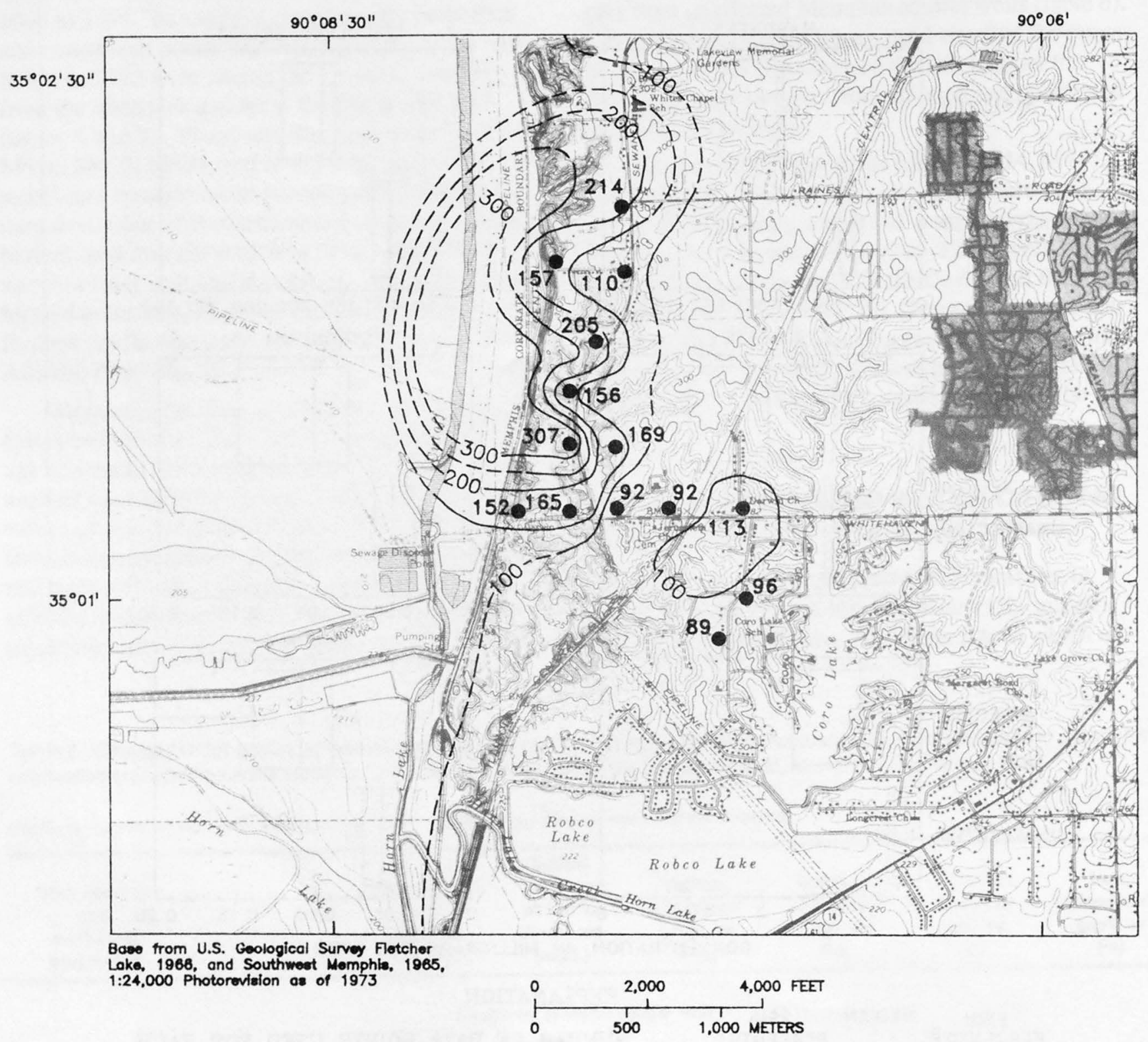

EXPLANATION

-100-- LINE OF EQUAL CONCENTRATION OF DISSOLVED SOLIDS

IN THE MEMPHIS AQUIFER--Dashed where

approximately located. Interval 50

milligrams per liter

WELL SCREENED IN MEMPHIS AQUIFER WHICH WAS

SAMPLED FOR WATER-QUALITY DATA

Figure 16. Dissolved solids concentrations in water from the Memphis aquifer in the Davis well field area, Memphis, Tennessee, 1992. 
the water-table aquifers is contributing water to the Memphis aquifer. However, differences in some trace element concentrations between the alluvial and fluvial deposits aquifers can be used to identify the source of ground water causing the water-quality changes at the well field. Tritium concentrations, stable carbonisotope ratios (C13/C12), and chlorofluorocarbon concentrations in water from selected wells provided additional information to support interpretations of the source of water entering the Memphis aquifer.

Dissolved iron concentrations in water from the fluvial deposits aquifer were too low to account for the increases in these constituents in water from affected Memphis aquifer wells. Iron concentrations in water from the fluvial deposits aquifer were 1 to 2 orders of magnitude lower than concentrations in water from unaffected Memphis aquifer wells. However, the distribution and concentrations of dissolved iron are controlled predominantly by redox conditions, and therefore, concentrations of iron in water from affected wells likely represented the effects of several processes, not just mixing.

Concentrations of dissolved barium and strontium in water samples from affected wells generally were between average concentrations of these constituents in samples from the alluvial aquifer and concentrations in unaffected samples from the Memphis aquifer

(fig. 17). Assuming no reactions involving dissolved barium and strontium in the mixed water in the Memphis aquifer, the proportion of alluvial aquifer water in most samples from the affected Memphis aquifer wells ranged from about 10 to 30 percent (fig. 17). The barium and strontium concentrations in the water sample from well M417 indicated that water from this well contained about 50 percent alluvial water (fig. 17); however, other water-quality data for this well did not indicate such a large percentage of alluvial aquifer water (tables 5 and 6). Dissolved barium and strontium concentrations vary considerably in water samples from the alluvial aquifer (table 6). The relatively high concentrations of dissolved barium and strontium in samples from well M417 probably result from water in the alluvial aquifer with concentrations of these constituents similar to those in water from well A2 (table 6) mixing with unaffected water in the Memphis aquifer in the same range of proportions as in water from the other affected wells.

Although barium and strontium can be reactive in dilute solutions, dissolved barium and strontium concentrations in water samples from the fluvial deposits aquifer were insufficient to account for the increases in these constituents in samples from the affected Memphis aquifer wells (fig. 17, table 6). In order to reach the measured concentrations of barium and strontium in affected Memphis aquifer wells, a very large proportion (50 to 100 percent, fig. 17) of the fluvial deposits aquifer water would be required to mix with unaffected Memphis aquifer water and barium would have to dissolve from mineral phases. The hydrogeology of the fluvial deposits aquifer is such that it is unrealistic for such a large amount of water to be entering the Memphis aquifer from this aquifer.

\section{Tritium and Carbon Isotopes Analysis}

Tritium concentrations and stable carbon-isotope ratios $(\mathrm{C} 13 / \mathrm{C} 12)$ were determined for water samples collected from all of the shallow wells and 10 Memphis aquifer production wells. Because the isotopic composition of water in the alluvial aquifer was not significantly different from that in the fluvial deposits aquifer, the tritium and $\mathrm{C} 13 / \mathrm{C} 12$ data did not indicate which aquifer is the source of the water causing water-quality changes in the Memphis aquifer. However, the isotopic data did indicate that relatively young water is entering the Memphis aquifer and affecting the quality of water in that aquifer. Tritium concentrations in ground water between 1 and 50 tritium units (TU) indicate a component of post-1952 water in an aquifer (Fontes, 1980). Ground water that has a concentration of less than $1 \mathrm{TU}$ is relatively old water (pre-1952).

Tritium concentrations in samples collected during this investigation range from 3.1 to $16.2 \mathrm{TU}$ in water from wells screened in the alluvial aquifer and 1.6 and 10.6 TU in water from wells screened in the fluvial deposits aquifer (table 7). These data indicate a component of post-1952 water in both the alluvial and fluvial deposits aquifers. Water samples from wells M401, M403, M414, M415, M419, and M421 screened in the Memphis aquifer had tritium concentrations that ranged from 1.2 to $13.8 \mathrm{TU}$, indicating that relatively young water has entered the Memphis aquifer from either the alluvial or fluvial deposits aquifers. Of these six wells, well M403 was the only well interpreted as unaffected based on the physical and chemical waterquality data. The tritium concentration of $1.2 \mathrm{TU}$ for well M403 indicates that any component of alluvial water in the sample from this well probably was small. Therefore, it is likely that leakage of water from the alluvial aquifer has not yet had an appreciable effect on 


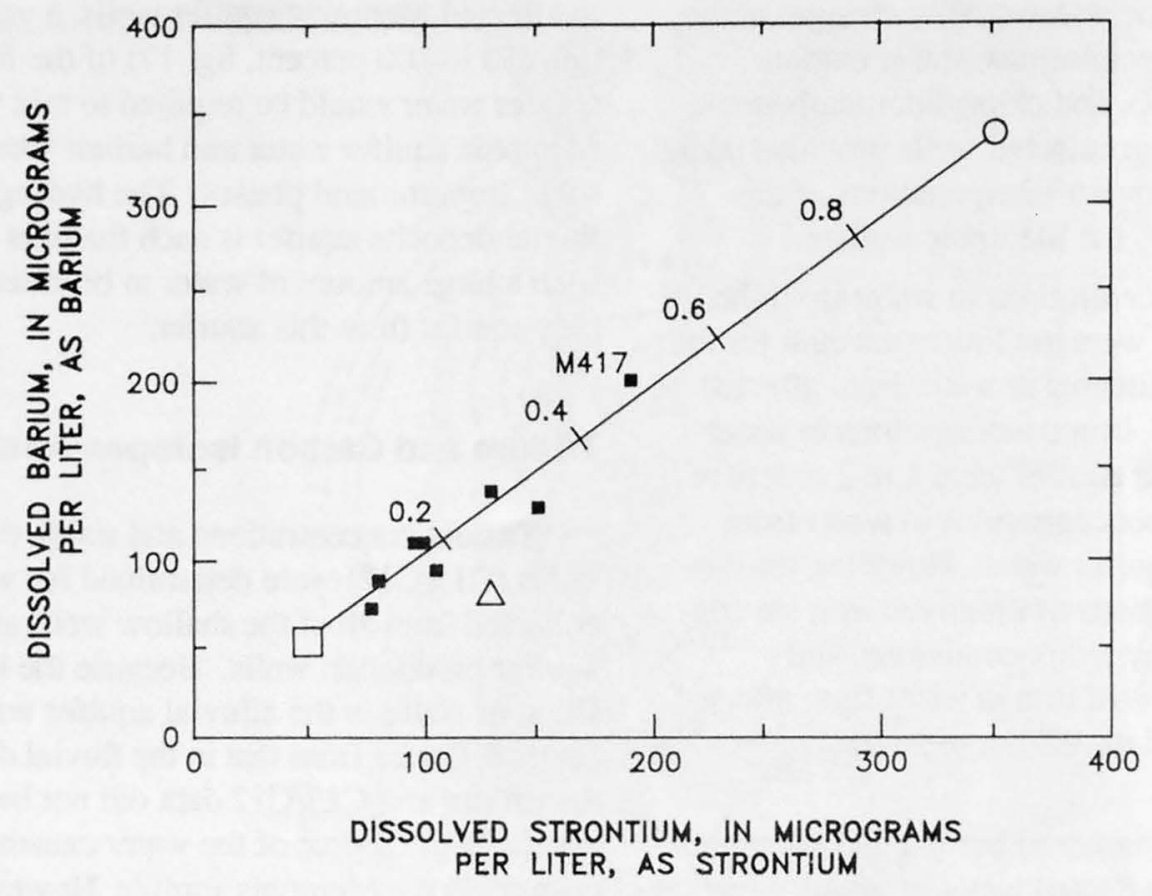

\section{EXPLANATION}

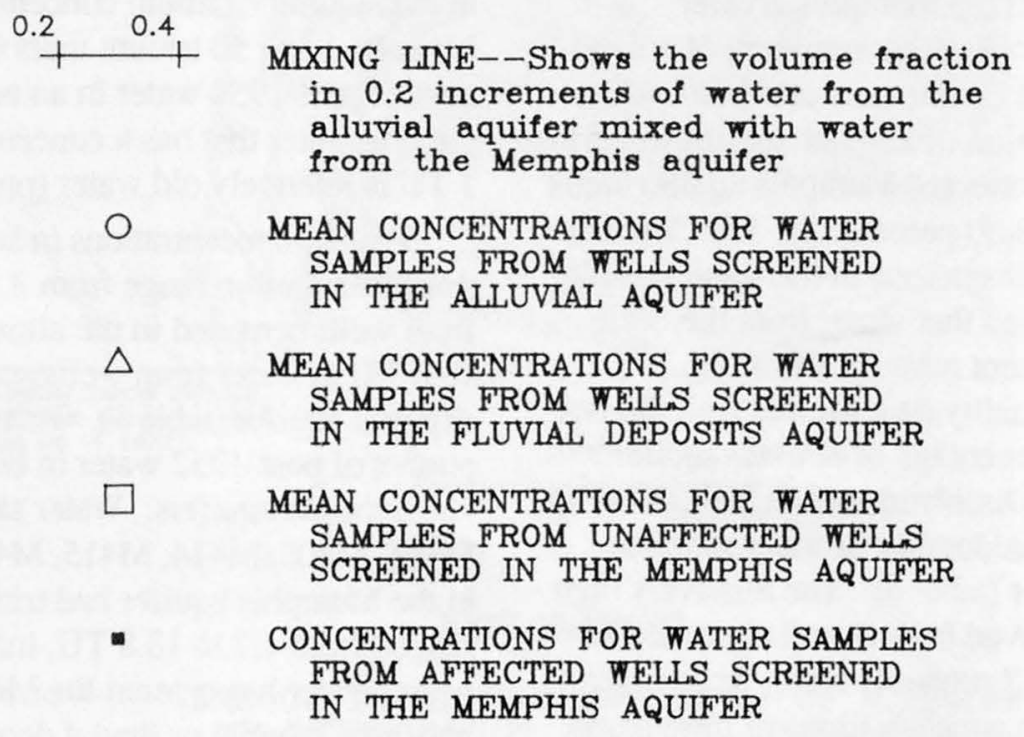

Figure 17. Dissolved barium and strontium concentrations analyzed in samples from wells screened in alluvial, fluvial deposits, and Memphis aquifers in the Davis well field area, Memphis, Tennessee, 1992. 
the concentrations of most constituents in the water from the Memphis aquifer near this well. Samples from production wells M404, M416, M424, and M425 screened in the Memphis aquifer (table 7), had tritium concentrations less than $1 \mathrm{TU}$, supporting the conclusion that these wells were unaffected by leakage of water from the alluvial or fluvial deposits aquifer.

Ratios of the stable isotopes of carbon (C13/C12) in water from both the alluvial and the fluvial deposits aquifers ranged from -11.3 to -15.4 per mil (table 7 ). Ratios measured in water samples from the Memphis aquifer ranged from -15.8 to -19.8 per mil. $\mathrm{C} 13 / \mathrm{C} 12$ values of -19 per mil or less in samples from Memphis aquifer wells M404, M416, M424, and M425 could represent water that had not been affected by leakage from either the alluvial or fluvial deposits aquifers, assuming that mixing is the primary process affecting C13/C12 ratios in the Memphis aquifer at the well field and that other sources of carbon do not significantly affect the isotopic composition of Memphis aquifer water. Such an interpretation is supported by data showing that water from these unaffected wells with C13/C12 values of -19 per mil

Table 7. Tritium concentrations and stable carbon-isotope ratios (C13/C12) in water from 22 wells screened in the alluvial, fluvial deposits, and Memphis aquifers in the Davis well field area, Memphis, Tennessee, 1992-93

[pCi/L, picocuries per liter; TU, tritium units; ${ }^{\circ}$, degrees; ', minutes; ", seconds; <, less than]

\begin{tabular}{|c|c|c|c|c|c|c|c|c|}
\hline \multicolumn{2}{|c|}{ Wellnumbers } & \multirow[b]{2}{*}{ Latitude } & \multirow[b]{2}{*}{ Longitude } & \multirow{2}{*}{$\begin{array}{l}\text { Altitude of } \\
\text { land surface } \\
\text { datum, In } \\
\text { feet above } \\
\text { sea level }\end{array}$} & \multirow{2}{*}{$\begin{array}{l}\text { Screened } \\
\text { interval, } \\
\text { In feet } \\
\text { below land } \\
\text { surface }\end{array}$} & \multirow[b]{2}{*}{$\begin{array}{c}\text { Date } \\
\text { sampled }\end{array}$} & \multirow{2}{*}{$\begin{array}{c}\text { Hydrogen } \\
\text { tritlum, } \mathrm{H}-3 \\
\text { cencentration } \\
\text { (pCVL) (TU) }\end{array}$} & \multirow{2}{*}{$\begin{array}{c}\text { Carbon, } \\
\text { C-13/C-12 } \\
\text { stable-isotope } \\
\text { ratio } \\
\text { (per mil) }\end{array}$} \\
\hline $\begin{array}{l}\text { Project } \\
\text { and } \\
\text { map }\end{array}$ & $\begin{array}{c}\text { USGS local } \\
\text { for } \\
\text { Tennessee }\end{array}$ & & & & & & & \\
\hline
\end{tabular}

\begin{tabular}{|c|c|c|c|c|c|c|c|c|c|}
\hline A1 & Sh:H-17 & $35^{\circ} 00^{\prime} 54^{\prime \prime}$ & $90^{\circ} 08^{\prime} 04^{\prime \prime}$ & 211 & $38-48$ & $09-17-92$ & 26 & 8.1 & -14.2 \\
\hline $\mathrm{A} 2$ & Sh:H-18 & $35^{\circ} 01^{\prime} 14^{\prime \prime}$ & $90^{\circ} 08^{\prime} 00^{\prime \prime}$ & 209 & $64-84$ & $09-17-92$ & 27 & 8.4 & -15.2 \\
\hline A3 & Sh:H-19 & $35^{\circ} 01^{\prime} 34^{\prime \prime}$ & $90^{\circ} 08^{\prime} 00^{\prime \prime}$ & 210 & $70-90$ & $09-16-92$ & 52 & 16.2 & -14.6 \\
\hline A4 & Sh:H-20 & $35^{\circ} 01^{\prime} 54^{\prime \prime}$ & $90^{\circ} 07^{\prime} 58^{\prime \prime}$ & 211 & $75-95$ & $09-16-92$ & 24 & 7.5 & -11.8 \\
\hline A5 & Sh:H-21 & $35^{\circ} 02^{\prime} 13^{\prime \prime}$ & $90^{\circ} 07^{\prime} 57^{\prime \prime}$ & 206 & $56-76$ & $09-15-92$ & 10 & 3.1 & -12.4 \\
\hline
\end{tabular}

Fluvial deposits aquifer

\begin{tabular}{|c|c|c|c|c|c|c|c|c|c|}
\hline F401 & Sh:J-189 & $35^{\circ} 01^{\prime} 25^{\prime \prime}$ & $90^{\circ} 07^{\prime} 29^{\prime \prime}$ & 290 & $72-82$ & $09-28-92$ & 29 & 9.1 & -14.6 \\
\hline F403 & Sh:J-188 & $35^{\circ} 01^{\prime} 15^{\prime \prime}$ & $90^{\circ} 07^{\prime} 29^{\prime \prime}$ & 257 & $58-68$ & $09-28-92$ & 27 & 8.4 & -11.3 \\
\hline F414 & Sh:J-191 & $35^{\circ} 02^{\prime} 07^{\prime \prime}$ & $90^{\circ} 07^{\prime} 27^{\prime \prime}$ & 295 & $74-84$ & $09-24-92$ & 13 & 4.1 & -14.4 \\
\hline F415 & Sh:H-23 & $35^{\circ} 01^{\prime} 57^{\prime \prime}$ & $90^{\circ} 07^{\prime} 42^{\prime \prime}$ & 305 & $79-89$ & $10-06-92$ & 20 & 6.2 & -15.1 \\
\hline F416 & Sh:J-190 & $35^{\circ} 01^{\prime} 56^{\prime \prime}$ & $90^{\circ} 07^{\prime} 26^{\prime \prime}$ & 295 & $75-85$ & $09-24-92$ & 34 & 10.6 & -15.4 \\
\hline F419 & Sh:H-22 & $35^{\circ} 01^{\prime} 26^{\prime \prime}$ & $90^{\circ} 0739^{\prime \prime}$ & 251 & $45-55$ & $09-24-92$ & 24 & 7.5 & -14.7 \\
\hline F421 & Sh:H-24 & $35^{\circ} 01^{\prime} 15^{\prime \prime}$ & $90^{\circ} 070^{\prime \prime}$ & 254 & $35-45$ & $10-15-92$ & 5 & 1.6 & -14.7 \\
\hline \multicolumn{10}{|c|}{ Memphis aquifer } \\
\hline M401 & Sh:J-143 & $35^{\circ} 01^{\prime} 25^{\prime \prime}$ & $90^{\circ} 07^{\prime} 29^{\prime \prime}$ & 291 & $370-450$ & $10-01-92$ & 6 & 1.9 & -17.7 \\
\hline M403 & Sh:H-10 & $35^{\circ} 01^{\prime} 15^{\prime \prime}$ & $90^{\circ} 07^{\prime} 29^{\prime \prime}$ & 258 & $368-448$ & 09-30-92 & 4 & 1.2 & -18.4 \\
\hline M404 & Sh:J-146 & $35^{\circ} 01^{\prime} 14^{\prime \prime}$ & $90^{\circ} 07^{\prime} 17^{\prime \prime}$ & 247 & $360-440$ & 04-01-93 & $<1$ & $<1$ & -19.4 \\
\hline M414 & Sh:J-145 & $35^{\circ} 02^{\prime} 07^{\prime \prime}$ & $90^{\circ} 07 ' 27^{\prime \prime}$ & 295 & $385-465$ & $10-02-92$ & 11 & 3.4 & -16.9 \\
\hline M415 & Sh:H-8 & $35^{\circ} 01^{\prime} 57^{\prime \prime}$ & $90^{\circ} 07^{\prime} 42^{\prime \prime}$ & 304 & $536-616$ & $10-01-92$ & 10 & 3.1 & -17.6 \\
\hline M416 & Sh:J-137 & $35^{\circ} 01^{\prime} 56^{\prime \prime}$ & $90^{\circ} 07^{\prime} 26^{\prime \prime}$ & 295 & $415-495$ & $10-08-92$ & $<1$ & $<1$ & -19.5 \\
\hline M419 & Sh:H-5 & $35^{\circ} 01^{\prime} 26^{\prime \prime}$ & $90^{\circ} 07^{\prime} 39^{\prime \prime}$ & 251 & $331-411$ & $10-02-92$ & 44 & 13.8 & -15.8 \\
\hline M421 & Sh:H-9 & $35^{\circ} 01^{\prime} 14^{\prime \prime}$ & $90^{\circ} 07^{\prime} 50^{\prime \prime}$ & 243 & $360-440$ & $10-07-92$ & 28 & 8.8 & -16.2 \\
\hline M424 & Sh:J-139 & $35^{\circ} 01^{\prime} 00^{\prime \prime}$ & $90^{\circ} 07^{\prime} 03^{\prime \prime}$ & 292 & $380-460$ & 04-01-93 & $<1$ & $<1$ & -19.0 \\
\hline M425 & Sh:J-144 & $35^{\circ} 00^{\prime} 52^{\prime \prime}$ & $90^{\circ} 07^{\prime} 08^{\prime \prime}$ & 284 & $370-450$ & $04-01-93$ & $<1$ & $<1$ & -19.8 \\
\hline
\end{tabular}


or less had tritium concentrations of less than $1 \mathrm{TU}$ (table 7) and that other water-quality properties and constituent concentrations had not increased over time (table 3 and Appendix 2). Values greater than -19 per mil could indicate water that has resulted from mixing of isotopically "heavier" water from the alluvial or fluvial deposits aquifers with unaffected water in the Memphis aquifer. Because $\mathrm{C} 13 / \mathrm{C} 12$ values in water samples from the alluvial and fluvial deposits were similar, identification of which of these aquifers is contributing water to the Memphis aquifer is impossible using carbon-isotope values.

\section{Chlorofluorocarbon Analysis}

Chlorofluorocarbons (CFC's) are stable man-made volatile organic compounds that have been used since the 1930's as refrigerants, aerosol propellants, blowing agents in foam rubber and plastic production, and solvents. Atmospheric concentrations of CFC's have steadily increased since their initial production. CFC concentrations have been measured in the atmosphere since the mid-1970's and, prior to that, concentrations were estimated from production data (Busenberg and Plummer, 1992). These data and the aqueous solubility of CFC's form the basis for the use of CFC's as hydrologic tracers and age-dating tools (Busenberg and Plummer, 1992).

For this investigation, CFC's were used as tracers to indicate the presence or absence of post-1940 water in the aquifers in the Davis well field area (table 8).

Recharge dates given in table 8 were calculated assuming a recharge water temperature of $12{ }^{\circ} \mathrm{C}$ and no modification of CFC concentrations by biological, geochemical, or hydrological processes. These dates are given only to indicate the presence of young (post1945, CFC-11 or post-1940, CFC-12) water in the wells sampled.

Water samples were collected from one well screened in the alluvial aquifer and one well screened in the fluvial deposits aquifer for CFC analysis. CFC concentrations measured in samples from well A3 screened in the alluvial aquifer indicated post- 1945 recharge to the aquifer (table 8 ). Samples from well F419 screened in the fluvial deposits aquifer contained CFC concentrations in excess of air-water equilibrium concentrations, indicating post-1940 recharge from a source contaminated with CFC's (Niel Plummer, U.S. Geological Survey, written commun., 1993). Results from these analyses support conclusions based on the tritium data for water from the alluvial and fluvial deposits aquifers (table 7), in that the CFC data indicate the presence of relatively young water in these aquifers.

Water samples were collected from four production wells screened in the Memphis aquifer for CFC analysis (table 8). Major and trace inorganic constituents in water from wells M414 and M419 were interpreted as having been affected by leakage of water from another aquifer, and these constituents in water from wells M404 and M416 were interpreted as not affected (tables 4 and 5). Analyses of water samples from wells M404 and M416 contained no measurable concentrations of CFC's (table 8) indicating no post-1940 water in these wells, which is consistent with conclusions based on the tritium data (table 7).

Although tritium data for wells M414 and M419 indicated a component of relatively young water in samples from these wells, samples from well M419 contained no measurable concentrations of CFC's (table 8), and samples from well M414 contained measurable concentrations of CFC-12 only. Environmental factors could account for the absence of both CFC's in water from well M419 and CFC-11 in well M414. CFC's are susceptible to degradation in certain subsurface environments. Microbial degradation of both CFC-11 and CFC-12 has been documented in anaerobic methanogenic soils and sediments, but no degradation has been observed in aerobic aquifer systems (Lovely and Woodward, 1992). The rate of microbial degradation of CFC's has been shown to decrease with increasing fluorine content (Busenberg and Plummer, 1992); therefore, $\mathrm{CFC}-11\left(\mathrm{CCl}_{3} \mathrm{~F}\right)$ would be degraded more rapidly than $\mathrm{CFC}-12\left(\mathrm{CCl}_{2} \mathrm{~F}_{2}\right)$. $\mathrm{CFC}$ analyses of samples from well M414 could indicate degradation of CFC-11 and persistence of CFC-12, and data from well M419 could indicate degradation of both CFC's in an anaerobic aquifer. A methane concentration of $1.3 \mathrm{mg} / \mathrm{L}$ analyzed in a water sample from well M419 was above concentrations expected from normal atmospheric recharge, indicating that methanogenesis is occurring in the Memphis aquifer (Ray Van Hoven, U.S. Geological Survey, written commun., 1994). CFC's in samples from well M414 confirm the presence of young water in the Memphis aquifer, as indicated by tritium data (table 7).

CFC data indicate that it is unlikely that the fluvial deposits aquifer is the source of water causing waterquality changes in the Memphis aquifer. Concentrations of both CFC's measured in water from the fluvial 
deposits aquifer are high relative to concentrations in water from the alluvial and Memphis aquifers (table 8). If leakage from the fluvial deposits aquifer to the Memphis aquifer was occurring, the resultant mix of water probably would contain CFC-11 and CFC-12 as a result of the large concentrations of both of these CFC's in water from the fluvial deposits aquifer.

CFC concentrations in water samples from affected Memphis aquifer wells are more likely the result of water from this aquifer mixing with water from the alluvial aquifer than with water from the fluvial deposits aquifer. CFC concentrations in water samples from the alluvial aquifer are two to three orders of magnitude lower than those measured in the fluvial deposits aquifer (table 8). Although the concentration of CFC-12 in water samples from well M414 is greater than that measured in water from alluvial aquifer well A3 (table 8), CFC concentrations in the alluvial aquifer may vary spatially such that ground water with higher CFC concentrations than those measured in well A3 may be moving to the area of well M414. Variations in $\mathrm{CFC}$ concentrations in water from the alluvial aquifer could result from microbial degradation of CFC's,

Table 8. Chlorofluorocarbon concentrations in water from six wells screened in the alluvial, fluvial deposits, and Memphis aquifers in the Davis well field area, Memphis, Tennessee, 1993

[pg/kg, picograms per kilogram; chlorofluorocarbon (CFC) date for CFC-11 of $<1945$ means older than 1945 and date for CFC-12 of $<1940$ means older than 1940; contam. (contaminated) means that CFC concentrations were in excess of present atmospheric air-water equilibrium; dates were calculated using a recharge temperature of $12^{\circ} \mathrm{C}$ and an atmospheric pressure of 760 millimeters]

\begin{tabular}{|c|c|c|c|c|c|c|c|}
\hline $\begin{array}{l}\frac{\text { Well }}{\text { Project }} \\
\text { and } \\
\text { map }\end{array}$ & $\begin{array}{l}\text { numbers } \\
\text { USGS local } \\
\text { for } \\
\text { Tennessee }\end{array}$ & $\begin{array}{c}\text { Date } \\
\text { sampled }\end{array}$ & $\begin{array}{c}\text { Time } \\
\text { sampled }\end{array}$ & $\begin{array}{c}\text { Chloro- } \\
\text { fluoro- } \\
\text { carbon } \\
11 \\
(\mathbf{p g} / \mathrm{kg})\end{array}$ & $\begin{array}{c}\text { Chloro- } \\
\text { fluoro- } \\
\text { carbon } \\
12 \\
(\mathrm{pg} / \mathrm{kg})\end{array}$ & $\begin{array}{l}\text { Model } \\
\text { chloro- } \\
\text { fluoro- } \\
\text { carbon } 11 \\
\text { recharge } \\
\text { date }\end{array}$ & $\begin{array}{l}\text { Model } \\
\text { chloro- } \\
\text { fluoro- } \\
\text { carbon } 12 \\
\text { recharge } \\
\text { date }\end{array}$ \\
\hline \multicolumn{8}{|c|}{ Alluvial aquifer } \\
\hline A3 & Sh:H-19 & $04-15-93$ & $\begin{array}{l}1040 \\
1100 \\
1120\end{array}$ & $\begin{array}{l}0.3 \\
2.6 \\
2.3\end{array}$ & $\begin{array}{r}10.5 \\
8.5 \\
7.5\end{array}$ & $\begin{array}{l}1947 \\
1951 \\
1951\end{array}$ & $\begin{array}{l}1955 \\
1954 \\
1953\end{array}$ \\
\hline \multicolumn{8}{|c|}{ Fluvial deposits aquifer } \\
\hline F419 & Sh:H-22 & $04-15-93$ & $\begin{array}{l}1400 \\
1435 \\
1450\end{array}$ & $\begin{array}{l}1,463.6 \\
1,267.8 \\
1,209.6\end{array}$ & $\begin{array}{l}1,248.7 \\
1,620.1 \\
1,742.3\end{array}$ & $\begin{array}{l}\text { contam. } \\
\text { contam. } \\
\text { contam. }\end{array}$ & $\begin{array}{l}\text { contam. } \\
\text { contam. } \\
\text { contam. }\end{array}$ \\
\hline \multicolumn{8}{|c|}{ Memphis aquifer } \\
\hline M404 & Sh:J-146 & $04-16-93$ & $\begin{array}{l}1030 \\
1040 \\
1110\end{array}$ & $\begin{array}{r}0.0 \\
.0 \\
.0\end{array}$ & $\begin{array}{r}0.0 \\
.0 \\
.0\end{array}$ & $\begin{array}{l}<1945 \\
<1945 \\
<1945\end{array}$ & $\begin{array}{l}<1940 \\
<1940 \\
<1940\end{array}$ \\
\hline M414 & Sh:J-145 & $04-16-93$ & $\begin{array}{l}840 \\
905 \\
920\end{array}$ & $\begin{array}{l}.0 \\
.0 \\
.0\end{array}$ & $\begin{array}{l}126.6 \\
122.2 \\
120.8\end{array}$ & $\begin{array}{l}<1945 \\
<1945 \\
<1945\end{array}$ & $\begin{array}{l}1974 \\
1974 \\
1974\end{array}$ \\
\hline M416 & Sh:J-137 & $04-15-93$ & $\begin{array}{l}1805 \\
1835 \\
1850\end{array}$ & $\begin{array}{l}.0 \\
.0 \\
.0\end{array}$ & $\begin{array}{l}.0 \\
.0 \\
.0\end{array}$ & $\begin{array}{l}<1945 \\
<1945 \\
<1945\end{array}$ & $\begin{array}{l}<1940 \\
<1940 \\
<1940\end{array}$ \\
\hline M419 & Sh:H-5 & $04-15-93$ & $\begin{array}{l}1605 \\
1625 \\
1640\end{array}$ & $\begin{array}{l}.0 \\
.0 \\
.0\end{array}$ & $\begin{array}{l}.0 \\
.0 \\
.0\end{array}$ & $\begin{array}{l}<1945 \\
<1945 \\
<1945\end{array}$ & $\begin{array}{l}<1940 \\
<1940 \\
<1940\end{array}$ \\
\hline
\end{tabular}


variable unsaturated zone thicknesses or permeabilities (through which recharge moves), or sorption of CFC's onto organic material within the aquifer.

Interpretation of the limited CFC data collected at the Davis well field is somewhat problematic. However, these data confirm the presence of relatively young water in the Memphis aquifer and, combined with other water-quality and isotope data, indicate that the source of the ground water causing water-quality changes at the Davis well field is leakage from the alluvial aquifer.

\section{NETPATH Geochemical-Model Analysis}

NETPATH geochemical model code (modeling NET geochemical reactions along a flow $\underline{\text { PATH}}$ ) can be applied two ways. One application is to model massbalance geochemical reactions along a flow path, in which dissolved constituents are measured in groundwater samples at the beginning and end of the flow path. Another application is as a mixing model, in which percentages of two initial (source) waters and a final water representing a possible mixture of these source waters are specified (Plummer and others, 1991).

NETPATH can be used in two ways to calculate the percentage of initial waters that combine to form a final water. Percentages can be calculated from changes in the concentration of a conservative tracer (such as dissolved chloride) that occur during mixing. Percentages also can be calculated from changes in the concentrations of several dissolved major inorganic and trace element constituents that define the dominant geochemical reactions that occur during mixing.

NETPATH was used during this investigation to calculate the percentage of water from an alluvial aquifer well mixed with water from an unaffected Memphis aquifer well to approximate the composition of water from two affected Memphis aquifer wells. Water-quality data from individual wells were used rather than mean concentration values calculated from multiple wells because mean concentration values can obscure the effects of mixing. However, constituent concentrations in waters from the individual wells are representative of the alluvial aquifer, and unaffected and affected Memphis aquifer samples (table 9).

To approximate redox conditions in ground water at the beginning of the flow path for use in the NETPATH geochemical analysis, dissolved oxygen (DO) and hydrogen sulfide concentrations were measured in water samples from several wells screened in the alluvial and Memphis aquifers (table 9). Dissolved-oxygen concentrations were measured in the field using a calibrated DO meter. Hydrogen sulfide concentrations were measured in the field using a portable colorimeter. Methane concentrations were measured at a USGS National Research Program laboratory. Calcium, sulfate, chloride, and iron concentrations listed in table 10 were measured at the USGS National Water Quality Laboratory (tables 4 and 5).

In the first set of models, dissolved chloride was used as a conservative tracer to calculate mixing percentages in NETPATH. Water-quality data measured in samples from wells A3 (alluvial aquifer) and M404 (unaffected Memphis aquifer) were input to represent the composition of the two initial (source) waters at the beginning of the flow path (tables 4 and 5). Waterquality data in samples from wells M419 or M421 (affected Memphis aquifer) were input to represent the composition of water at the end of the flow path. Major inorganic constituent and trace element concentrations were greater in water samples from M419 compared to M421 (tables 4 and 5); therefore, water from M419 probably contained a larger percentage of alluvial aquifer.

The mixing models using dissolved chloride as a conservative tracer indicated that water from M419 was a mixture of 3 percent alluvial aquifer water and 97 percent unaffected Memphis aquifer water (table 10). Similarly, water from M421 was a mixture of less than 1 percent alluvial aquifer water and greater than 99 percent unaffected Memphis aquifer water.

Dissolved chloride is considered a conservative tracer. As an anion, its concentration is not reduced significantly by adsorption onto sediments as water moves along the flow path. The mean dissolvedchloride concentration value from alluvial aquifer water samples was higher than that of the Memphis aquifer water samples (table 9). However, there was no statistically significant difference in mean dissolvedchloride concentration when water-quality data collected during 1992 from affected and unaffected Memphis aquifer samples were compared (table 9; statistical significance is indicated by non-overlapping standard deviations about mean concentration values). Because all Memphis aquifer water samples showed similar dissolved-chloride concentrations (table 4), dissolvedchloride, when used as a conservative tracer, underestimated the percentage of alluvial aquifer water. 
Table 9. Selected major inorganic and trace element constituent concentrations used for NETPATH geochemical analysis at the Davis well field, Memphis, Tennessee

[mg/L, milligrams per liter, $\mu \mathrm{g} / \mathrm{L}$, micrograms per liter, values given as < (less than) indicate that the concentration was below the level of detection for the analytical method used and do not indicate the presence or absence of a constituent; --, indicates that mean values were not calculated because concentrations of dissolved oxygen, hydrogen sulfide, and methane were not measured for all wells]

\begin{tabular}{|c|c|c|c|c|c|c|c|}
\hline $\begin{array}{l}\text { Well number } \\
\text { and } \\
\text { statistical } \\
\text { parameter }\end{array}$ & $\begin{array}{l}\text { Calclum, } \\
\text { dlssolved } \\
\text { (mg/l as } \\
\text { Ca) }\end{array}$ & $\begin{array}{l}\text { Sulfate, } \\
\text { dissolved } \\
\text { (mg/l as } \\
\left.\mathrm{SO}_{4}\right)\end{array}$ & $\begin{array}{l}\text { Oxygen, } \\
\text { dissolved } \\
\text { (mg/l as } \\
\mathrm{O}_{2} \text { ) }\end{array}$ & $\begin{array}{l}\text { Hydrogen } \\
\text { sulfide, } \\
\text { dlissolved } \\
\text { (mg/l as } \\
\left.\mathrm{H}_{2} \mathrm{~S}\right)\end{array}$ & $\begin{array}{l}\text { Chloride, } \\
\text { dlsesolved } \\
\text { (mg/l as } \\
\text { Cl) }\end{array}$ & $\begin{array}{l}\text { Methane, } \\
\text { dlssolved } \\
\text { (mg/l as } \\
\left.\mathrm{CH}_{4}\right)\end{array}$ & $\begin{array}{c}\text { Iron, } \\
\text { dlesolved } \\
(\mu \mathrm{g} / \mathrm{L} \text { as } \\
\left.\mathrm{Fe}_{\theta}\right)\end{array}$ \\
\hline
\end{tabular}

Alluvial aquifer

$\begin{array}{lccccccc}\text { Well A3 } & 110 & 1.8 & <0.1 & 0.04 & 10 & 2.53 & 4,400 \\ \text { All alluvial aquifer wells } & & & & & & & \\ \quad \text { Mean } & 96 & 12 & -- & -- & 7.8 & -- & 4,880 \\ \quad \text { Standard deviation } & 13 & 17 & -- & -- & 2.3 & -- & 2,490\end{array}$

Unaffected Memphis aquifer

Well M404

All unaffected Memphis aquifer wells Mean

Standard deviation
14

15 1.9
3.0

2.9

0.5

Affected Memphis aquifer
Well M419

Well M421

All affected Memphis aquifer wells Mean affected wells

Standard deviation
58

28

36

10
7.3

4.5

5.0

2.6

$$
\begin{array}{r}
<.1 \\
.1
\end{array}
$$

$-$

$-$
$<.01$

$-$

$-$

.07

4.0

3.6

0.6
.006

$-$

$-$
295

251

296
In the second set of NETPATH models, no conservative tracer was used (table 11). Instead, mixing percentages were based on reactions of major inorganic constituents, trace elements, and dissolved gases during mixing of initial waters A3 (alluvial aquifer) and M404 (unaffected Memphis aquifer). Ground-water composition at the end of the flow path was represented again by affected Memphis aquifer samples from M419 or M421.

NETPATH models in table 11 show mixing percentages based on major inorganic constituent, trace element, and dissolved gas concentrations in the ground-water samples. These models suggest that water from M419 was a mixture of 18 percent alluvial aquifer water (from well A3) and 82 percent unaffected Memphis aquifer water (from well M404). The model predicts a dissolved methane concentration of $33.4 \mathrm{mg} / \mathrm{L}$ in the final water, which exceeds the measured concentration of $1.30 \mathrm{mg} / \mathrm{L}$ (table 9 ).
Similarly, model simulations suggest that the water from M421 was a mixture of 1 percent alluvial aquifer water (from well A3) and 99 percent unaffected Memphis aquifer water (from well M404). The model predicts a dissolved methane concentration of $16.5 \mathrm{mg} / \mathrm{L}$ in the final water, which exceeds the measured concentration of $0.173 \mathrm{mg} / \mathrm{L}$ (table 9).

Differences in concentrations of dissolved methane measured and those calculated in the model likely are the result of methane loss from degassing of the water as the wells were pumped. Or, the NETPATH models overestimated methane concentrations because additional geochemical and mineralogic data were needed to further constrain the models.

Dominant geochemical reactions inferred along the flow path were dissolution of mineral phases, ion exchange of calcium and magnesium for sodium in clay minerals, and methanogenesis (bacteria-mediated anaerobic degradation of organic matter to form 
Table 10. NETPATH geochemical model constraints and phases used to simulate mixing of alluvial aquifer water (well A3) with unaffected Memphis aquifer water (well M404) to obtain affected Memphis aquifer water (wells M419 and M421), using dissolved chloride as a conservative tracer to determine mixing percentages

[Phases that are forced to dissolve or enter solution are designated as + . Phases that are forced to precipitate or leave solution are designated as -. Positive values for the exchange phase indicate that calcium and magnesium are adsorbed or lost from solution, and sodium is desorbed or enters solution. " $\mathrm{CH}_{2} \mathrm{O}^{\prime}$ phase represents organic matter]

\section{Model Input}

Initial Well 1: A3 Initial Well 2: M404

Final Well: M419 or M421

Constraints: 8

carbon calcium

sulfur magnesium

sodium iron

redox chloride
Phases: 7

" $\mathrm{CH}_{2} \mathrm{O}$ " calcite methane- dolomite pyrite goethite

Mixing percentages determined by chloride

\section{Model Output}

Final Well M419

Percent A3 water

3

Final Well M421

\section{Percent A3 water}

less than 1
Percent M404
water

97
Reactions along the flow path

Organic matter oxidizes, methane evolves; calcite, dolomite, pyrite, and goethite dissolve; calcium or magnesium are adsorbed, sodium is desorbed from sediments

Reactions along the flow path

Organic matter oxidizes, methane evolves; calcite, dolomite, pyrite, and goethite dissolve; calcium or magnesium are adsorbed, sodium is desorbed from sediments dissolved methane and carbon dioxide). These models were constrained by measurements of dissolved methane in alluvial aquifer and Memphis aquifer samples (table 9). Methane most likely is generated in both aquifers; however, dissolved methane concentrations were higher in water samples from the alluvial aquifer and affected Memphis aquifer wells than in the unaffected Memphis aquifer (table 9). It is likely that dissolved methane travels with alluvial aquifer water into the Memphis aquifer.

In all models, calcite and dolomite were undersaturated or near equilibrium in ground water from the alluvial and Memphis aquifers. Under equilibrium conditions, pyrite, goethite, and other iron mineral phases will precipitate in the alluvial and Memphis aqui- fers. Iron mineral phases have been observed in clay, silt, and sand in the alluvial aquifer in the Memphis area (Parks and Mirecki, 1992). Iron minerāl phases generally have not been observed in well cuttings of sand and clay in the Memphis aquifer. Because iron oxide and sulfide mineral phases have not been observed as precipitates in the Memphis aquifer, models that resulted in the precipitation of these mineral phases were not considered realistic.

Redox conditions along the flow path were difficult to assess, particularly for iron and sulfur species. Iron oxide and sulfide mineralogic data from subsurface aquifer materials, and dissolved ferric $\left(\mathrm{Fe}^{3+}\right)$ and ferrous $\left(\mathrm{Fe}^{2+}\right)$ iron concentrations in the ground-water samples were not determined. However, the redox 
Table 11. NETPATH geochemical model constraints and phases used to simulate mixing of alluvial aquifer water (well $A 3$ ) with unaffected Memphis aquifer water (well M404) to obtain affected Memphis aquifer water (wells M419 and M421), using selected major inorganic and trace element constituents to determine mixing percentages

[Phases that are forced to dissolve or enter solution are designated as + . Phases that are forced to precipitate or leave solution are designated as -- Positive values for the exchange phase indicate that calcium and magnesium are adsorbed or lost from solution, and sodium is desorbed or enters solution. " $\mathrm{CH}_{2} \mathrm{O}$ " phase represents organic matter]

Model Input

Initial Well 1: A3 Initial Well 2: M404

Final Well: M419 or M421

Constraints: 7

carbon

sulfur

sodium

redox
Phases: 7

" $\mathrm{CH}_{2} \mathrm{O}$ "+ calcite

methane- dolomite

pyrite goethite dolomite

Model Output

Final Well M419

Percent A3

water

18

Percent M404

water

82

Percent M404

water

98

Final Well M421
Percent A3

water

2

Reactions along the flow path

Organic matter oxidizes, methane evolves (final concentration $33.4 \mathrm{mg} / \mathrm{L}$ dissolved methane); dolomite, pyrite, and goethite dissolve; calcium or magnesium are adsorbed, sodium is desorbed from sediments

Reactions along the flow path

Organic matter oxidizes, methane evolves (final concentration $16.5 \mathrm{mg} / \mathrm{L}$ dissolved methane); calcite, dolomite, and pyrite dissolve; calcium or magnesium are adsorbed, sodium is desorbed from sediments potential (Eh) was calculated in NETPATH using dissolved sulfate $\left(\mathrm{SO}_{4^{-}}\right.$; table 4$)$ and hydrogen sulfide $\left(\mathrm{H}_{2} \mathrm{~S}\right.$; table 9) concentrations measured in water samples from A3, M404, M419, and M421. Calculated Eh values ranged between -0.19 and 0 millivolts. Subsequently, goethite $(\mathrm{FeO}(\mathrm{OH}))$ and pyrite $\left(\mathrm{FeS}_{2}\right)$ were inferred as likely iron mineral phases.

\section{SUMMARY AND CONCLUSIONS}

An investigation was conducted at the Memphis Light, Gas and Water Division (MLGW) Davis well field to collect and interpret hydrogeologic and waterquality data to determine the source of ground water causing water-quality changes in the Memphis aquifer. Since 1972, MLGW periodically has collected and analyzed water samples from most of the 14 wells in this well field for hardness and alkalinity and concentrations of sulfate, chloride, and iron. Results of these analyses indicated that physical properties and chemical constituent concentrations in water from several wells increased over time. For example, water from 8 of the 14 production wells sampled in 1991 had hardness values from 29 to 224 percent greater than those in samples collected in 1972.

During this investigation, 12 shallow wells were installed in the alluvial and fluvial deposits aquifers, which overlie the upper confining unit of the Memphis aquifer in the Davis well field area. A test hole drilled for one of five wells installed in the alluvial aquifer indicated that the confining unit locally is absent beneath the Mississippi Alluvial Plain. Water-level data indicated a hydraulic head difference between the alluvial aquifer and the Memphis aquifer of about 10 feet. The local absence 
of the confining unit and the 10-foot head difference indicate a potential for downward leakage of ground water from the alluvial aquifer to the Memphis aquifer.

Alkalinity and hardness and concentrations of dissolved iron and barium in water samples from the alluvial, fluvial deposits, and Memphis aquifers indicated substantial differences in the quality of water from these aquifers. Median values for alkalinity and hardness and concentrations of dissolved strontium and barium were highest in water samples from the alluvial aquifer and lowest in samples from the Memphis aquifer. Median values of dissolved iron concentrations were highest in water samples from the alluvial aquifer and lowest in samples from the fluvial deposits aquifer.

For this investigation, water samples from production wells screened in the Memphis aquifer were interpreted as affected or unaffected by leakage of more highly mineralized water into the Memphis aquifer from another aquifer on the basis of changes in water quality over time. Water samples from affected wells had greater values for most water-quality properties and constituent concentrations than those from unaffected wells. In general, unaffected wells are located in the eastern part of the Davis well field away from the Mississippi Alluvial Plain and affected wells are located in the western part of the Davis well field near the Mississippi Alluvial Plain. Concentrations of dissolved solids in water samples from wells screened in the Memphis aquifer increased from east to west, indicating that the source of water entering the Memphis aquifer was west of the well field.

Most major inorganic constituent concentrations did not differ significantly between water samples from the alluvial and fluvial deposits aquifers, so the source of water contributing to the Memphis aquifer could not be identified using these constituents. However, significant differences in some trace-element concentrations in water from the alluvial and fluvial deposits aquifers indicated that the alluvial aquifer was the source of water causing water-quality changes at the well field. Dissolved barium, strontium, and iron concentrations measured in water samples from the fluvial deposits aquifer were too low to account for the increases in the concentration of these constituents in samples from the affected Memphis aquifer wells.

Tritium analyses of water samples from the alluvial and fluvial deposits aquifers indicated that a component of post-1952 water was present in both aquifers. Tritium analyses of water samples from the Memphis aquifer indicated that production wells inter- preted as affected by leakage of water from another aquifer contained a component of relatively young water, and with one exception those interpreted as unaffected did not. Water samples from one Memphis aquifer well that had been interpreted as unaffected by leakage of water from another aquifer on the basis of major inorganic and trace-element concentrations contained a small amount of tritium, indicating that a small component of relatively young water had entered the Memphis aquifer near this well.

Concentrations of chlorofluorocarbons (CFC's) in ground water were used in an attempt to determine the presence or absence of post-1940 and post-1945 recharge water in the Memphis aquifer. This approach was not totally successful because CFC's were absent in most water samples from two wells interpreted as affected by leakage from another aquifer. The absence of CFC's from the affected Memphis aquifer wells probably is the result of microbial degradation of CFC's in an anaerobic aquifer. The presence of CFC-12 in water from one of the affected wells sampled, indicated that a component of post-1940 water was present in the Memphis aquifer at this well.

Water-quality data collected for this investigation were used in the geochemical model code NETPATH to estimate the percentage of alluvial aquifer water entering the Memphis aquifer and causing water-quality changes. Percentages of mixed waters were calculated two ways. First, dissolved chloride was used as a conservative tracer to calculate mixing percentages. Second, changes in the concentration of selected dissolved major inorganic and trace-element constituents were used. Reactions that might occur when alluvial aquifer and unaffected Memphis aquifer waters are mixed include dissolution of mineral phases, ion exchange on clay mineral surfaces, and methanogenesis.

Chloride used as a conservative tracer in NETPATH indicated that a mixture of 3 percent alluvial and 97 percent unaffected Memphis aquifer water would produce the chloride concentration measured in water from the Memphis aquifer well most affected by waterquality changes. The small percentage of alluvial aquifer water mixed with unaffected Memphis aquifer water to produce affected Memphis aquifer water were the result of the small differences in concentrations of dissolved chloride in waters from the unaffected and affected Memphis aquifer wells used in this model.

Changes in selected dissolved major inorganic and trace-element constituent concentrations used in NETPATH indicated that a mixture containing 18 percent 
alluvial aquifer water and 82 percent Memphis aquifer water would produce measured concentrations in water from the Memphis aquifer well most affected by waterquality changes. However, this model predicted higher dissolved methane concentrations than were measured in samples from affected Memphis aquifer wells.

\section{SELECTED REFERENCES}

Busenberg, Eurybiades, and Plummer, L.N., 1992, Use of chlorofluorocarbons $\left(\mathrm{CCl}_{3} \mathrm{~F}\right.$ and $\left.\mathrm{CCl}_{2} \mathrm{~F}_{2}\right)$ as hydrologic tracers and age-dating tools: The alluvium and terrace system of central Oklahoma: Water Resources Research, v. 28, no. 9, p. 2257-2283.

Chapelle, F.H., 1993, Ground-water microbiology and geochemistry: New York, John Wiley \& Sons, Inc., $424 \mathrm{p}$.

Cushing, E.M., Boswell, E.H., and Hosman, R.L., 1964, General geology of the Mississippi embayment: U.S. Geological Survey Professional Paper 448-B, 28 p.

Fenneman, N.M., 1938, Physiography of eastern United States: New York, McGraw-Hill, 714 p.

Fontes, J.C., 1980, Environmental isotopes in groundwater hydrology in Fritz, Peter, and Fontes, J.C., eds., Handbook of Environmental Isotope Geochemistry: New York, Elsevier, v. 1, p. 75-140.

Frederiksen, N.O., Bybell, L.M., Christopher, R.A., Crone, A.J., Edwards, L.E., Gibson, T.G., Hazel, J.E., Repetski, J.E., Russ, D.P., Smith, C.C., and Ward, L.W., 1982, Biostratigraphy and paleoecology of lower Paleozoic, Upper Cretaceous, and lower Tertiary rocks, in U.S. Geological Survey New Madrid test wells, southeastern Missouri: Tulane Studies in Geology and Paleontology, v. 17 , no. 2 , p. $23-45$.

Graham, D.D., and Parks, W.S., 1986, Potential for leakage among principal aquifers in the Memphis area, Tennessee: U.S. Geological Survey Water-Resources Investigations Report 85-4295, 46 p.

Kingsbury, J.A., 1992, Altitude of the potentiometric surface, September 1990, and historic water-level changes in the Memphis aquifer in the Memphis area, Tennessee: U.S. Geological Survey Water-Resources Investigations Report 92-4002, 1 sheet.

Kingsbury, J.A., and Parks, W.S., 1993, Hydrogeology of the principal aquifers and relation of faults to interaquifer leakage in the Memphis area, Tennessee: U.S. Geological Survey Water-Resources Investigations Report 93-4075, 18 p.

Lovley, D.R., and Woodward, J.C., 1992, Consumption of freons CFC-11 and CFC-12 by anaerobic sediments and soils: Environmental Science Technology, v. 26, p. 925-929.
McDonald, M.G., and Harbaugh, A.W., 1988, A modular three-dimensional, finite-difference, ground-water flow model: Techniques of Water-Resources Investigations of the U.S. Geological Survey, Book 6, Chapter A1, $576 \mathrm{p}$.

Moore, G.K., and Brown, D.L., 1969, Stratigraphy of the Fort Pillow test well Lauderdale County, Tennessee: Tennessee Division of Geology Report of Investigations 26, 1 sheet.

Parks, W.S., 1973, Geologic map of the Southwest Memphis quadrangle, Tennessee: U.S. Geological Survey openfile report, scale 1:24,000.

1978, Geologic map of the Tennessee portion of the Fletcher Lake quadrangle, Tennessee (including portions of adjacent quadrangles to the north, west, and south): Tennessee Division of Geology GM 404-SW, scale 1:24,000.

1990, Hydrogeology and preliminary assessment of the potential for contamination of the Memphis aquifer in the Memphis area, Tennessee: U.S. Geological Survey Water-Resources Investigations Report 90-4092, $39 \mathrm{p}$.

Parks, W.S., and Carmichael, J.K., 1989, Geology and ground-water resources of the Fort Pillow Sand in western Tennessee: U.S. Geological Survey WaterResources Investigations Report 89-4120, 20 p. $1990 \mathrm{a}$, Geology and ground-water resources of the Cockfield Formation in western Tennessee: U.S. Geological Survey Water-Resources Investigations Report 88-4181, 17 p.

$1990 \mathrm{~b}$, Geology and ground-water resources of the Memphis Sand in western Tennessee: U.S. Geological Survey Water-Resources Investigations Report 88-4182, $30 \mathrm{p}$.

Parks, W.S., and Mirecki, J.E., 1992, Hydrogeology, groundwater quality, and potential for water-supply contamination near the Shelby County landfill in Memphis, Tennessee: U.S. Geological Survey WaterResources Investigations Report 91-4173, 79 p.

Plummer, L.N., Prestemon, E.C., and Parkhurst, D.L., 1991, An interactive code (NETPATH) for modeling NET geochemical reactions along a flow PATH: U.S. Geological Survey Water-Resources Investigations Report 91-4078, 227 p.

Pollock, D.W., 1989, Documentation of computer programs to compute and display pathlines using results from the U.S. Geological Survey modular three-dimensional finite-difference ground-water flow model: U.S. Geological Survey Open-File Report 89-381, 188 p.

Richardson, G.J., 1989, A study of potential sources of leakage into the Memphis Sand aquifer beneath the Davis well field in Memphis, Tennessee: Memphis, Tennessee, Memphis State University, unpublished thesis, $82 \mathrm{p}$. 



\section{APPENDIX 1}

Construction diagrams, gamma-ray logs, and lithology from test holes for 12 wells installed in the alluvium and fluvial deposits in the Davis well field area, Memphis, Tennessee 


\section{Appendix 1}

Construction diagrams, gamma-ray logs, and lithology from test holes from 12 wells installed in the alluvium and fluvial deposits in the Davis well field area, Memphis, Tennessee

\section{EXPLANATION}

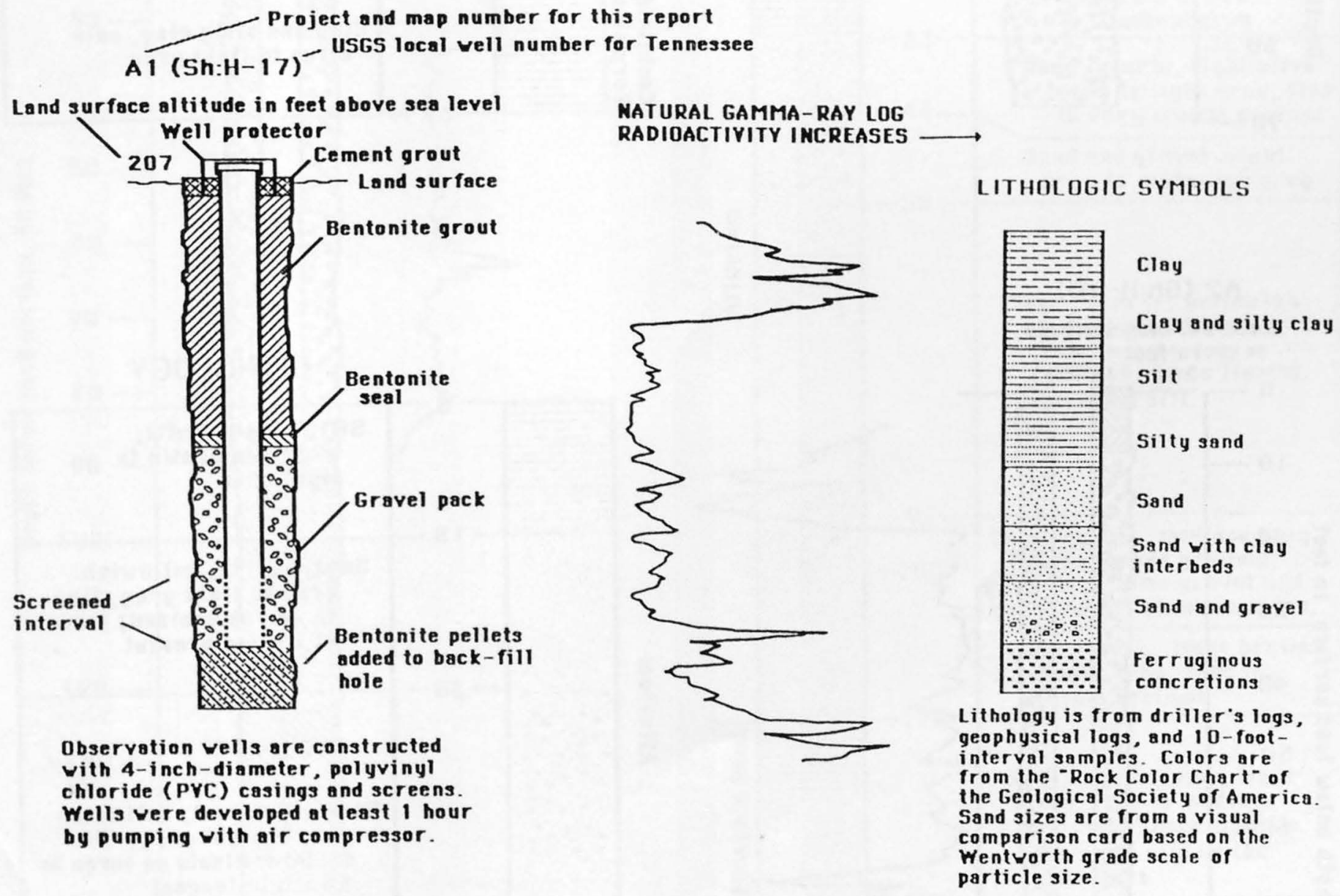



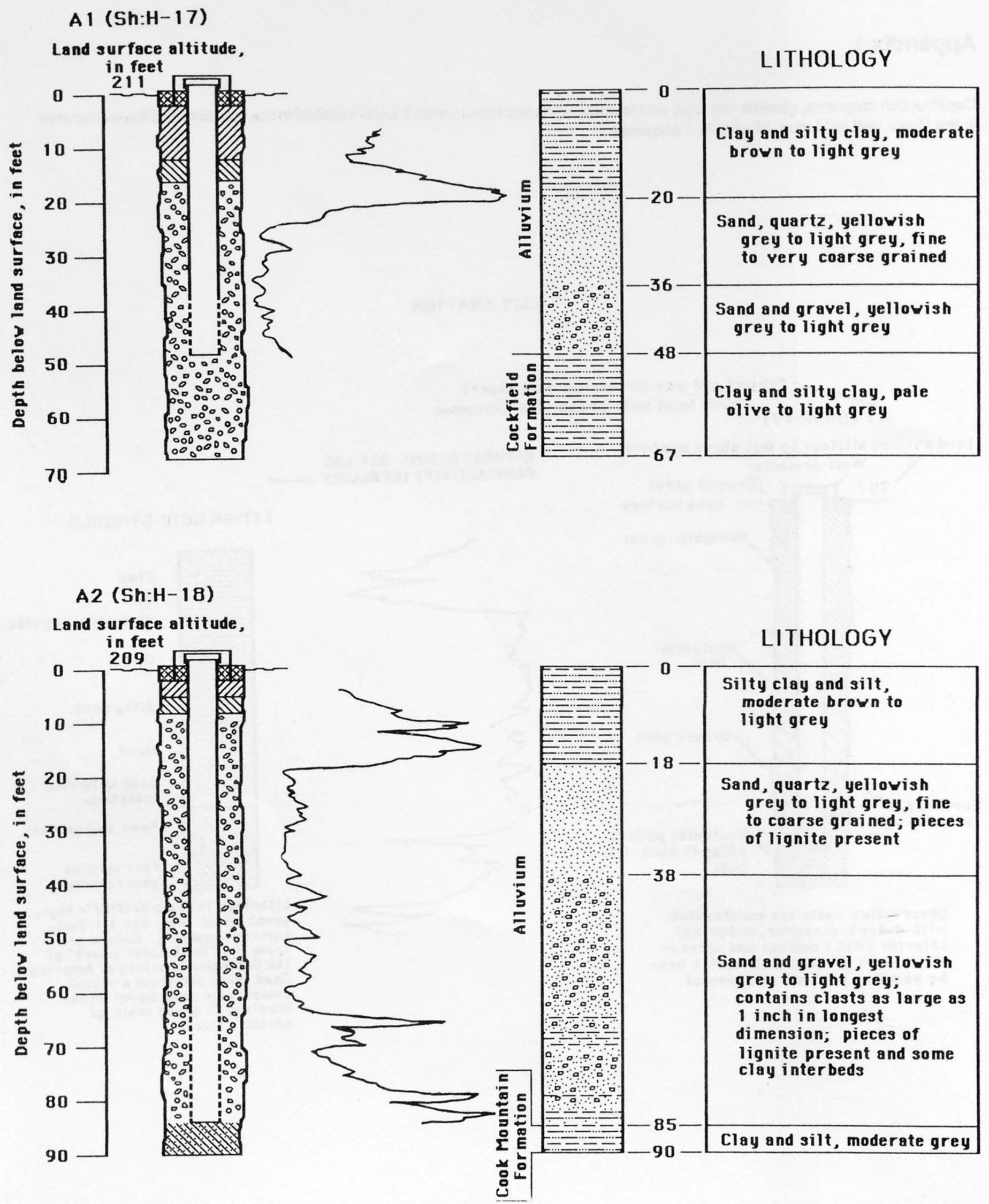

46 Hydrogeology, Ground-Water Quality, and Source of Ground Water Causing Water-Quality Changes in the Davis Well Fleld at Memphis, Tennessee 


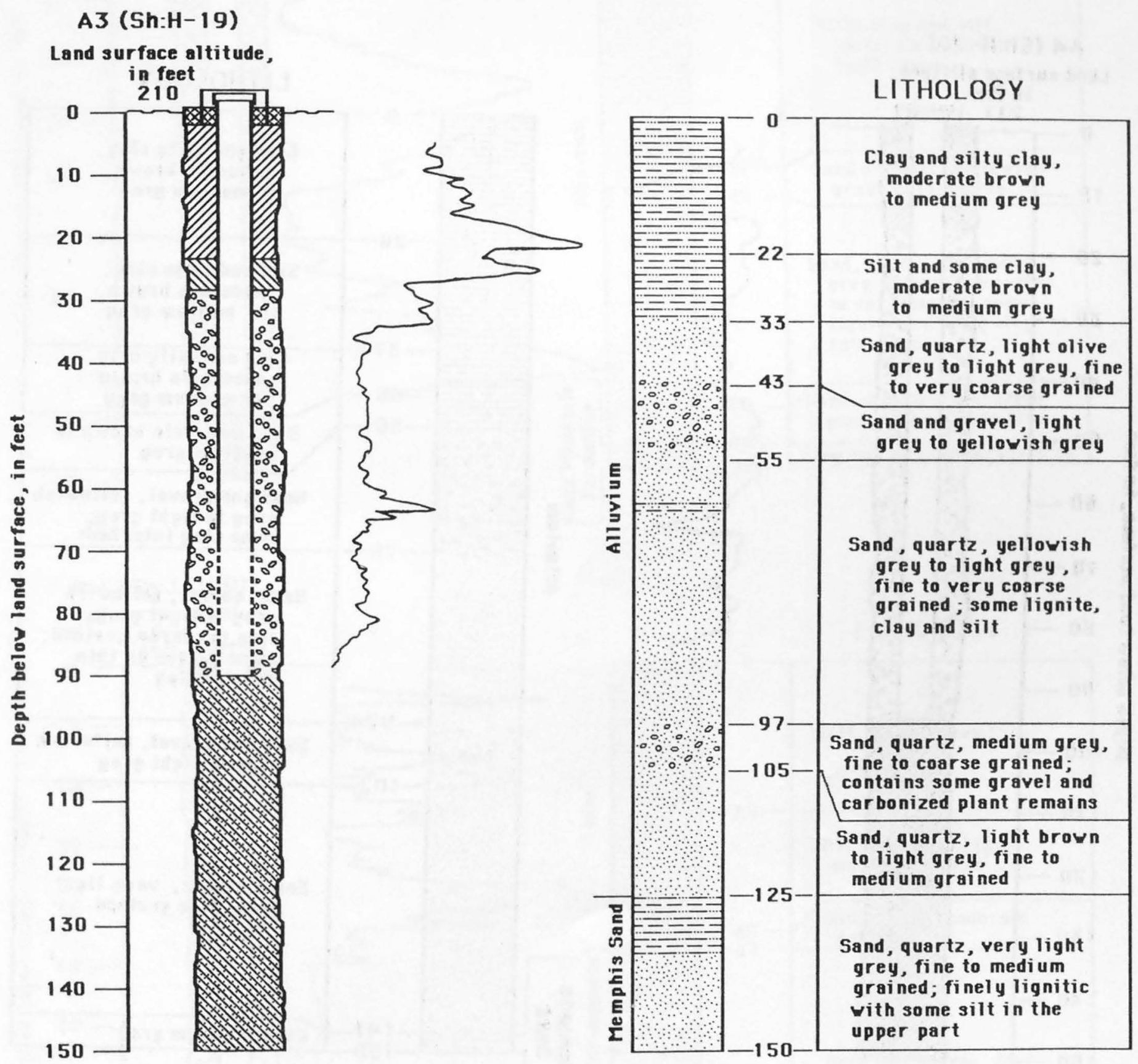


A 4 (5h:H-20)

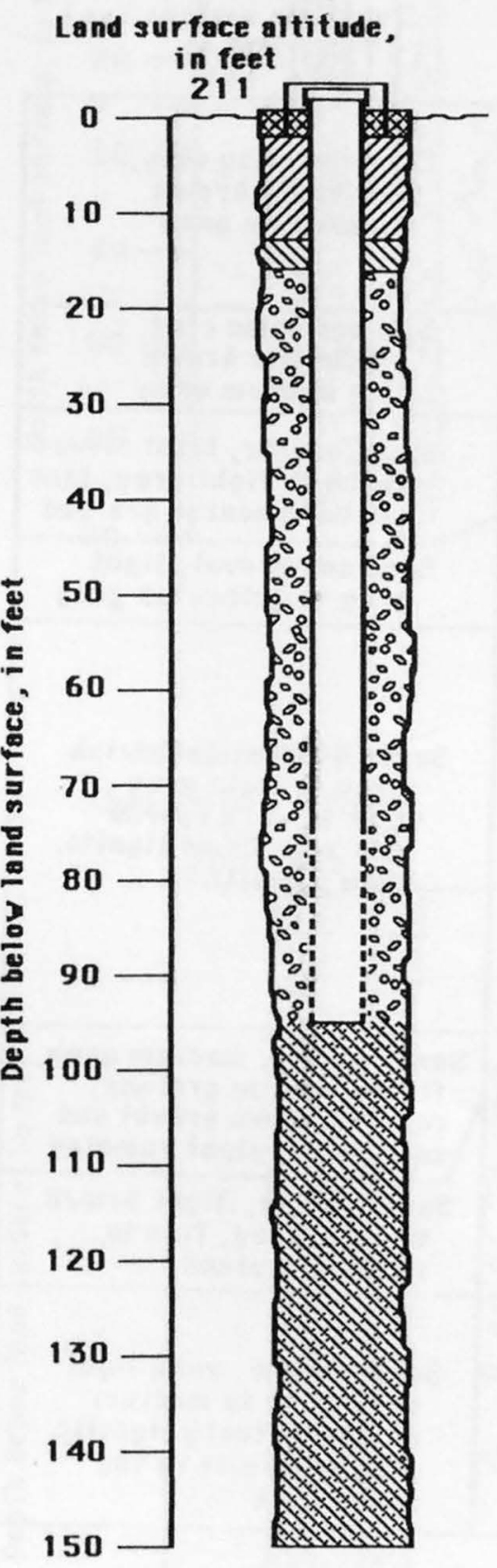

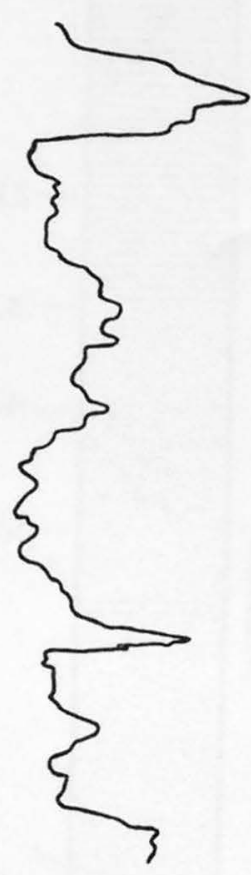

LITHOLOGY

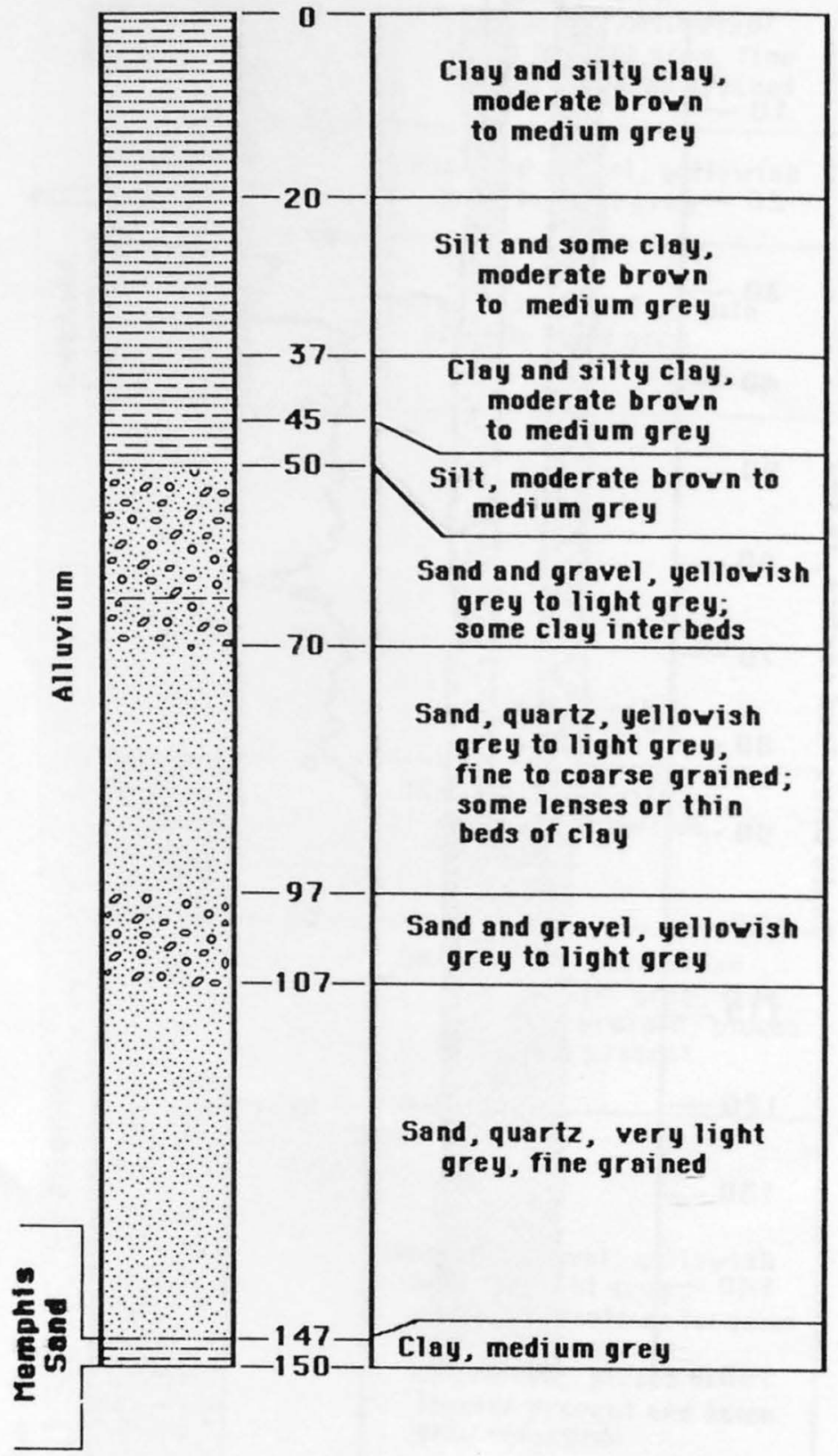



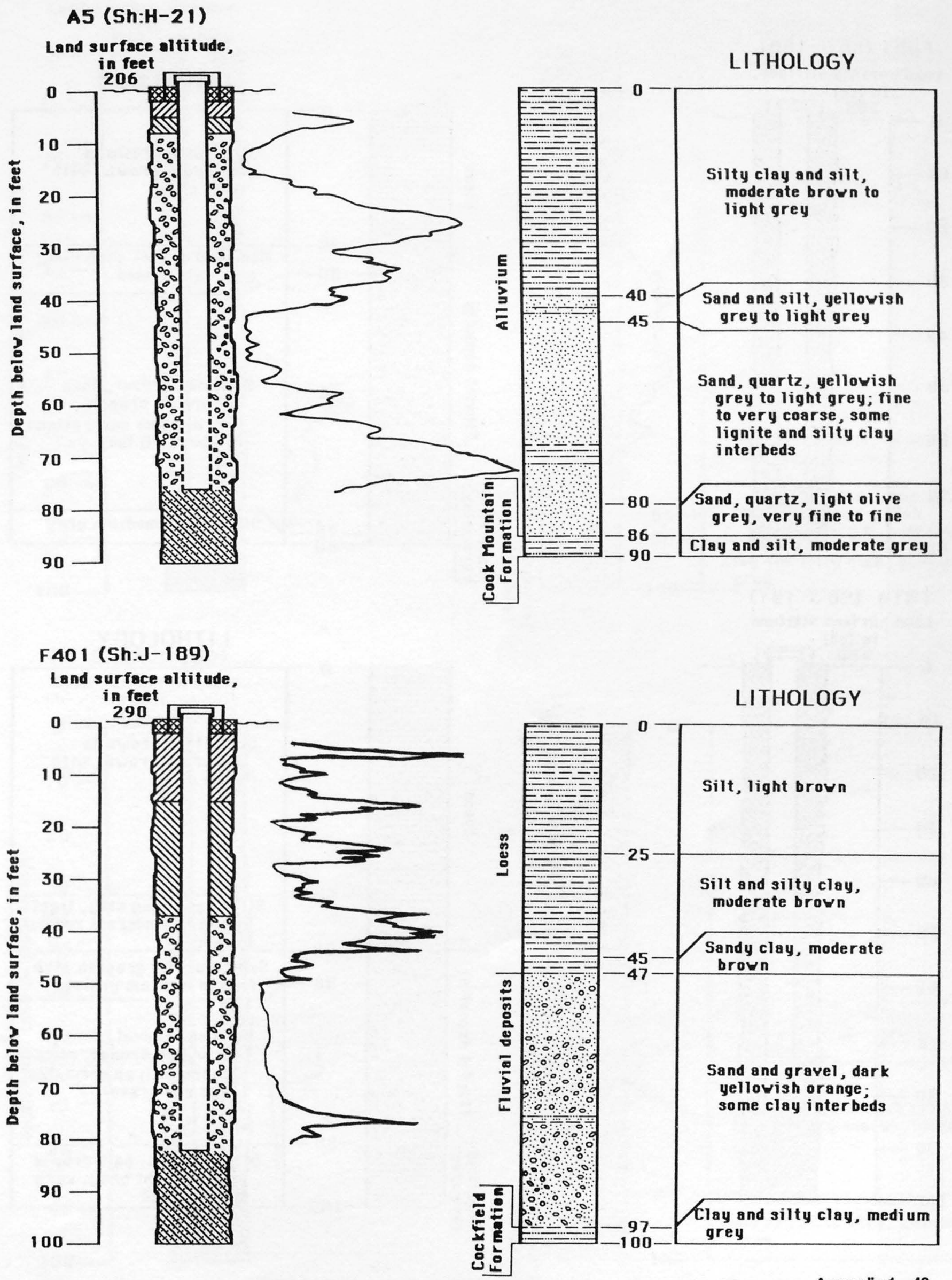
F403 (Sh:J-188)
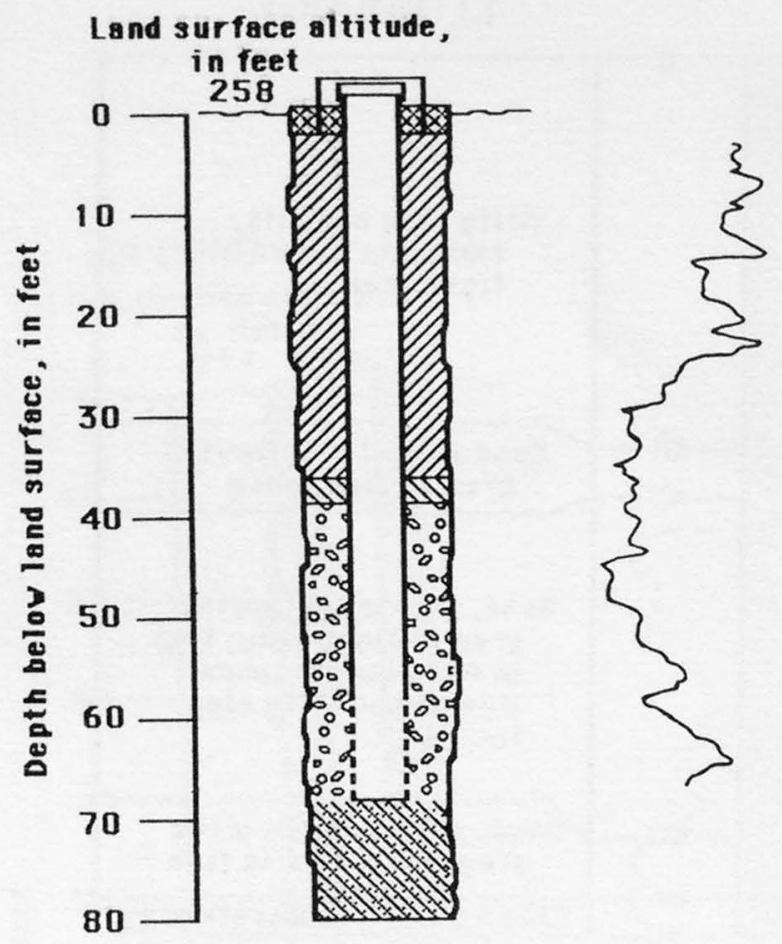

F414 (Sh:J-191)

Land surface altitude,
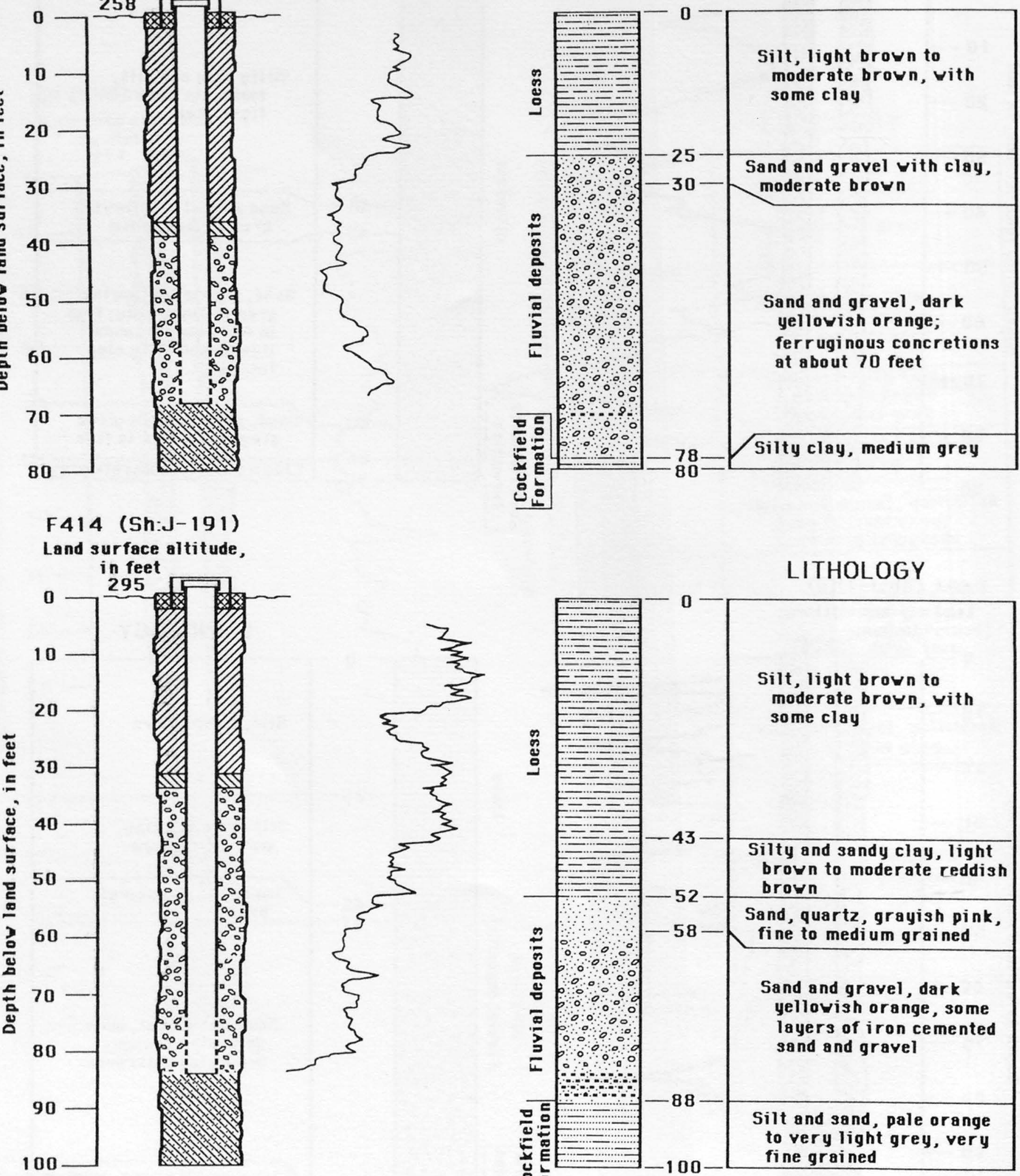

\section{LITHOLOGY}

and and gravel, dar yellowish orange;

retions at about 70 feet

\section{LITHOLOGY}

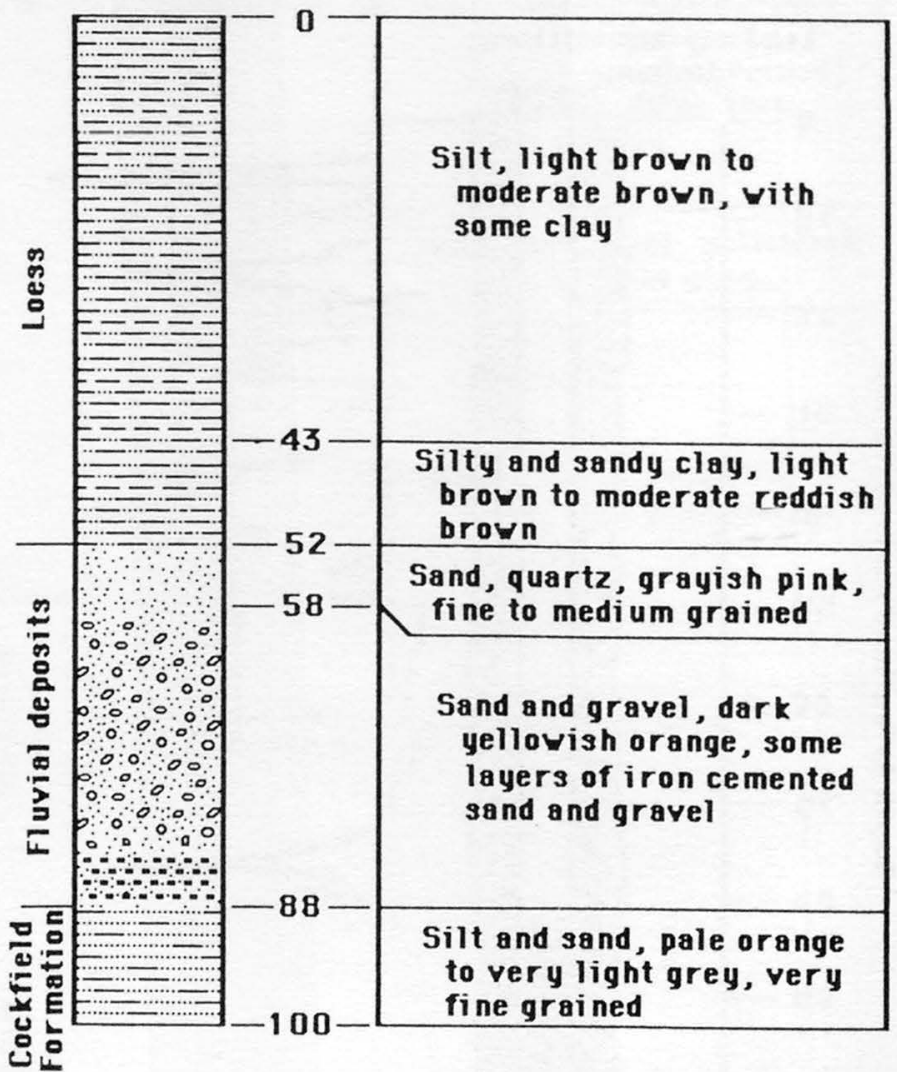

50 Hydrogeology, Ground-Water Quality, and Source of Ground Water Causing Water-Quality Changes in the Davis Well Fleld at Memphis, Tennessee 
F415 (Sh:H-23)

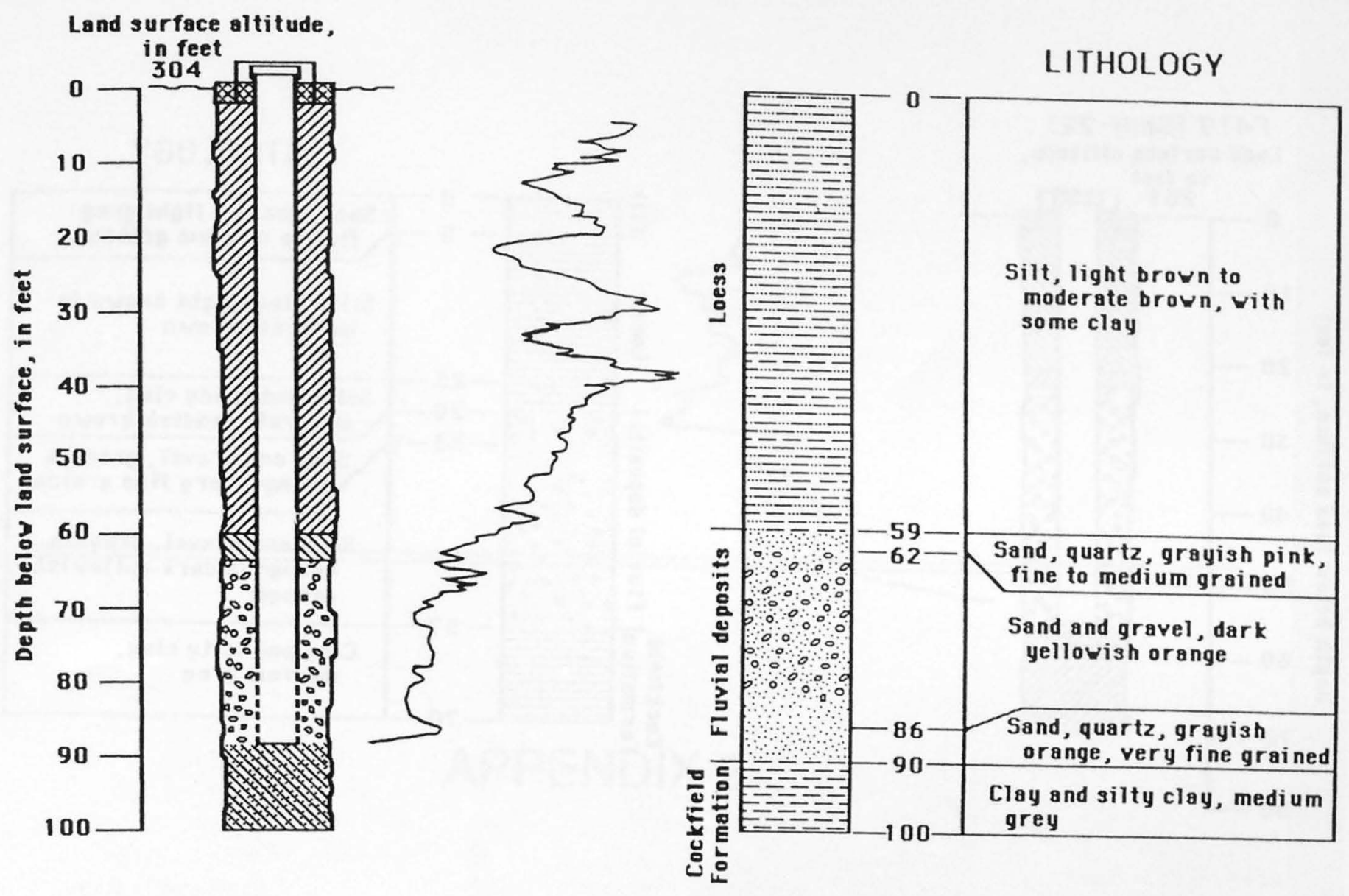

F416 (Sh:J-190)
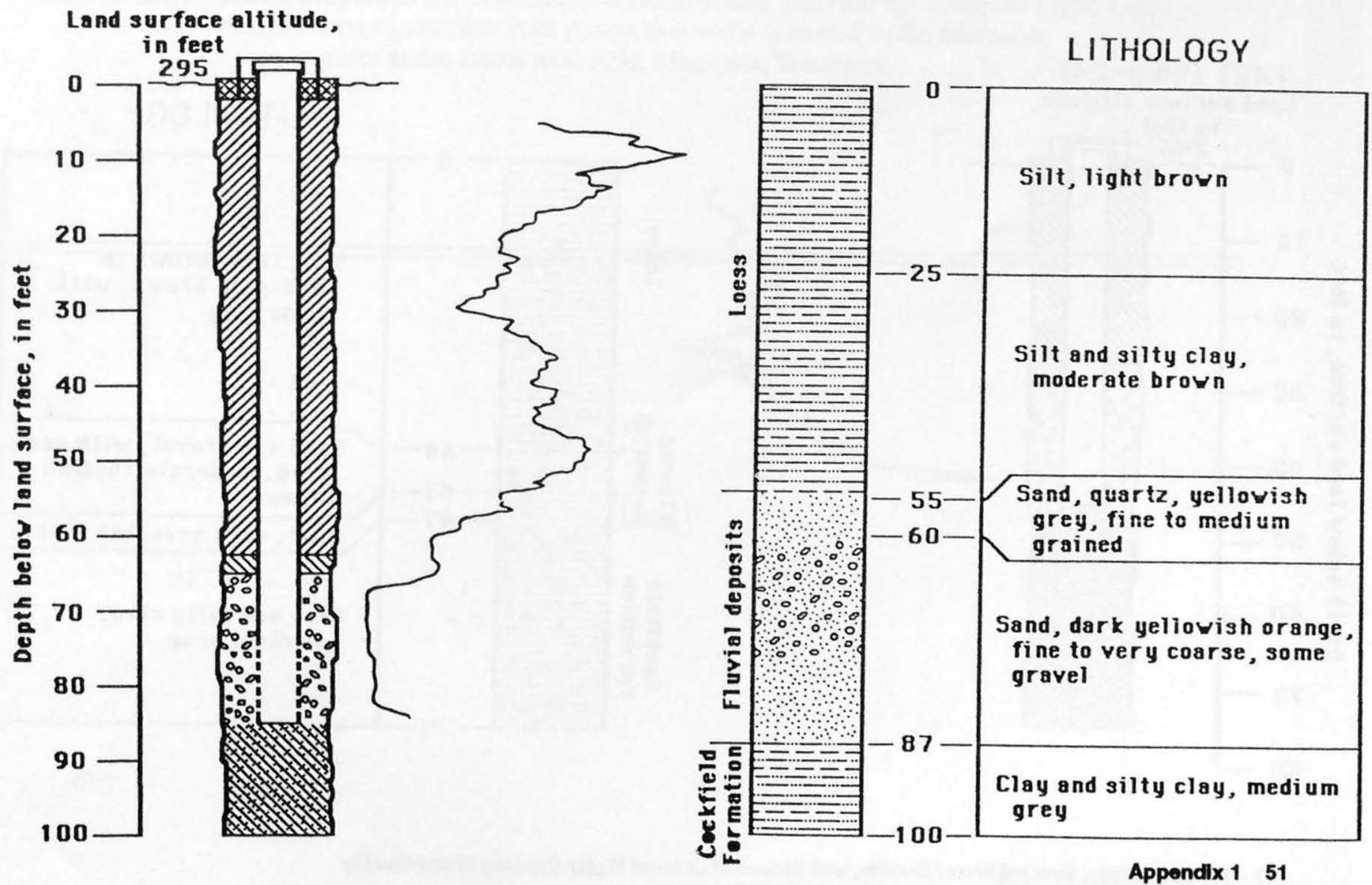
F419 (Sh:H-22)
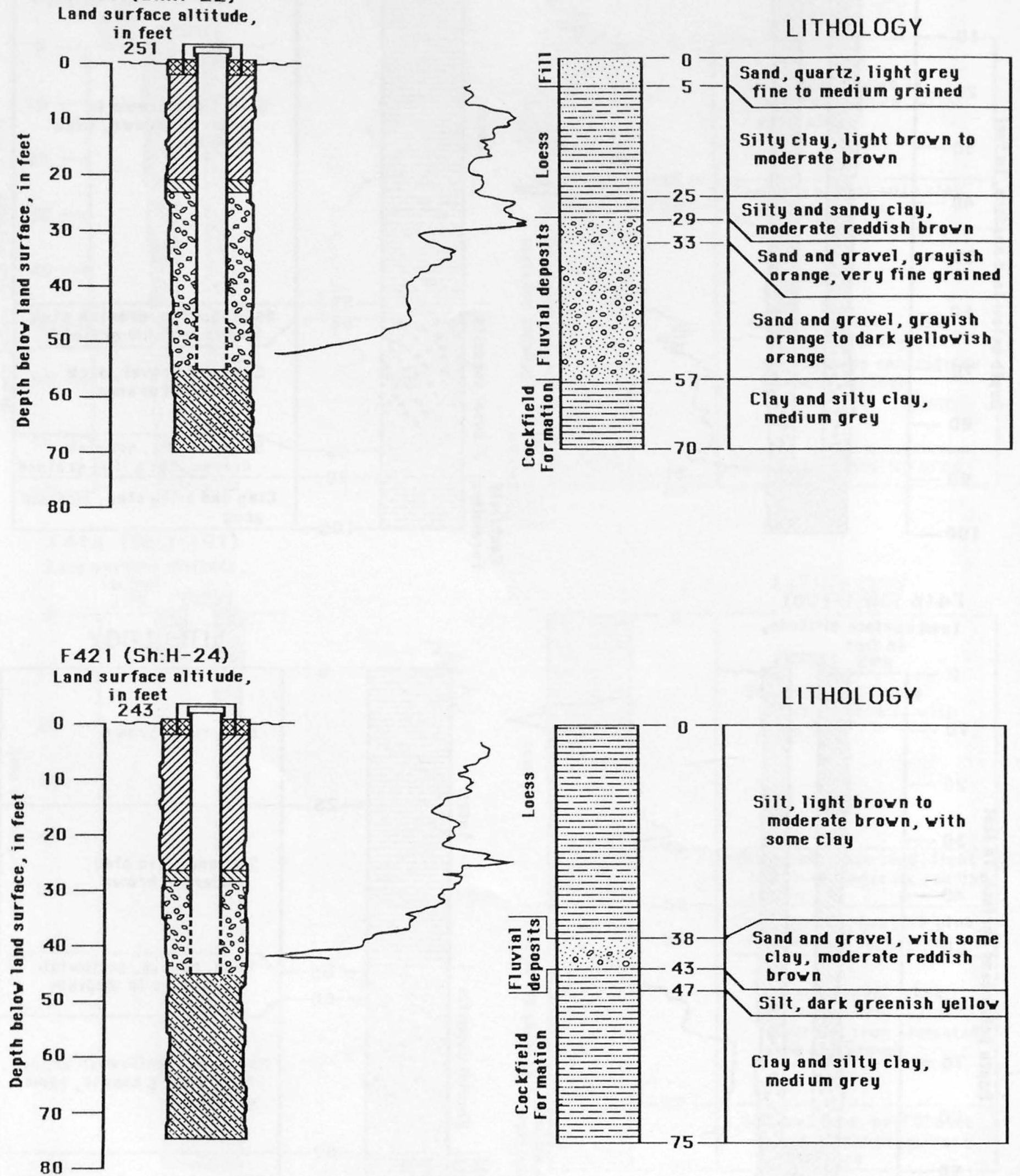

52 Hydrogeology, Ground-Water Quality, and Source of Ground Water Causing Water-Quality Changes in the Davis Well Fleld at Memphis, Tennessee 


\section{APPENDIX 2}

Selected water-quality properties and constituent concentrations analyzed by Memphis Light, Gas and Water Division in samples from production wells screened in the Memphis

aquifer at the Davis well field, Memphis, Tennessee 



\section{APPENDIX 2}

Selected water-quality properties and constituent concentrations analyzed by Memphis Light, Gas and Water Division in samples from production wells screened in the Memphis aquifer at the Davis well field, Memphis, Tennessee, 1972 to 1991

[mg/L, milligrams per liter, $\mu \mathrm{g} / \mathrm{L}$, micrograms per liter, --, indicates no data]

\begin{tabular}{llllll}
\hline $\begin{array}{c}\text { Year } \\
\text { sampled }\end{array}$ & $\begin{array}{l}\text { Hardness, } \\
\text { total }(\mathrm{mg} / \mathrm{L} \\
\text { as } \mathrm{CaCO} /\end{array}$ & $\begin{array}{c}\text { Alkalinity } \\
(\mathrm{mg} / \mathrm{L} \text { as } \\
\left.\mathrm{CaCO}_{3}\right)\end{array}$ & $\begin{array}{c}\text { Sulfate } \\
(\mathrm{mg} / \mathrm{L})\end{array}$ & $\begin{array}{c}\text { Chloride } \\
(\mathrm{mg} / \mathrm{L})\end{array}$ & $\begin{array}{c}\text { Iron } \\
(\mu \mathrm{g} / \mathrm{L})\end{array}$ \\
\hline
\end{tabular}

Well $M 401$

\begin{tabular}{|c|c|c|c|c|c|c|}
\hline 1972 & 78 & 88 & 1.5 & 4.0 & 310 & -. \\
\hline 1973 & 86 & 92 & 2.0 & 4.0 & 310 & -. \\
\hline 1982 & 114 & 116 & 6.0 & 3.0 & 190 & - \\
\hline 1983 & 116 & 117 & 6.5 & 5.0 & 220 & -- \\
\hline 1987 & 132 & 136 & 7.0 & 3.8 & 540 & 57 \\
\hline 1988 & 136 & 134 & 13.5 & 8.0 & 540 & 78 \\
\hline 1989 & 120 & 138 & 7.9 & 4.1 & 330 & 62 \\
\hline 1990 & 140 & 143 & 5.0 & 2.8 & 480 & 82 \\
\hline 1991 & 148 & 160 & 4.3 & 2.8 & 2,140 & 80 \\
\hline
\end{tabular}

Well $M 403$

$\begin{array}{lll}1972 & 70 & 78 \\ 1987 & 50 & 64 \\ 1988 & 66 & 66 \\ 1989 & 64 & 62 \\ 1990 & 62 & 60 \\ 1991 & 76 & 72\end{array}$

\section{5 \\ 3.8 \\ 11.0 \\ 4.2 \\ 2.0 \\ 3.5}

Well M404

1972

1973

1982

1987

1988

1989

1990

1991

1972

1973

1982

1983

1987

1988

1989

1990

1991

72
70
70
66
76
60
66
70

70

88

86

115

112

138

160

154

184

172

$$
\begin{aligned}
& 2.0 \\
& 2.0 \\
& 3.2 \\
& 2.8 \\
& 6.8 \\
& 5.0 \\
& 2.0 \\
& 3.5
\end{aligned}
$$

Well M414

$\begin{array}{rl}94 & 3.0 \\ 95 & 2.0 \\ 112 & 5.6 \\ 119 & 5.9 \\ 150 & 7.0 \\ 158 & 4.0 \\ 144 & - \\ 182 & 8.5 \\ 176 & 5.0\end{array}$

4.0
2.5
5.7
4.5
3.0
3.2

420

320

320

370

390

40

40

42

48

68

35

...

3.5
4.5
3.0
3.0
5.9
3.8
2.3
2.8

4.5

3.0

3.0

5.9

3.8

2.8

3.5

4.0

3.0

4.0

3.3

6.5

2.9

3.0

3.5
470

480

180

330

360

390

330

130

510

910

600

1,000

1,440

1,060

1,080

1,530

110

$$
\begin{array}{r}
-- \\
-- \\
-- \\
36 \\
44 \\
40 \\
55 \\
25
\end{array}
$$


Selected water-quality properties and constituent concentrations analyzed by Memphis Light, Gas and Water Division in samples from production wells screened in the Memphis aquifer at the Davis well field, Memphis, Tennessee, 1972 to 1991--Continued

\begin{tabular}{|c|c|c|c|c|c|c|}
\hline $\begin{array}{l}\text { Year } \\
\text { sampled }\end{array}$ & $\begin{array}{l}\text { Hardness, } \\
\text { total }(\mathrm{mg} / \mathrm{L} \\
\left.\text { as } \mathrm{CaCO}_{3}\right)\end{array}$ & $\begin{array}{c}\text { Alkalinity } \\
(\mathrm{mg} / \mathrm{L} \text { as } \\
\left.\mathrm{CaCO}_{3}\right)\end{array}$ & $\begin{array}{l}\text { Sulfate } \\
\text { (mg/L) }\end{array}$ & $\begin{array}{l}\text { Chloride } \\
\text { (mg/L) }\end{array}$ & $\begin{array}{l}\text { Iron } \\
(\mu \mathrm{g} / \mathrm{l})\end{array}$ & $\begin{array}{c}\text { Barium } \\
(\mu g / L)\end{array}$ \\
\hline
\end{tabular}

Well M415

$\begin{array}{rrrrrr}1972 & 68 & 78 & 2.0 & 3.0 & 220 \\ 1983 & 127 & 110 & 1.5 & 4.0 & 800 \\ 1987 & 126 & 114 & 7.0 & 3.4 & -- \\ 1988 & 130 & 144 & 8.3 & 5.3 & 1,070 \\ 1989 & 140 & 3.6 & 3.8 & 1,540 \\ 1990 & 120 & 126 & 5.0 & 2.5 & 1,010 \\ 1991 & 116 & 128 & 1.7 & 2.8 & 1,230 \\ \end{array}$

1972

1973

1982

1983

1987

1988

1989

1990

1991

1972

1973

1982

1983

1987

1988

1989

1990

1991

$1972 \quad 98$

$1973 \quad 87$

$1982 \quad 115$

$1983 \quad 113$

1987

1988

1989

1990

1991
104

110

106

94

132

134

142

160

113
120

122

116

122

126

\section{Well M416}

94
--
81
82
86
92
86
92
92

2.5
--
2.6
2.1
2.8
5.5
5.2
2.0
1.7

4.0

$-$

$$
3.0
$$$$
3.0
$$

3.1

6.2

3.5

2.3

1.8

Well M4I7

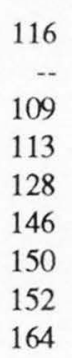

2.5
--
3.2
2.2
3.8
4.8
3.9
3.5
1.7

2.0

850

550

650

3.0

3.0

3.0

7.5

3.6

2.5

4.3

990

1,600

770

1,350

1,860

790

Well M418

$\begin{array}{rr}102 & 2.0 \\ 96 & 2.0 \\ 101 & 5.0 \\ 114 & 5.7 \\ 126 & 2.8 \\ 130 & 6.8 \\ 124 & 3.6 \\ 132 & 2.3 \\ 136 & 3.5\end{array}$

$\begin{array}{rr}530 & -- \\ 380 & -- \\ 320 & -- \\ 670 & -- \\ 1,030 & 86 \\ 690 & 76 \\ 840 & 101 \\ 1,170 & 141 \\ 190 & 48\end{array}$


Selected water-quality properties and constituent concentrations analyzed by Memphis Light, Gas and Water Division in samples from production wells screened in the Memphis aquifer at the Davis well field, Memphis, Tennessee, 1972 to 1991--Continued

\begin{tabular}{llllll}
\hline $\begin{array}{c}\text { Year } \\
\text { sampled }\end{array}$ & $\begin{array}{c}\text { Hardness, } \\
\text { total }(\mathrm{mg} / \mathrm{L} \\
\left.\text { as } \mathrm{CaCO}_{3}\right)\end{array}$ & $\begin{array}{c}\text { Alkalinity } \\
(\mathrm{mg} / \mathrm{L} \text { as } \\
\left.\mathrm{CaCO}_{3}\right)\end{array}$ & $\begin{array}{c}\text { Sulfate } \\
(\mathrm{mg} / \mathrm{L})\end{array}$ & $\begin{array}{c}\text { Chloride } \\
(\mathrm{mg} / \mathrm{L})\end{array}$ & $\begin{array}{c}\text { Iron } \\
(\mu \mathrm{g} / \mathrm{L})\end{array}$ \\
\hline
\end{tabular}

$\begin{array}{rrr}1972 & 90 & 96 \\ 1973 & -- & -- \\ 1982 & 233 & 220 \\ 1983 & 228 & 224 \\ 1987 & 242 & 242 \\ 1988 & 268 & 256 \\ 1989 & 260 & 258 \\ 1990 & 268 & 276 \\ 1991 & 292 & 282\end{array}$

\section{Well M419}

1972

1982

1987

1988

1989

1990

1991

1972

1973

1982

1983

1987

1988

1989

1990

1991

1972

1973

1982

1983

1987

1988

1989

1990

1991

$\begin{array}{rr}70 & 76 \\ 66 & 74 \\ 64 & 70 \\ 102 & 106 \\ 80 & 90 \\ 66 & 76 \\ 98 & 102\end{array}$

62

58

74

79

118

110

110

122

134

78

80

85

121

86

80

80

82

82

68

64

74

85

108

114

122

130

134

76
88
91
88
90
88
80
88
86

76

88

91

88

90

88

80

88

86

$$
\begin{array}{r}
2.0 \\
-- \\
8.0 \\
10.0 \\
6.5 \\
9.0 \\
10.6 \\
18.0 \\
4.3
\end{array}
$$

3.0

200

4.0

8.0

3.1

$--$

4.2

2.5

0.8

2,000

4,380

4,500

3,080

4,410

6,020

4.0

$-$

4.0

8.2

4.8

2.5

3.8

Well M421

Well M422
3.0

3.0

5.0

3.5

10.0

4.3

3.0

4.0

4.0

4.0

$-$

5.0

2.8

7.5

4.3

2.5

3.3
230

710

330

480

450

610

730

890

$-$

$-$

$-$

$-$

97

93

114

120

54

1991


Selected water-quality properties and constituent concentrations analyzed by Memphis Light, Gas and Water Division in samples from production wells screened in the Memphis aquifer at the Davis well field, Memphis, Tennessee, 1972 to 1991--Continued

\begin{tabular}{|c|c|c|c|c|c|c|}
\hline $\begin{array}{l}\text { Year } \\
\text { sampled }\end{array}$ & $\begin{array}{l}\text { Hardness, } \\
\text { total }(\mathrm{mg} / \mathrm{L} \\
\left.\text { as } \mathrm{CaCO}_{3}\right)\end{array}$ & $\begin{array}{l}\text { Alkalinity } \\
(\mathrm{mg} / \mathrm{L} \text { as } \\
\left.\mathrm{CaCO}_{3}\right)\end{array}$ & $\begin{array}{l}\text { Sulfate } \\
\text { (mg/L) }\end{array}$ & $\begin{array}{c}\text { Chloride } \\
\text { (mg/L) }\end{array}$ & $\begin{array}{c}\text { Iron } \\
(\mu g / L)\end{array}$ & $\begin{array}{c}\text { Barium } \\
(\mu g / L)\end{array}$ \\
\hline
\end{tabular}

Well M424

\begin{tabular}{|c|c|c|c|c|c|c|}
\hline 1972 & 50 & 60 & 2.0 & 4.5 & 680 & $\cdots$ \\
\hline 1973 & 52 & 60 & 6.0 & 5.0 & 1,250 & $\ldots$ \\
\hline 1982 & 64 & 65 & 3.2 & 3.0 & 350 & - \\
\hline 1987 & 62 & 76 & 5.0 & 3.5 & 680 & 75 \\
\hline 1988 & 62 & 68 & 10.8 & 7.5 & 600 & 78 \\
\hline 1989 & 66 & 74 & 4.2 & 4.2 & 530 & 76 \\
\hline 1990 & 78 & 68 & 4.5 & 2.8 & 320 & 61 \\
\hline 1991 & 66 & 78 & 3.5 & 3.3 & 650 & 44 \\
\hline \multicolumn{7}{|c|}{ Well M425 } \\
\hline 1972 & 56 & 66 & 2.0 & 4.0 & 790 & - \\
\hline 1982 & 65 & 66 & 3.8 & 3.0 & 350 & - \\
\hline 1983 & 59 & 67 & 4.0 & 7.0 & 570 & - \\
\hline 1987 & 68 & 68 & 6.5 & 2.7 & 670 & 70 \\
\hline 1988 & 62 & 68 & 11.0 & 8.5 & 310 & 70 \\
\hline 1989 & 58 & 72 & 5.7 & 4.0 & 640 & 57 \\
\hline 1990 & 58 & 70 & 5.0 & 2.8 & 740 & 68 \\
\hline 1991 & 76 & 74 & 1.7 & 3.8 & 80 & 36 \\
\hline
\end{tabular}


Parks, Mirecki, and Kingsbury-HYDROGEOLOGY, GROUND-WATĖR QUALITY, AND SOURCE OF GROUND WATER-USGSWRIR $94-4212$ CAUSING WATER-QUALITY CHANGES IN THE DAVIS WELL FIELD AT MEMPHIS, TENNESSEE 